University of Nebraska - Lincoln

DigitalCommons@University of Nebraska - Lincoln

8-3-2017

\title{
Evaluation of simple geochemical indicators of aeolian sand provenance: Late Quaternary dune fields of North America revisited
}

Daniel R. Muhs

Follow this and additional works at: https://digitalcommons.unl.edu/usgsstaffpub

Part of the Geology Commons, Oceanography and Atmospheric Sciences and Meteorology Commons, Other Earth Sciences Commons, and the Other Environmental Sciences Commons

This Article is brought to you for free and open access by the US Geological Survey at DigitalCommons@University of Nebraska - Lincoln. It has been accepted for inclusion in USGS Staff -- Published Research by an authorized administrator of DigitalCommons@University of Nebraska - Lincoln. 


\title{
Evaluation of simple geochemical indicators of aeolian sand provenance: Late Quaternary dune fields of North America revisited
}

\author{
Daniel R. Muhs \\ U.S. Geological Survey, MS 980, Box 25046, Federal Center, Denver, CO 80225, USA
}

\section{A R T I C L E I N F O}

\section{Article history:}

Received 2 January 2017

Received in revised form

2 July 2017

Accepted 6 July 2017

Available online 3 August 2017

\section{Keywords:}

Quaternary

Paleoclimatology

North America

Inorganic geochemistry

Sediment mineralogy

Aeolian sand

Dune fields

K

$\mathrm{Rb}$

Ba

K-feldspar

\begin{abstract}
A B S T R A C T
Dune fields of Quaternary age occupy large areas of the world's arid and semiarid regions. Despite this, there has been surprisingly little work done on understanding dune sediment provenance, in part because many techniques are time-consuming, prone to operator error, experimental, highly specialized, expensive, or require sophisticated instrumentation. Provenance of dune sand using $\mathrm{K} / \mathrm{Rb}$ and $\mathrm{K} / \mathrm{Ba}$ values in K-feldspar in aeolian sands of the arid and semiarid regions of North America is tested here. Results indicate that $\mathrm{K} / \mathrm{Rb}$ and $\mathrm{K} / \mathrm{Ba}$ can distinguish different river sands that are sediment sources for dunes and dune fields themselves have distinctive $\mathrm{K} / \mathrm{Rb}$ and $\mathrm{K} / \mathrm{Ba}$ compositions. Over the Basin and Range and Great Plains regions of North America, the hypothesized sediment sources of dune fields are reviewed and assessed using $\mathrm{K} / \mathrm{Rb}$ and $\mathrm{K} / \mathrm{Ba}$ values in dune sands and in hypothesized source sediments. In some cases, the origins of dunes assessed in this manner are consistent with previous studies and in others, dune fields are found to have a more complex origin than previously thought. Use of $\mathrm{K} / \mathrm{Rb}$ and $\mathrm{K} /$ Ba for provenance studies is a robust method that is inexpensive, rapid, and highly reproducible. It exploits one of the most common minerals found in dune sand, K-feldspar. The method avoids the problem of using simple concentrations of key elements that may be subject to interpretative bias due to changes in mineralogical maturity of Quaternary dune fields that occur over time.
\end{abstract}

Published by Elsevier Ltd.

\section{Introduction}

Dune fields of Quaternary age occupy large areas of the world's arid and semiarid regions, largely (though not entirely) in subtropical deserts but also in rain-shadowed zones of the midlatitudes (Wilson, 1973; Pye and Tsoar, 1990; Cooke et al., 1993; Lancaster, 1989, 1995a; Livingstone and Warren, 1996; Goudie, 2002; Warren, 2013; Lorenz and Zimbelman, 2014). Although there have been many studies of aeolian sand of Quaternary age in both arid and semiarid zones, much of the focus has been on genesis of dune forms, sedimentary structures, and chronology of dune deposition as an indicator of Quaternary paleoclimate. It is interesting that there has been much less work done on understanding dune sediment provenance, with many studies simply assuming an underlying rock or nearby sediment as the primary source or ignoring the issue altogether. Some exceptions to this include studies of the sources of late Quaternary dune sand in northwestern Mexico and the southwestern USA (Muhs et al., 2003; Kasper-Zubillaga et al., 2007; Scheidt et al., 2011), on the Arabian Peninsula (White et al., 2001; Pease and Tchakerian, 2002; Garzanti et al., 2013), in India's Thar Desert (East et al., 2015), in southwestern Africa's Namib sand sea (Garzanti et al., 2012), and in the Sinai/Negev dune fields of Egypt and Israel (Muhs et al., 2013a). Part of the reason that dune provenance studies are uncommon in aeolian geomorphology is that many of the techniques required are time-consuming and prone to operator error (point counts of heavy minerals), experimental and/or highly specialized (remote sensing techniques), expensive (some geochemical techniques), or require sophisticated instrumentation (most isotopic techniques).

Despite the challenges of determining sand provenance, the origin of sediment in a dune field is critical to understanding its evolution. Kocurek and Lancaster (1999) presented the concept of "aeolian system sediment state," which includes, within a dune field, the degree of aeolian activity vs. stability, emphasizing the components of sediment supply, sediment availability, and transport capacity of the wind. Evaluation of the first two of these components requires identification of the sediment source or sources. In a recent review of North American dune fields of late Quaternary age, Halfen et al. (2016) emphasized the importance of sediment supply and sediment availability (as a result of drought episodes) as controls on dune field activity.

Presented here is an exploration and evaluation of the potential 
for using a simple geochemical method in assessing dune field origins. Specifically, the composition of one of the most common minerals found in dune fields, K-feldspar, is tested for utility in provenance studies using $\mathrm{K} / \mathrm{Rb}$ and $\mathrm{K} / \mathrm{Ba}$ values. These geochemical parameters, as indices of K-feldspar composition, are used to assess the origins (sediment sources) of previously studied dune fields of late Quaternary age in the arid portions of the Basin and Range and semiarid parts of the Great Plains provinces of North America (Figs. 1-3).

\section{The problem of changing mineralogy in dune fields}

In a number of previous studies of the origin of North American dune fields, simple comparisons of concentrations of major or trace elements have been made between aeolian sands and candidate source sediments, as proxies for mineralogy (Muhs et al., 1995, 1997a, 1997b, 2000, 2003; Winspear and Pye, 1996; Arbogast and Muhs, 2000; Wolfe et al., 2000; Muhs and Holliday, 2001; Zimbelman and Williams, 2002). The problem with this approach is that dune fields are not static entities from a mineralogical point of view. During periods of stability with a vegetation cover, if climatic conditions are favorable, unstable minerals in dune sands, such as carbonates and feldspars, can be lost through chemical weathering and pedogenesis. During a subsequent period of activity, sands that previously lost easily weathered minerals during a period of stability can then be reworked by the wind, mixing feldspar- and carbonate-poor sands into feldspar- and carbonaterich sands. More importantly for arid and semiarid regions, during periods of dune activity, sand-sized particles of weaker minerals can be reduced to silt sizes through abrasion and ballistic impacts (Marsland and Woodruff, 1937; Kuenen, 1960; Dutta et al., 1993; Cornwall et al., 2015). As a result, the newly formed silt-sized particles can be removed entirely from the dune field by aeolian transport in suspension, usually leaving behind sand relatively enriched in quartz, because quartz is more resistant to mechanical breakdown. This can lead to what is called a mineralogically mature dune field. Mineralogical maturity is a compositional state of a clastic sedimentary body wherein there is a dominance of quartz and an absence or minority of less-resistant particles such as feldspars, carbonates, gypsum, or soft lithic fragments. Sandstones

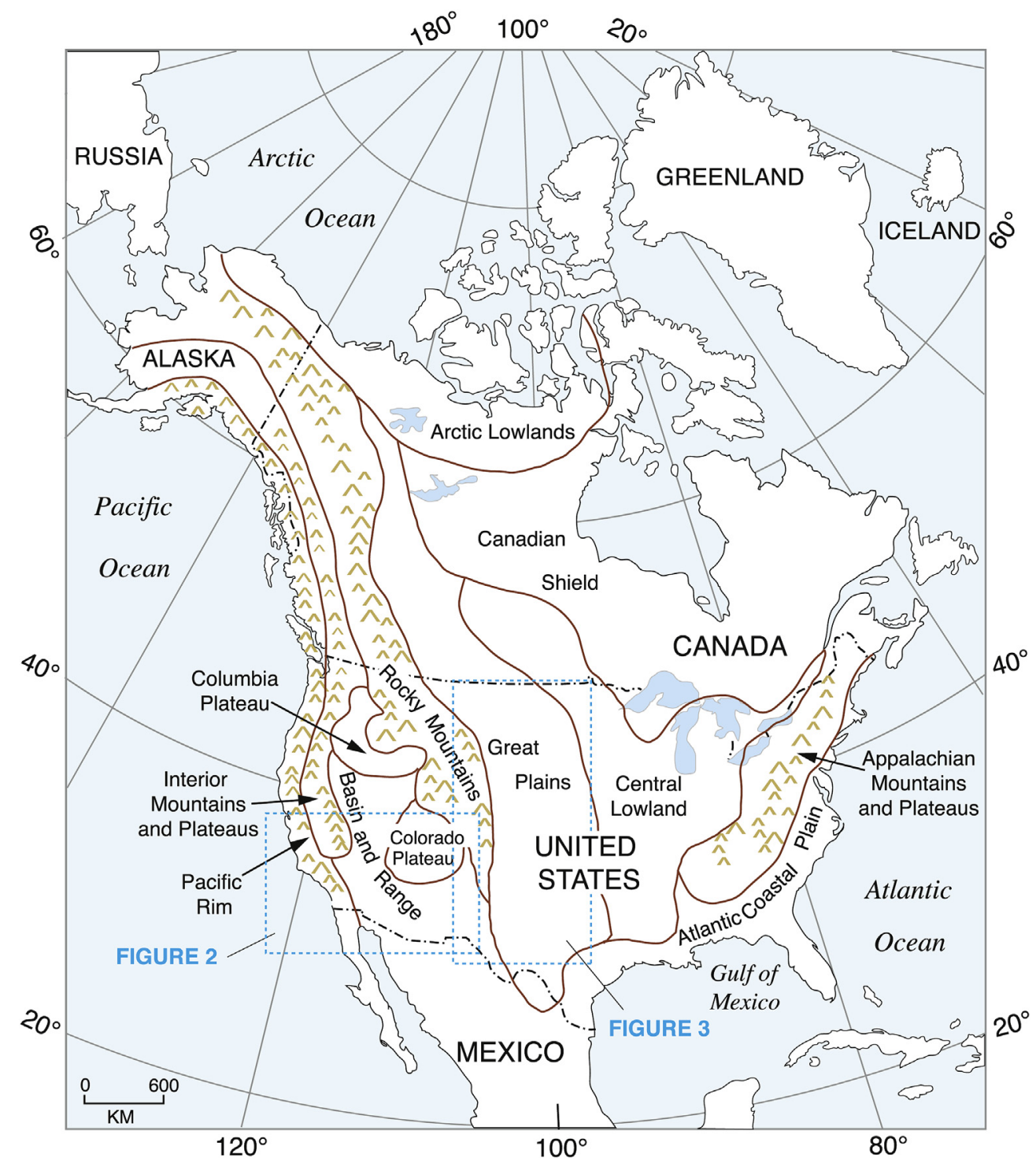

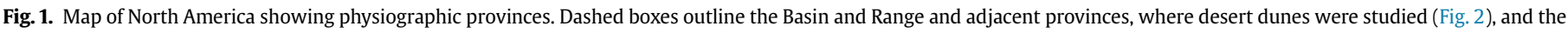
Great Plains, where semiarid dunes were studied (Fig. 3). 

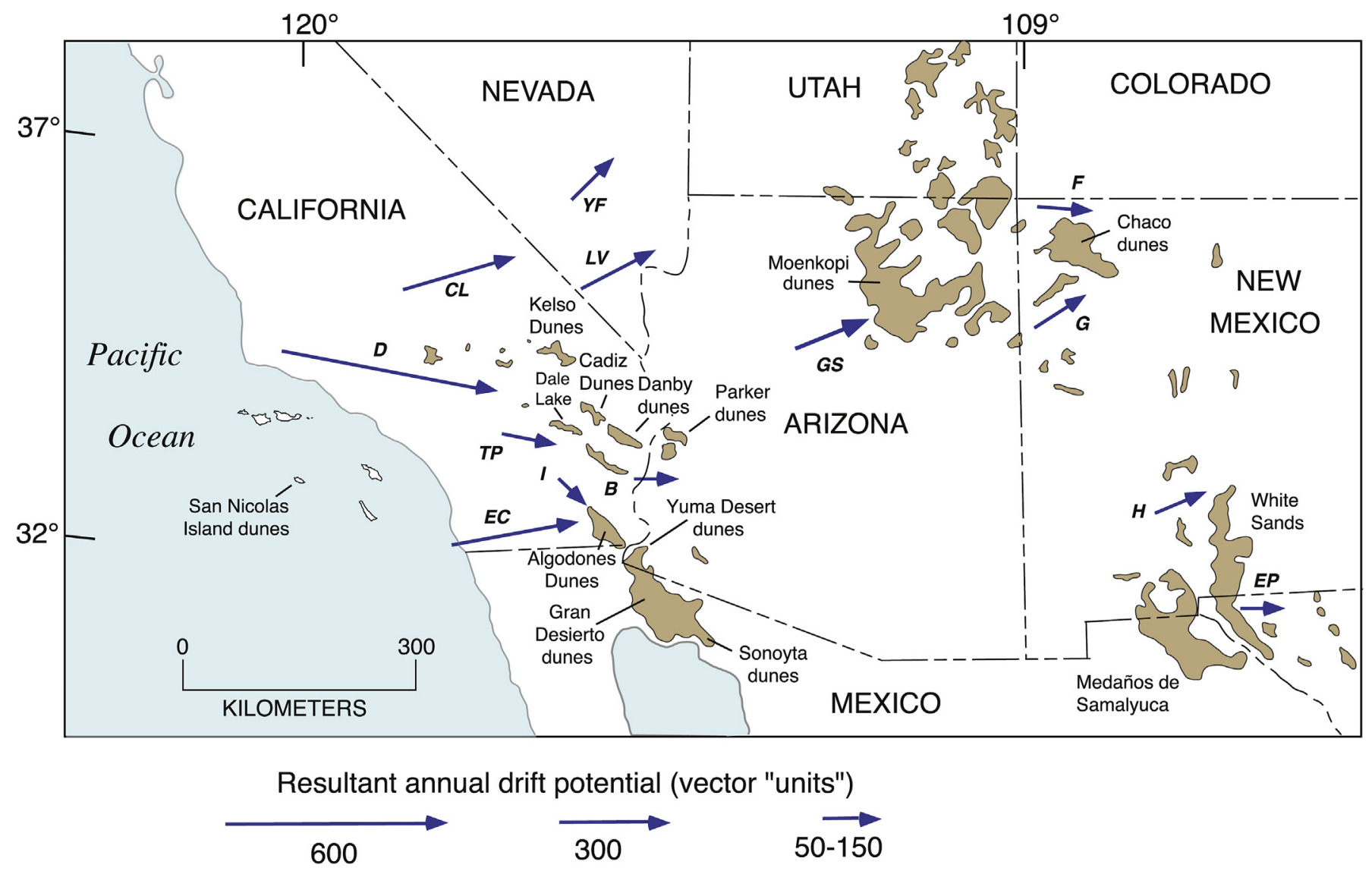

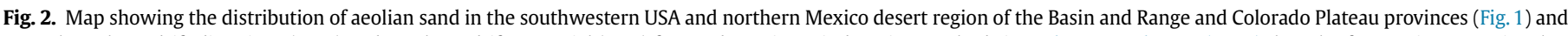

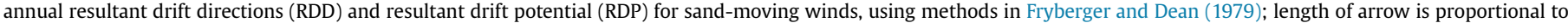

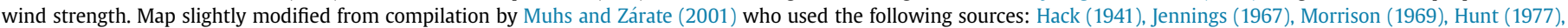

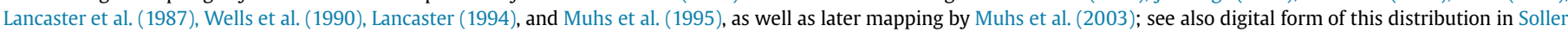

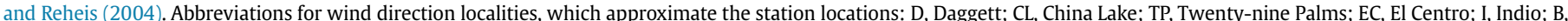

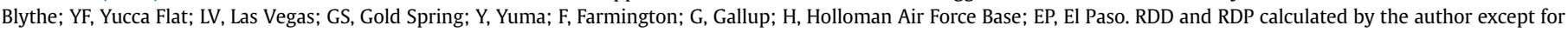
Gold Spring, which is from Helm and Breed (1999) and Holloman Air Force Base, which is from Fryberger and Dean (1979).

that meet this definition are classified as quartz arenites (formerly called orthoquartzites), if they contain at least 95\% quartz (Pettijohn et al., 1973). Thus, aeolian sediments in many of the world's great sand seas of Quaternary age may be properly classified as quartz arenites, a state of maturity that Pettijohn et al. (1973, p. 216) describe as “...the most texturally and compositionally mature of all sands. Some approach the theoretical end point in sand evolution." Dott (2003, p. 387) elegantly described quartz arenites as "...nature's finest distillate-almost as remarkable as a pure single malt Scotch whiskey."

Pettijohn et al. (1973) presented a rigorous method of assessing degree of mineralogical maturity of sandstones geochemically. This procedure uses the logarithm of $\mathrm{Na}_{2} \mathrm{O} / \mathrm{K}_{2} \mathrm{O}$ (a measure of plagioclase to K-feldspar) plotted against the logarithm of $\mathrm{SiO}_{2} / \mathrm{Al}_{2} \mathrm{O}_{3}$ (a measure of quartz to total feldspar). In this method, sandstones that are more mature have lower $\log \left[\mathrm{Na}_{2} \mathrm{O} / \mathrm{K}_{2} \mathrm{O}\right]$ due to plagioclase depletion (assuming that K-feldspar is more resistant) and higher $\log \left[\mathrm{SiO}_{2} / \mathrm{Al}_{2} \mathrm{O}_{3}\right]$ due to overall feldspar depletion. An advantage of the Pettijohn method is that it is very precise and provides a dimensionless comparison of feldspar versus quartz content.

Quaternary dunes worldwide display a wide degree of mineralogical maturity, as illustrated using Pettijohn plots, with a range across the entire spectrum of sandstone types (Fig. 4a). Feldsparrich dunes, such as those in the Taklamakan Desert of China (Yang et al., 2007), fall into the range of graywackes. Somewhat more quartz-rich dunes are found in the Namib sand sea of Namibia, studied by McKee (1982). Samples collected by McKee from this dune field were analyzed by Muhs (2004) for mineralogy. These sands contain both plagioclase and K-feldspar (as well as rock fragments), but quartz is the most important mineral. Goudie et al. (1993) studied dunes of the Great Sandy Desert in Australia and these investigators reported that the sands in these dunes were dominated by quartz. Muhs (2004) studied sands from dunes in this same desert region (those samples shown in Fig. 4a) and reported that only one sample had even the slightest trace of feldspar and all others consisted solely of quartz. McKee and Tibbitts (1964) studied dunes of the Zallaf sand sea of Libya, and Muhs (2004) did mineralogical studies of samples these workers collected. Two samples contain only quartz and others are mostly quartz with only traces of feldspar. Thus, the quartz-dominated dunes of Australia and Libya fall into the range of quartz arenites (Fig. 4a). Intermediate compositions are found in the Sinai dunes of Egypt, the Negev dunes of Israel, and the Rub' al Khali dunes of Saudi Arabia. These intermediate compositions are consistent with the mineralogy of these dunes: Sinai and Negev dunes contain plagioclase and Kfeldspar, but quartz is the most important mineral (see Muhs et al., 2013a; their Fig. 9).

In North America, a similar range of variability is shown for active or Holocene dunes (Fig. 4b). Mojave Desert dunes in California (the Cadiz and Danby dunes and the Dale Lake sand sheet) 


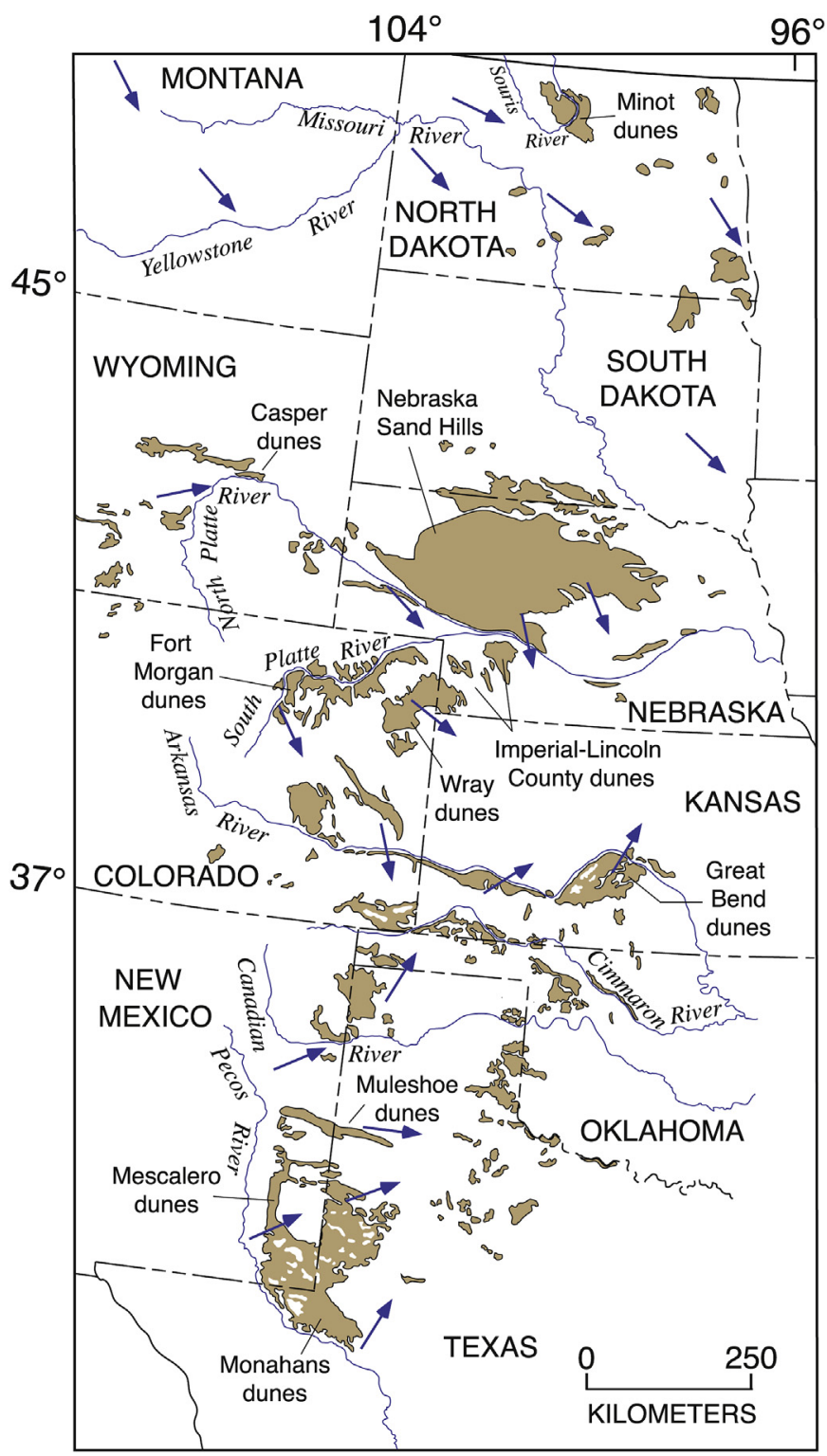

Fig. 3. Map of the Great Plains region in the central USA, showing the distribution of dune fields and annual wind RDD. Aeolian sand distribution modified slightly from compilation in Muhs and Holliday (1995), who used the following sources: Dane and Bachman (1965), Morrison (1969), Westin et al. (1971), Scott (1968, 1978), Sharps (1976, 1980), Love and Christiansen (1985), Swinehart (1990), Kuzila et al. (1990), Ross et al. (1991), Hartman and Scranton (1992), Swinehart et al. (1994a), and Muhs et al. (1996). Most areas mapped here were also field-checked by the author; see also digital form of this distribution in Soller and Reheis (2004). RDD values calculated by the author.

fall into the range of graywackes, whereas many of the dunes in the Monahans dune field of Texas fall into the field of quartz arenites. Dunes in Nebraska and Wyoming have intermediate values. These geochemical plots are consistent with the mineralogy shown in Fig. 5, discussed later.

In some cases, mineralogical maturity is simply inherited from quartz-rich source sediments (see Muhs, 2004; Muhs et al., 2013a for examples), in which case sand composition says little or nothing about dune field history during the Quaternary. In other cases, mineralogical maturity has evolved in a dune field through periods of extended stability (with mineral loss by chemical weathering) or extended activity (with mineral loss by abrasion and ballistic impacts). Thus, the degree of mineralogical maturity
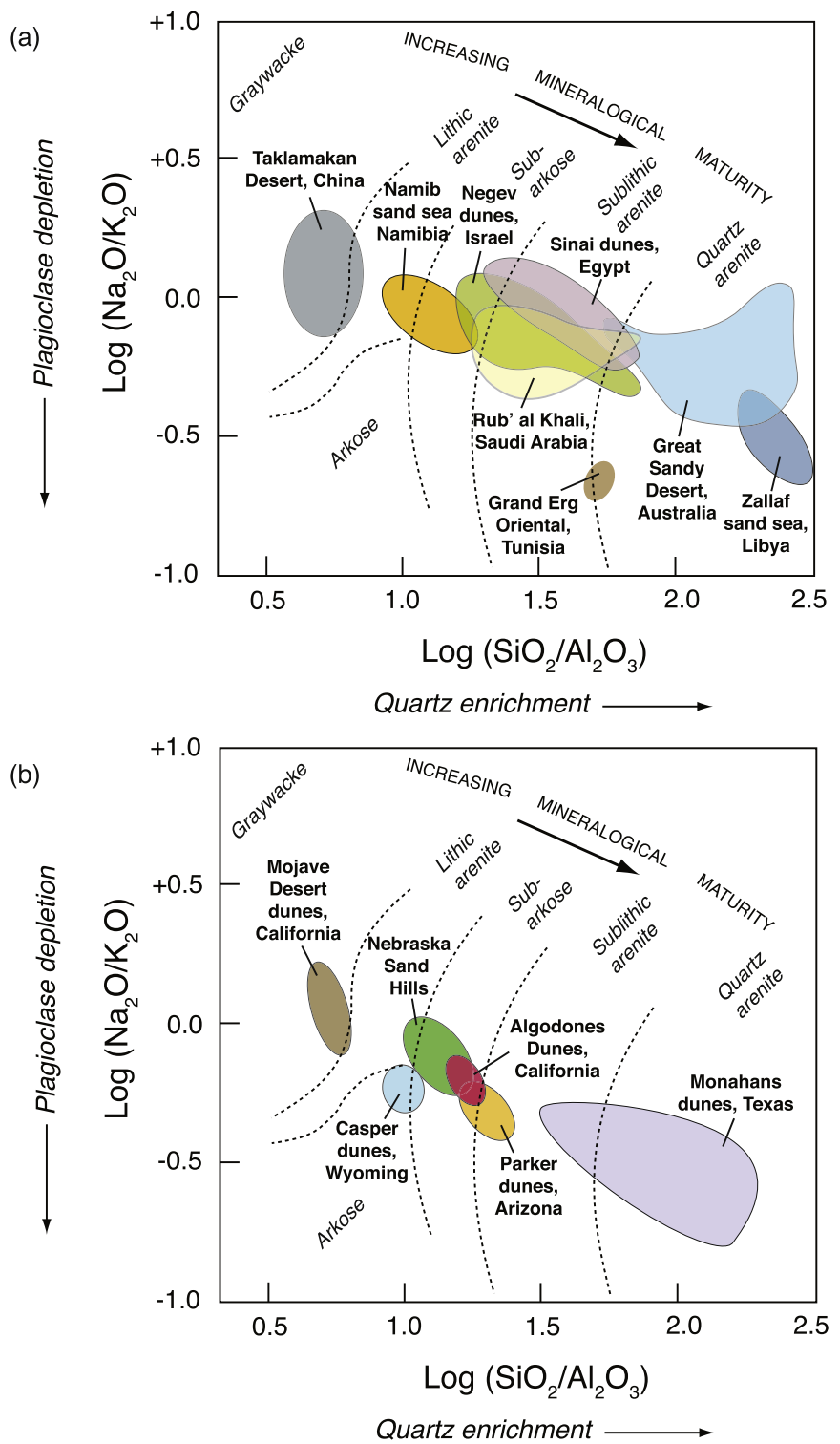

Fig. 4. Mineralogical maturity plots (Pettijohn et al., 1973) for (a) various dune fields of the world and (b) dune fields of North America. Data for the Taklamakan Desert are from Yang et al. (2007); data from the Rub' al Khali are from Moufti (2013); data for the Negev and Sinai dunes are from Muhs et al. (2013a; see also Roskin et al., 2011); data from the Grand Erg Oriental are from the present study. All other dune fields are recalculated from data in Muhs (2004), but all concentrations of major elements and coordinates for sample localities are given in Supplementary Data Table 2. For additional information on the geological setting of samples from dunes in Libya and the Namib sand sea, see McKee and Tibbitts (1964) and McKee (1982), respectively.

can say much about Quaternary dune field history if other information is available. In any case, the dynamic nature of dune field mineralogy makes the simple use of element concentrations or even light mineral abundances to assess source sediments a hazardous practice. For example, given two competing alluvial sources, one of them quartz-rich and the other feldspar-rich, an unwary investigator could infer that a quartz-rich dune field of interest must be derived from the quartz-rich alluvium. However, if the dune field were derived from the feldspar-rich alluvium, but had experienced a long history of feldspar depletion by mechanical breakdown, a quartz-rich dune field would result and the original derivation from the feldspar-rich source may not be apparent. 

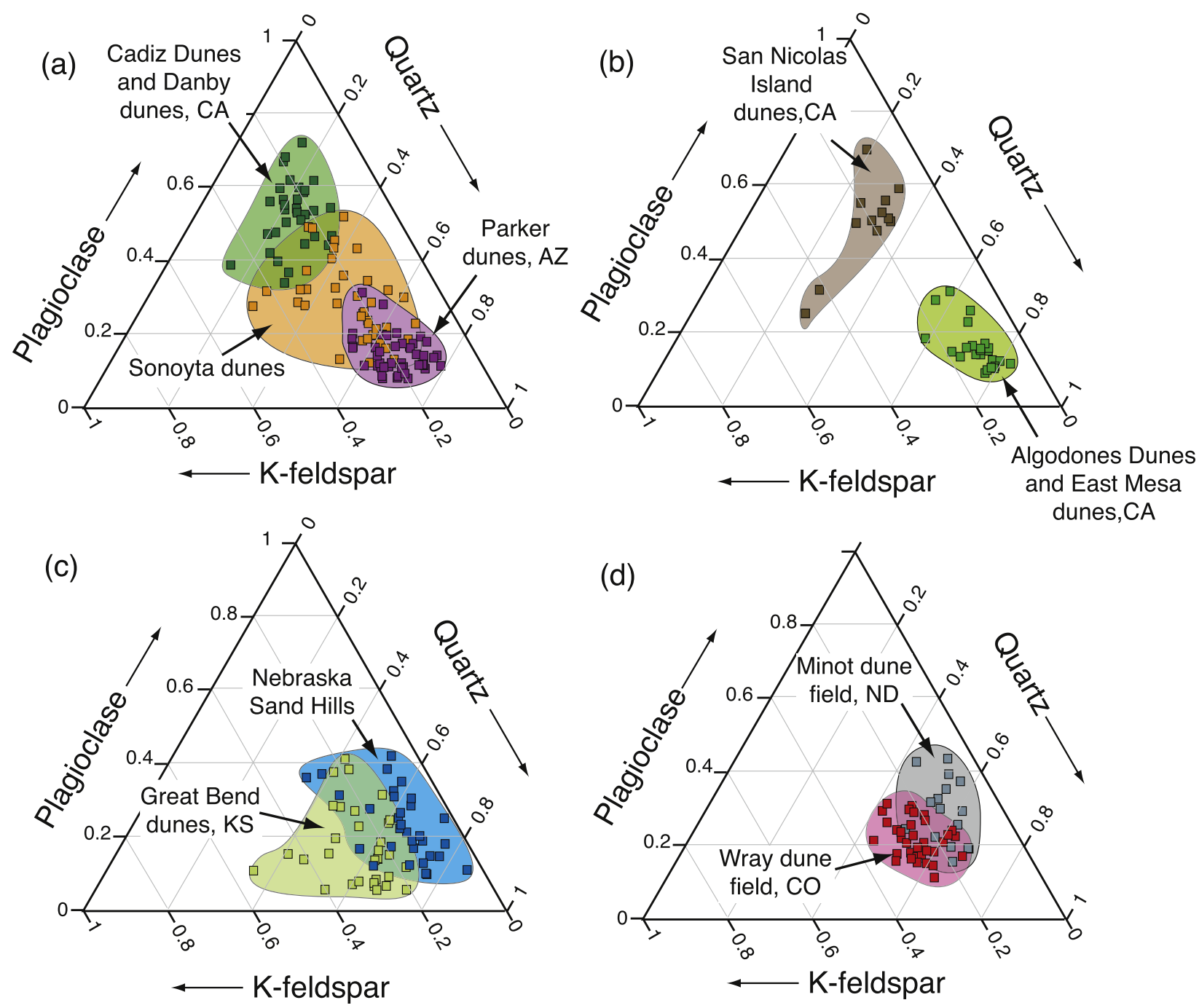

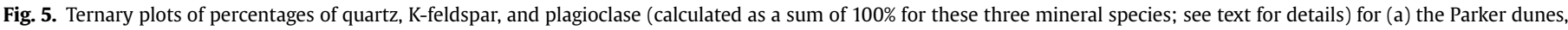

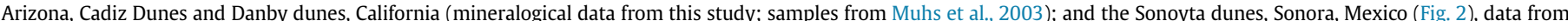

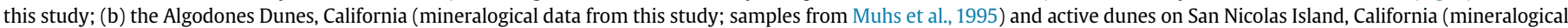

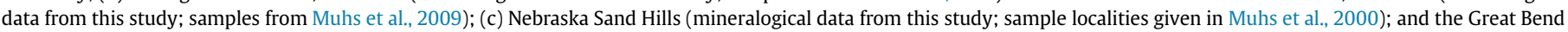

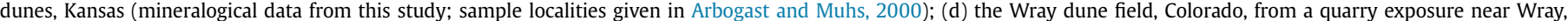

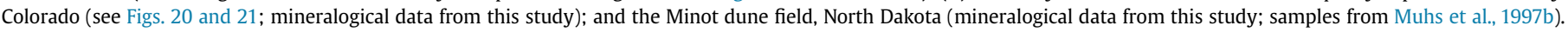

\section{Theory}

In this paper, a method for assessing aeolian sand provenance is explored, without the use of time-consuming, specialized, or expensive techniques. The method uses two major-to traceelement ratios within the same mineral. The fundamental principles behind the method are based on Goldschmidt's (1954) rules of element substitutions in major rock-forming minerals, based on ionic radius and charge, summarized in Mason and Moore (1982). These rules include those of camouflage, capture, and admission. A trace element with the same ionic radius and charge as a major element in a mineral is said to be camouflaged. A good example of camouflage is $\mathrm{Hf}$ substituting for $\mathrm{Zr}$ in zircon. If a trace element has a similar ionic radius, but higher charge than a major element, the trace element is captured into the crystal lattice that hosts the major element. For example, $\mathrm{Ba}^{2+}$ has a similar ionic radius as $\mathrm{K}^{+}$, but with its higher charge, it is captured by K-bearing minerals. Finally when a trace element has a similar ionic radius but lower charge than a major element, or when the trace element has an identical charge, but larger ionic radius than a major element, it is admitted into the crystal lattice. For the latter case, a good example is $\mathrm{Rb}^{+}$ (larger ionic radius) substituting for $\mathrm{K}^{+}$in K-bearing minerals.

Both K-feldspars (microcline and orthoclase) and micas (biotite and muscovite) host $\mathrm{K}$ as a major element. Thus, $\mathrm{Rb}$ and Ba both substitute for K in K-feldspars and micas (Heier and Adams, 1964; Pilkey, 1972). As noted above, due to its higher charge, Ba is captured by K-bearing minerals. Therefore, early formed minerals in a magma tend to be enriched in Ba (although note that Taylor [1965] points out that Ba is not totally depleted in a magma until very late in the differentiation sequence). In contrast, because $\mathrm{Rb}$ is admitted into K-bearing minerals, it tends to be enriched relative to $\mathrm{K}$ in more differentiated minerals (Taylor and Heier, 1960; Taylor, 1965). Within the same plutonic rock, therefore, K-feldspar will have higher $\mathrm{K}$ and lower $\mathrm{Rb}$; biotite will have lower $\mathrm{K}$ and higher $\mathrm{Rb}$ (Lange et al., 1966). There will also be variability in K/Rb in the same minerals with different rock types. For example, in New England, Lange et al. (1966) reported that K-feldspars in granites have $\mathrm{K} / \mathrm{Rb}$ ranging from 108 to 422, quartz monzonites have K-feldspars with 
$\mathrm{K} / \mathrm{Rb}$ ranging from 358 to 477 , and a granodiorite has K-feldspar with a $\mathrm{K} / \mathrm{Rb}$ value of 620 . Biotites in the same rocks studied by Lange et al. (1966) all have lower K/Rb than the associated K-feldspars, but show the same relative differences between rock types. The ranges of $\mathrm{K} / \mathrm{Rb}$ values for $\mathrm{K}$-feldspars and biotites reported by Lange et al. (1966) are similar to those compiled from various sources by Collerson (1975).

For volcanic rocks, Gunn (1965) conducted geochemical studies of Antarctic and New Zealand tholeiites and alkali basalts. In this particular study, both K/Rb and K/Ba data are reported. Gunn (1965) notes that $\mathrm{K} / \mathrm{Rb}$ values for Antarctic dolerites (diorites) range from 198 to 300 and $\mathrm{K} / \mathrm{Ba}$ values range from 20 to 36 , pointing out that these tholeiitic rocks have $\mathrm{K} / \mathrm{Ba}$ values that increase with differentiation, in good agreement with theory.

Reynolds (1972) suggested that K/Rb could be a useful indicator of grade in metamorphic rocks. In support of this, Collerson (1975) reported analyses of metamorphic rocks from Australia that show average $\mathrm{K} / \mathrm{Rb}$ values of 628 (granulite facies), 310 (transitional granulite to amphibolite facies), and 203 (amphibolite facies). The ranges for these rock types are high, however: 244-2293, 120-1583, and 178-604, for granulite, transitional, and amphibolite facies, respectively.

Dune fields in most parts of North America are ultimately derived from sediments composed of a mix of rock types, including plutonic rocks of varying compositions, metamorphic rocks of varying grades, and smaller amounts of volcanic rock fragments and sedimentary rock fragments (that usually were ultimately derived from igneous and metamorphic rocks). Because of the variability of $\mathrm{K} / \mathrm{Rb}$ and $\mathrm{K} / \mathrm{Ba}$ values in different minerals and different rock types, as described above, it is expected that rock residuum, alluvium, lacustrine deposits, glacial deposits, and other sediments that are potential dune sand sources will also have, in aggregate, highly variable $\mathrm{K} / \mathrm{Rb}$ and $\mathrm{K} / \mathrm{Ba}$ values from place to place, depending on source rocks.

In the majority of dune fields, the most common K-bearing mineral is K-feldspar. Although K-feldspar is often reported, micas are rarely reported in dune fields. It is not difficult to understand why this is the case. K-feldspar is approximately seven times as abundant as biotite in granite and it is about five times as abundant as biotite in granodiorite (Wedepohl, 1969, p. 248). These two rock types combined are estimated to comprise $78 \%$ of the upper continental crust of the Earth. Thus, on the surface of the Earth, there is simply less mica available, compared to K-feldspar, for delivery to dune fields from average upper crustal rocks. Furthermore, the platy morphology and relatively soft $(\mathrm{H}=2.5-3.0)$ nature of micas compared to quartz and feldspars $(\mathrm{H}=6-7)$ simply means that biotite and muscovite are much less capable of mechanical survival, as sand-sized particles, in an active dune field.

There are precedents for using ratios of $\mathrm{K}, \mathrm{Rb}$, and Ba for studies of rock origins and sediment provenance. Studies of volcanic rocks and ore deposit hosts have used $\mathrm{K} / \mathrm{Rb}, \mathrm{K} / \mathrm{Ba}$, and $\mathrm{Ba} / \mathrm{Rb}$ as indicators of origins (Hole et al., 1993; McCuaig and Kerrich, 1998; Parker et al., 2005). Muhs et al. (2008, 2013b) showed that $\mathrm{K} / \mathrm{Rb}$ and $\mathrm{Ba} / \mathrm{Rb}$ have the ability to distinguish loess deposits of different provenance in both Alaska and the North American midcontinent. Muhs et al (2017) used $\mathrm{K} / \mathrm{Rb}$ and $\mathrm{K} / \mathrm{Ba}$ to determine the likely source sediments for the Kelso Dunes in the Mojave Desert of California. Except for the most mature aeolian sands (see examples above), most dune fields contain at least some feldspar, both plagioclase and K-feldspar. Unlike individual element concentrations, element ratios such as $\mathrm{K} / \mathrm{Rb}$ and $\mathrm{K} / \mathrm{Ba}$ are insensitive to degree of mineral maturity, as long as at least some K-feldspar has survived. This is commonly the case, because K-feldspars, both microcline and orthoclase, are less prone to chemical weathering than are either $\mathrm{Na}$-plagioclase or $\mathrm{Ca}$ plagioclase (see Birkeland, 1999; White et al., 2008).

\section{Methods}

Aeolian sands and their possible source sediments from a geographically diverse suite of Quaternary dune fields of North America were analyzed for the present work, although all have been previously studied using other methods (Muhs et al., 1995, 1996, 1997a, 1997b, 2000, 2003, 2009; Arbogast and Muhs, 2000; Muhs and Holliday, 2001). Mineralogy of aeolian sand was determined by X-ray diffractometry (XRD) on pulverized, randomly packed powder mounts. Approximate percentages of quartz, Kfeldspar, plagioclase, and calcite were estimated using a method developed by Dr. Amir Sandler of the Geological Survey of Israel (written communication, 9 August 2012). In this method, the following factors are applied to XRD peak heights (two-theta, using $\mathrm{Cu}$ radiation) summed, and calculated as approximate percentages: quartz, 26.6 ${ }^{\circ}$, x 1.0; K-feldspar, $27.4^{\circ}$, x 3.0; plagioclase, $27.8^{\circ}$, x 3.5; and calcite, $29.4^{\circ}$, x 1.1. Crouvi et al. (2009), Enzel et al. (2010), and Muhs et al. (2013a, 2017) have used this method previously and results show good agreement with major element geochemistry.

Aeolian sands from each of the dune fields were analyzed as bulk samples, with no pretreatments other than pulverization. Alluvial and bedrock samples from potential source sediments were pretreated to yield a particle size distribution similar to that of aeolian sand. After disaggregation and removal of coarse gravel, the samples were placed in deionized water, a Na-pyrophosphate dispersant was added, particles in suspension were stirred, and then allowed to sit overnight. After this treatment, the samples were stirred again by ultrasonication and then wet-sieved to remove fine gravel and the coarsest sands. The size fraction chosen for wet-sieving varies from dune field to dune field depending on the particle size of the aeolian sands; see Arbogast and Muhs (2000), Muhs et al. (1995, 1996, 1997a, 1997b, 2003), and Muhs and Holliday (2001) for details. Silt and clay were removed by sieving with either a $53 \mu \mathrm{m}$ or $63 \mu \mathrm{m}$ sieve; no materials finer than $53 \mu \mathrm{m}$ are present in any of the samples. Thus, the final sediment separates contained grains ranging from medium sand to very fine sand, similar to the size range of well-sorted dune sands. Concentrations of $\mathrm{K}, \mathrm{Rb}$, and $\mathrm{Ba}$ and other elements were determined by energy-dispersive X-ray fluorescence (ED XRF) on bulk, pulverized samples, following the methods in Muhs et al. (1995, 1996, 1997a, 1997b). For details on the theory, methods, and sources of error in the ED XRF method, the reader is referred to Johnson and King (1987) and Siems (2002). Based on ED XRF analyses of various geologic materials that are U.S. Geological Survey (USGS) rock standards, standard deviations from counting errors alone for Ba and $\mathrm{Rb}$ are generally $1 \%$ or less (Siems, 2002). In the present study, USGS rock standard GSP-1 was included with each sample batch and resulting concentrations for this standard agree well with published values for most elements (for example, see Muhs et al., 1995; their Table 2). For this rock standard, ED XRF element concentrations agree with published values (Govindaraju, 1989) within $5 \%(\mathrm{~K}), 0.4 \%(\mathrm{Rb})$, and $0.8 \%(\mathrm{Ba})$. Precision for these elements $( \pm 1$ sigma) is $0.9 \%(\mathrm{~K}), 1.2 \%(\mathrm{Rb})$, and $0.8 \%(\mathrm{Ba})$. As noted by Muhs et al. (2017), there can be minor differences in K abundances determined by ED XRF compared to wavelength-dispersive X-ray fluorescence (WD XRF). In particular, concentrations of $\mathrm{K}$ by ED XRF may be biased high by $\sim 5 \%$ of the reported value, based on routine runs of USGS rock standards (e.g., a sample with a $\mathrm{K}_{2} \mathrm{O}$ concentration of $3.5 \%$ by ED XRF might yield a concentration of $3.3 \%$ by WD XRF). Thus, element concentrations determined by WD XRF in the literature may or may not be directly comparable to data presented herein. All data obtained by ED XRF in the present study and coordinates for sample localities are given in Supplementary Data Table 1; for major element concentrations obtained by WD XRF, all data and coordinates for sample localities are given in 
Supplementary Data Table 2.

\section{Study regions}

Inland dune fields of Quaternary age, most of them stabilized by vegetation, are common across much of the western USA and adjacent parts of Canada and Mexico (Fig. 1). Within the USA, these areas of aeolian sand are concentrated in three physiographic regions, the Basin and Range, the Colorado Plateau, and the Great Plains. The southern portion of the Basin and Range province is arid because it is situated under the semi-permanent subtropical highpressure cell of the Northern Hemisphere. In the deserts of the Basin and Range province, dune fields overall are much smaller than in the Great Plains, but active aeolian sand is more common. Active dunes in the southwestern deserts can be found in the Kelso Dunes, Algodones Dunes, Gran Desierto, Medanos de Samalyuca, and White Sands (Fig. 2).

The Great Plains region (Fig. 3) is semiarid because it lies within the rain shadow of the north-south-trending Rocky Mountains, which shield the region to the east from westerly storm tracks. Active aeolian sand in the Great Plains region is limited to the southernmost dunes in Texas and New Mexico and a few other areas where human activities, such as grazing, cultivation, or development of infrastructure have reactivated previously stabilized sand. Dune fields in the Great Plains, despite their limited activity, are spatially more extensive than those in the Basin and Range province, however. The Nebraska Sand Hills dune field, for example, covers $\sim 50,000 \mathrm{~km}^{2}$ (Fig. 3). Although most dunes in the Great Plains and many in the Basin and Range deserts are presently stabilized by vegetation, there is ample evidence that sand in most dune fields has been active within the late Holocene (Ahlbrandt et al., 1983; Swinehart, 1990; Stokes and Gaylord, 1993; Madole, 1995; Loope et al., 1995; Arbogast, 1996; Clarke et al., 1996; Muhs et al., 1996, 1997a, 1997b; Stokes and Swinehart, 1997; Stokes et al., 1997; Wolfe et al., 2000; Holliday, 2001; Lancaster and Tchakerian, 2003; Goble et al., 2004; Mason et al., 2004; Forman et al., 2005; Hall and Goble, 2006, 2015; Miao et al., 2007; Wolfe and Hugenholtz, 2009; Schmeisser et al., 2010; Rich and Stokes, 2011; Halfen et al., 2012, 2016; Schmeisser McKean et al., 2015).

\section{Results}

\subsection{Mineralogy}

Mineralogy of North American dune fields is quite variable, as is apparent from the Pettijohn plots (Fig. 4b). Although all dune fields studied, in both the Basin and Range deserts and Great Plains, are dominated by quartz, K-feldspar and plagioclase, the relative abundances of these three mineral species show a very broad range. In the desert region of the southwestern USA and northwestern Mexico, one can see a continuum in the degree of mineralogical maturity, from the quartz-rich Parker dunes of Arizona, to the Sonoyta dunes of Sonora, to the Cadiz-Danby dunes of southern California (Fig. 5a). A similar difference is seen in the mature Algodones Dunes of southern California compared to the immature coastal dunes of arid San Nicolas Island, California (Fig. 5b). In the Great Plains region, dune fields also show a range in degree of mineralogical maturity, such as the quartz-rich Nebraska Sand Hills compared to the somewhat more K-feldspar-rich Great Bend dunes of Kansas (Fig. 5c). Finally, some dune fields that are widely separated and unrelated to one another geomorphically can have similar compositions, such as the Minot dune field of North Dakota and the Wray dune field of Colorado (Fig. 5d). Importantly, all dune fields studied contain sands that are populated by at least some Kfeldspar, unlike some extremely mature dunes in Africa and
Australia that lack K-feldspar entirely (see examples in Muhs, 2004).

\subsection{Simple tests of the utility of $K / R b$ and $K / B a$ in aeolian sand}

A first step in assessing whether or not $\mathrm{K} / \mathrm{Rb}$ and $\mathrm{K} / \mathrm{Ba}$ are useful indicators of dune sand provenance is to assess whether potential source sediments and dune sands themselves simply show significant differences from region to region. This notion is predicated on the idea that whatever the sources of dunes are, rock types differ from place to place and therefore sediments derived from these rocks also ought to differ from place to place. For example, it has been hypothesized for over a century (see Gilbert, 1896) that sediments of Great Plains rivers are possible sources for dunes in that region. It follows, therefore, that if $\mathrm{K} / \mathrm{Rb}$ and $\mathrm{K} / \mathrm{Ba}$ are to be useful indicators of dune sand provenance in that region, rivers that drain different rock types should have distinctive $\mathrm{K} / \mathrm{Rb}$ and $\mathrm{K} / \mathrm{Ba}$ values in their sand fractions. Presented here are $\mathrm{K} / \mathrm{Rb}$ and $\mathrm{K} / \mathrm{Ba}$ compositions in Great Plains river sands over a north-south distance of $\sim 1500 \mathrm{~km}$, from the Souris River in North Dakota to the Pecos River in New Mexico and Texas (Fig. 6a). Sediments of the Souris River, nearby rivers, and deltaic sediments in the same region are ultimately derived from Precambrian crystalline rocks of the Canadian Shield as well as younger sedimentary rocks (Paleozoic carbonates and Cretaceous shales) that were eroded by the Laurentide ice sheet (see discussion in Muhs et al., 1997b; Wolfe et al., 2000). North Platte River sediments are derived from a wide variety of sources, including Precambrian crystalline rocks of the Medicine Bow Mountains, Laramie Mountains, and Granite Mountains of Wyoming, crystalline rocks from parts of the Front Range and Park Range in Colorado, and also Mesozoic and Cenozoic sedimentary rocks in northern Colorado, southern Wyoming, and western Nebraska. South Platte River sediments are derived primarily from Precambrian crystalline rocks of the Colorado Front Range, with smaller contributions from Phanerozoic sedimentary rocks to the east of these mountains. The Pecos River heads in the Precambrian rocks of the Sangre de Cristo Mountains of northern New Mexico, but much of its sediment is derived from Paleozoic and Triassic sedimentary rocks of eastern New Mexico. These four rivers have sand-sized sediments that show distinctive fields defined by K/Rb and $\mathrm{K} / \mathrm{Ba}$, with very little overlap, indicating that these are effective geochemical indices for differentiating alluvial sources of dune sands (Fig. 6a).

Dune fields also show distinctive $\mathrm{K} / \mathrm{Rb}$ and $\mathrm{K} / \mathrm{Ba}$. In southern California, some dune fields have $\mathrm{K} / \mathrm{Rb}$ and $\mathrm{K} / \mathrm{Ba}$ fields that overlap slightly, but most are distinctive, even when they are not far apart geographically (Fig. 6b). In the Great Plains region, dunes from the northern part of the region (Minot dune field), central part of the region (Wray dune field), and southern part of the region (Mescalero dunes) show compositions that are distinct from one another (Fig. 6c). Even within the central Great Plains region, the Nebraska Sand Hills, Great Bend dunes (Kansas), and Fort Morgan dunes (Colorado) are distinct from one another and show no overlap (Fig. 6d).

This simple exercise shows that North American dune fields and their likely sources can be characterized by distinctive compositions using $\mathrm{K} / \mathrm{Rb}$ and $\mathrm{K} / \mathrm{Ba}$. Further, in some areas where there is, on the basis of the geology, little possibility of anything other than an immediate, local source, $\mathrm{K} / \mathrm{Rb}$ and $\mathrm{K} / \mathrm{Ba}$ are consistent with that obvious source. An example of this is the Minot dune field of North Dakota, found adjacent to the Souris River (Fig. 3). Values of $\mathrm{K} / \mathrm{Rb}$ and $\mathrm{K} / \mathrm{Ba}$ in the Minot dune field (Fig. 6c) overlap the field defined by $\mathrm{K} / \mathrm{Rb}$ and $\mathrm{K} / \mathrm{Ba}$ of Souris River sands (and Pleistocene deltaic sands associated with the same sediment sources) very closely (Fig. 6a). In the following sections, an examination is made of 
(a)

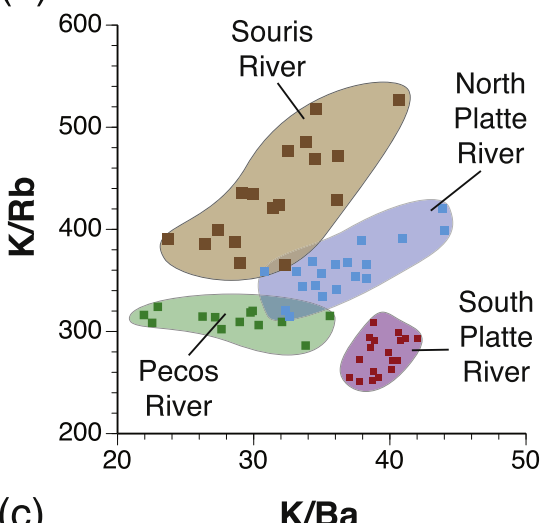

(c)

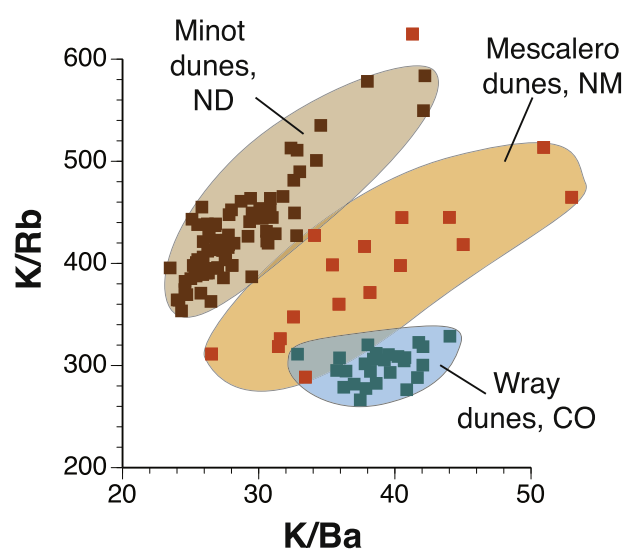

(b)

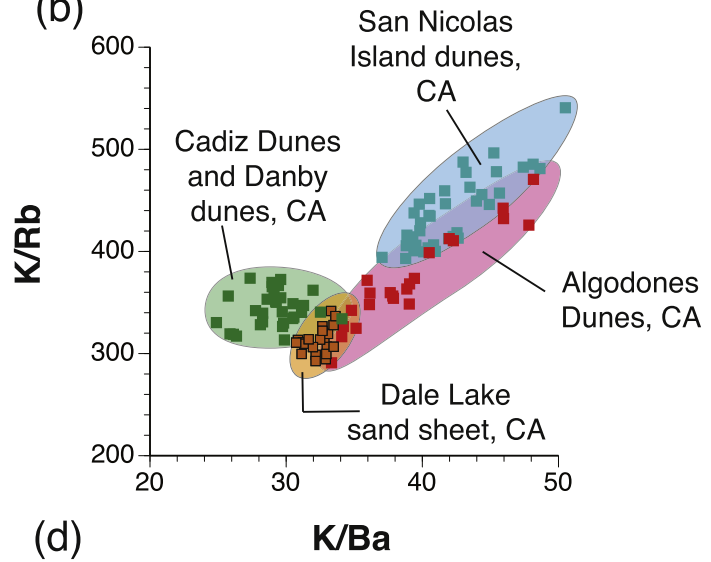

(d)

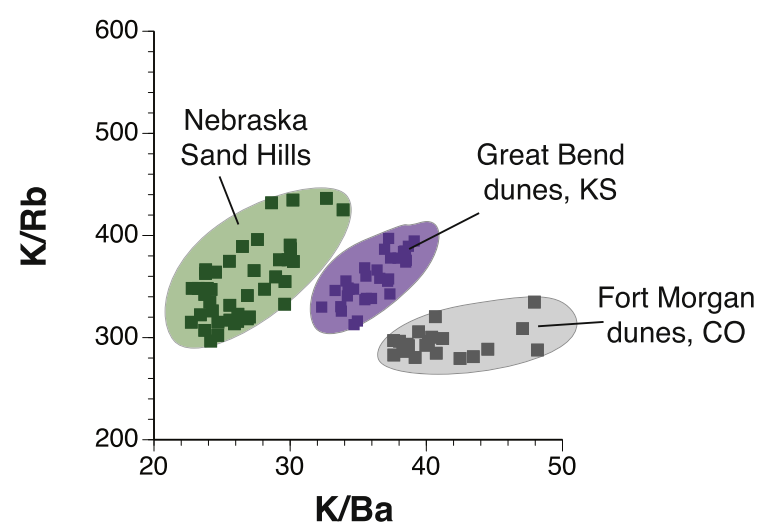

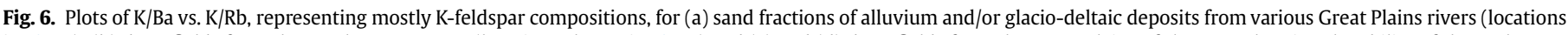

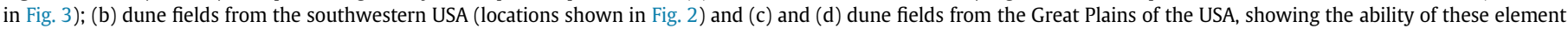
ratios to discriminate aeolian sands of different provenance from one another. CA, California; ND, North Dakota; NM, New Mexico; CO, Colorado; KS, Kansas.

individual dune fields. Hypotheses of their origins are reviewed and new assessments are made using $\mathrm{K} / \mathrm{Rb}$ and $\mathrm{K} / \mathrm{Ba}$.

\subsection{The Algodones Dunes, southern California and the Yuma Desert dunes, southern Arizona}

In the Colorado Desert of southern California, part of the larger Sonoran Desert, the Algodones Dunes are some of the best-known aeolian landforms in North America and the majority of them are fully active (Figs. 7 and 8). To the west of this active dune field is a lesser-known aeolian sand body, East Mesa, that hosts linear dunes and sand sheets that are mostly stabilized by vegetation. Perhaps in part because of the easy accessibility, the origin of these dunes has been debated for more than a century and a half by a number of investigators.

Possible source sediments for the Algodones and East Mesa dunes have contrasting mineralogical compositions. Sands of Whitewater River, to the north of the dune field, are derived from crystalline and metamorphic rocks of the San Bernardino Mountains and thus are rich in feldspars. The same is true of fan sediments derived from the Chocolate Mountains, which are situated to the east of the dune fields. In contrast, Lake Cahuilla shoreline sands, immediately to the west of the dunes, are high in quartz and depleted in feldspars (Muhs et al., 1995). Lake Cahuilla sands are derived from sediments of the Colorado River, which at times in its past flowed into the Salton Trough basin instead of the Gulf of California. Lake Cahuilla was the water body that was created when Colorado River diversions of this sort occurred during the Holocene (Waters, 1983). The high-quartz, low-feldspar composition of Lake
Cahuilla sands is due, therefore, to inheritance from quartz-rich, feldspar-poor sands of the Colorado River. Although it has not been specifically determined, it is likely that Colorado River sands are quartz rich due to sediment derivation from quartz-rich rocks in the lower part of its drainage basin, which includes the Colorado Plateau (Fig. 1). Quartz-rich Colorado Plateau rocks that are drained by the lower Colorado River include the Permian Coconino Sandstone and De Chelly Sandstone, and the Triassic-Jurassic Navajo Sandstone and Kayenta Formation (McKee, 1979).

Examination of $\mathrm{K} / \mathrm{Rb}$ and $\mathrm{K} / \mathrm{Ba}$ values in Algodones and East Mesa dunes and their possible source sediments allows a new, independent assessment of the origin of these dune fields. Algodones sands and East Mesa sands have similar compositions and both show only slight overlap with fan sediments of the nearby Chocolate Mountains and no overlap at all with Whitewater River sands (Fig. 9a and b), indicating that these are not likely important source sediments. However, both dune fields show good agreement with the compositions of both Colorado River and Lake Cahuilla sands (Fig. 9c and d). These observations support an interpretation that the Algodones and East Mesa dunes owe their origins to beach sediments along the Lake Cahuilla shoreline (the immediate source), which were in turn derived from sediments of the Colorado River (the ultimate source).

South of the Algodones Dunes, the Gran Desierto sand sea of the Sonoran Desert is a large dune field, parts of which are also downwind of the Colorado River (Figs. 7 and 8). A number of investigators have shown that much of the sand in this large dune field is derived from the Colorado River (Blount and Lancaster, 1990; Lancaster, 1995b; Kasper-Zubillaga et al., 2007; Scheidt 


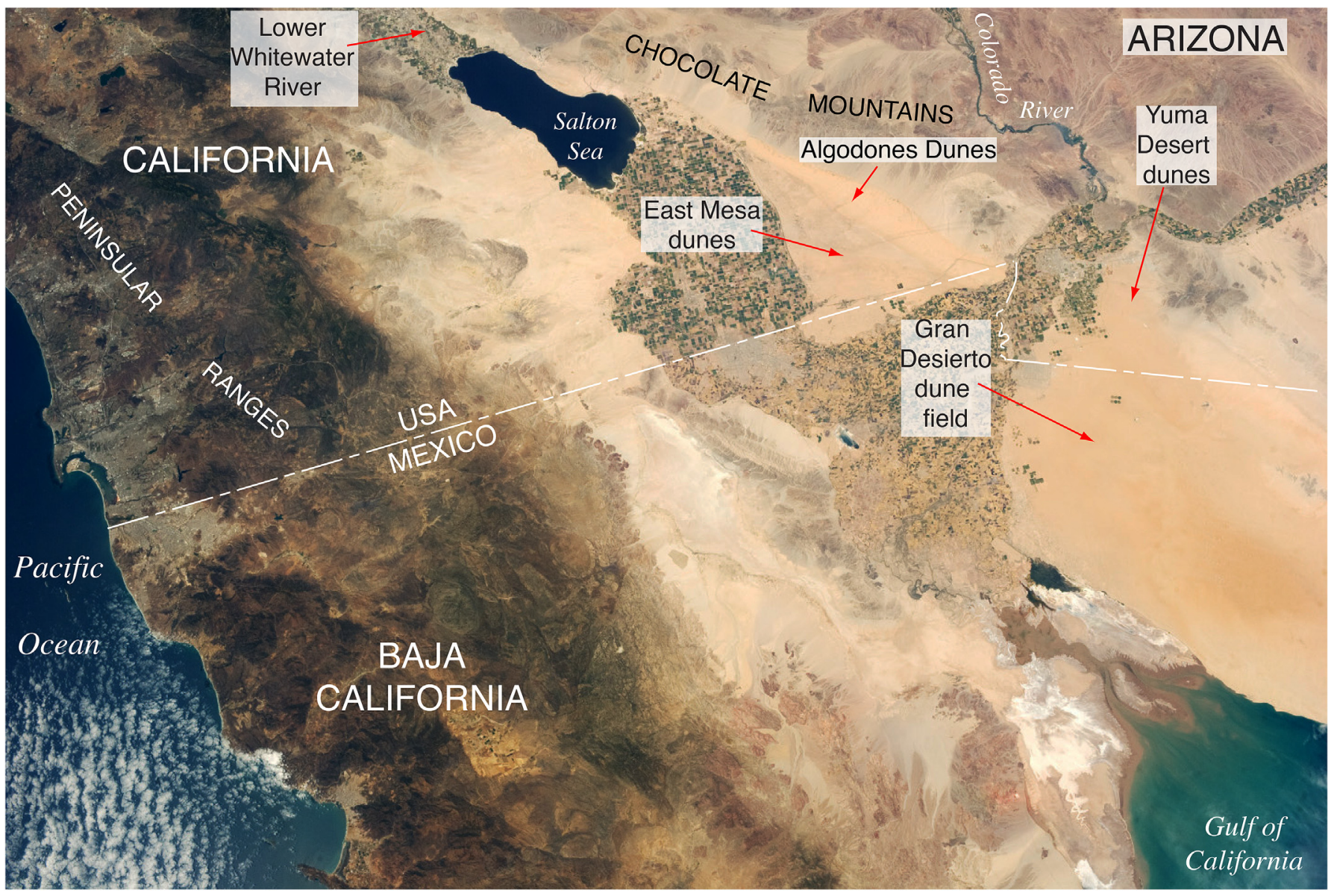

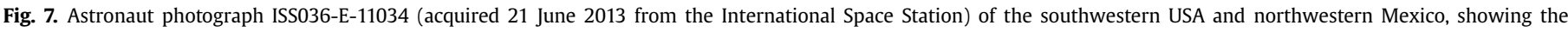

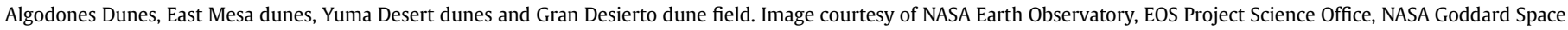
Flight Center.

et al., 2011). Scheidt et al. (2011) also demonstrated that local sources are important around the periphery of this sand sea. The Yuma Desert dunes and the Fortuna dunes a bit farther to the east are essentially northward extensions of the Gran Desierto into southwestern Arizona (Figs. 7 and 8). Landforms composed of aeolian sand in the Yuma Desert consist of both sand sheets and coppice dunes (Muhs et al., 2003). K/Rb and K/Ba values show that the K-feldspar compositions of the Yuma Desert dunes and sand sheets fall within the range of Colorado River sediments and are not significantly different from the Algodones and East Mesa dunes (Fig. 9c and d).

\subsection{Aeolian sand transport pathways in the Mojave and Sonoran Deserts}

In the Sonoran Desert of western Arizona, the Parker dunes, immediately east of the Colorado River (Fig. 10) consist of both linear and parabolic forms and are at least partially active in places. Metzger et al. (1973, p. 26) proposed that the dunes are derived simply from the adjacent Colorado River. However, a concept that has emerged in Mojave and Sonoran Desert dune studies is the presence of distinct sand transport pathways over long (up to $\sim 100 \mathrm{~km}$ or more) distances and involving inter-basin aeolian transport of particles (Zimbelman et al., 1995). One implication in the latter study is that the Parker dunes could be derived from the Cadiz and Danby dune systems, in Mojave Desert basins to the west of the Colorado River (in eastern California) through such a sand transport pathway.

Here, the origin of the Parker dunes is revisited using $\mathrm{K} / \mathrm{Rb}$ and $\mathrm{K} / \mathrm{Ba}$ to test the competing hypotheses of a short-distance Colorado River origin or longer-range derivation from the Cadiz-Danby dune system of California. In addition, in the present analysis, the dune field is examined with respect to its two separate aeolian sand bodies, the Cactus Plain dunes, north of Bouse Wash and La Posa Plain, south of Bouse Wash (Fig. 11). Results of $\mathrm{K} / \mathrm{Rb}$ and $\mathrm{K} / \mathrm{Ba}$ analyses indicate that aeolian sand in the Parker dune field has very little compositional overlap with either the Cadiz or the Danby dunes (Fig. 12a). Both of the latter dune fields have limited ranges of $\mathrm{K} / \mathrm{Rb}$ and $\mathrm{K} / \mathrm{Ba}$ variability and are similar to other dune fields derived from first-cycle granitic alluvium, such as the Dale Lake sand sheet (Tchakerian, 1991), also in the Mojave Desert. The Parker dunes, on the other hand, show a considerable range of variability of $\mathrm{K} / \mathrm{Rb}$ and $\mathrm{K} / \mathrm{Ba}$ values. Dunes in La Posa Plain have $\mathrm{K} / \mathrm{Rb}$ and $\mathrm{K} / \mathrm{Ba}$ values that overlap the range of values for Colorado River sands (Fig. 12b). However, some aeolian sands of the western Cactus Plain fall within the range of Colorado River sands and some fall between the ranges of values for Colorado River sands and Bouse Wash sands (Fig. 12c). In the eastern Cactus Plain, most sands fall between the range of values for Colorado River sands and Bouse Wash sands (Fig. 12d).

\subsection{Dune fields in the Southern High Plains, Texas and New Mexico}

Dunes on the Southern High Plains of Texas and New Mexico 


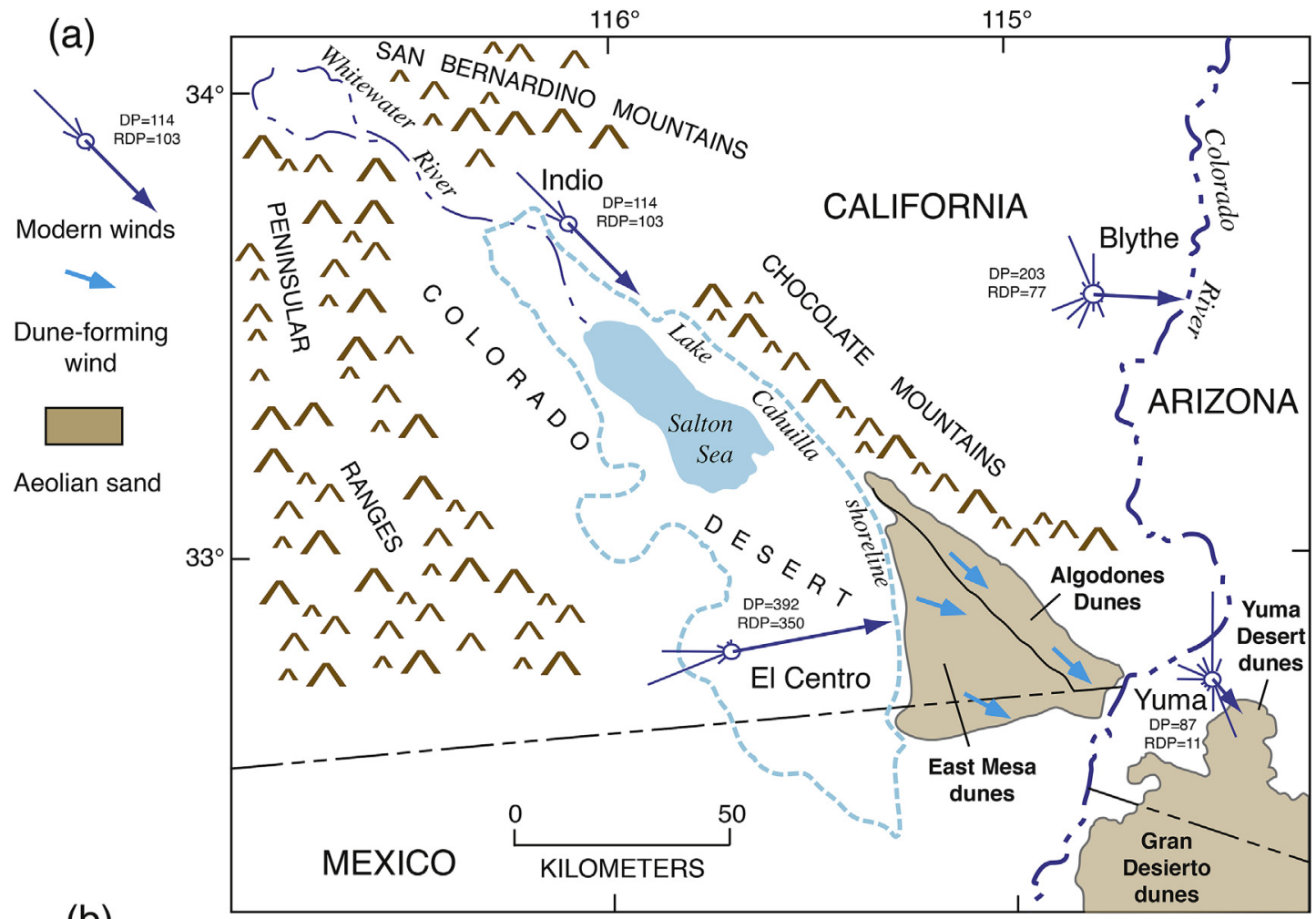

(b)

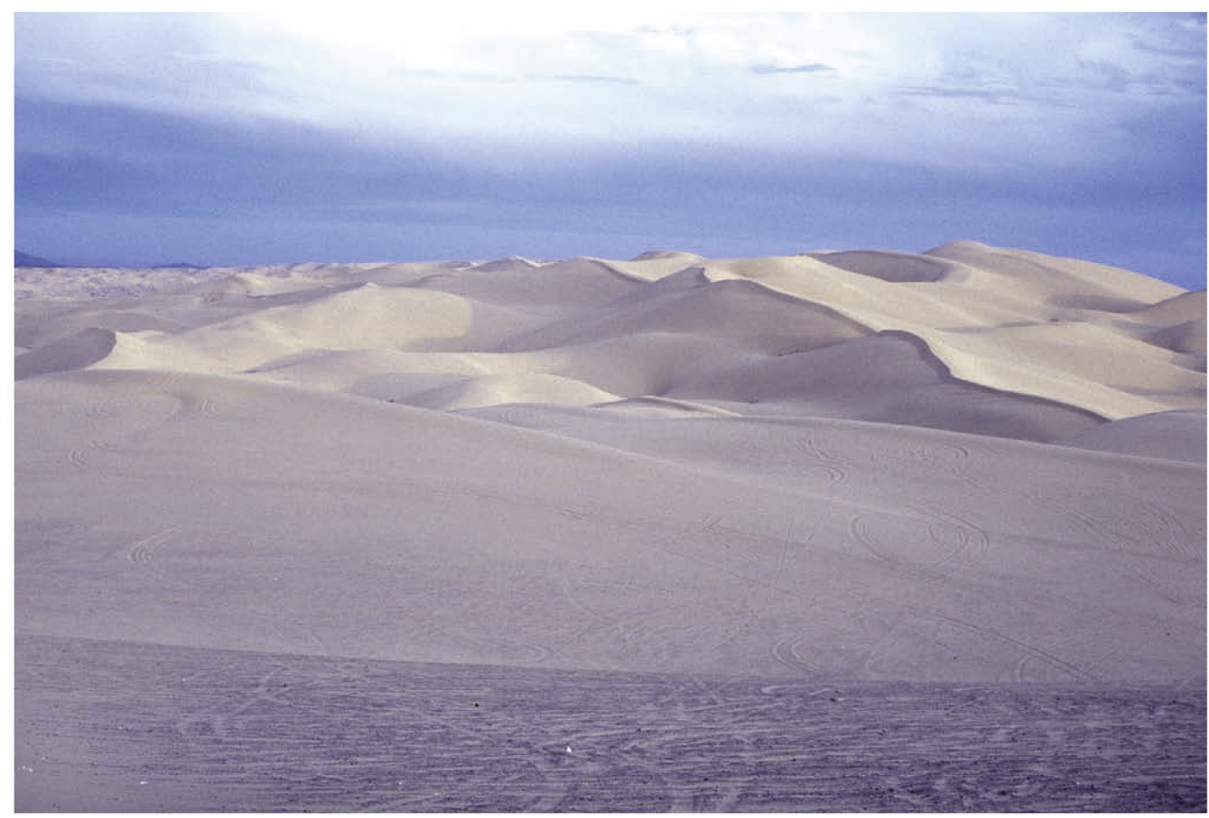

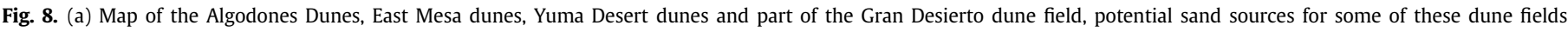

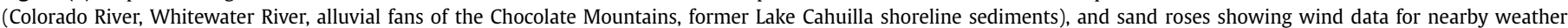

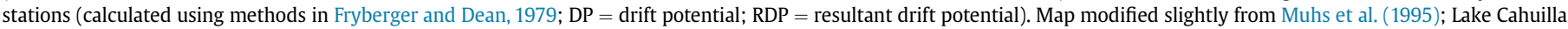
shoreline from Waters (1983); (b) Ground photograph of fully active sand in the southern Algodones Dunes. Photograph by D.R. Muhs.

(Fig. 13) have been studied for more than 70 years. The most recent episodes of dune formation occurred in the late Holocene (Holliday, 1990, 2001). Here, the origin of two of the Southern High Plains dune fields is reexamined using $\mathrm{K} / \mathrm{Rb}$ and $\mathrm{K} / \mathrm{Ba}$ values. Both the Muleshoe dunes and the Lea-Yoakum dunes are east-west-trending linear aeolian sand bodies (Fig. 13). Dunes within both aeolian sand bodies are largely parabolic forms that indicate Holocene dunebuilding winds from the west, similar to the resultant drift directions at present. The geomorphology and wind regime imply a source or sources to the west, which could be either the Pecos River or some parts of the Blackwater Draw Formation. The Blackwater Draw Formation is a complex of Quaternary aeolian sheet sands with intercalated paleosols that may span as much as $1.4 \mathrm{Ma}$ (Holliday, 1989, 1990; Gustavson and Holliday, 1999). It is extensive over the Southern High Plains, east of the Pecos River (Fig. 13).

Results of geochemical analyses show that these two dune 
(a)

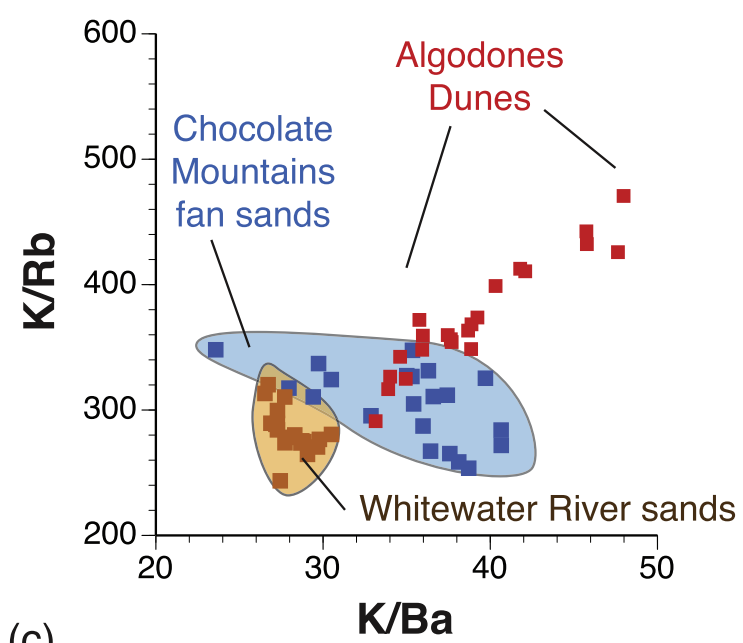

(c)

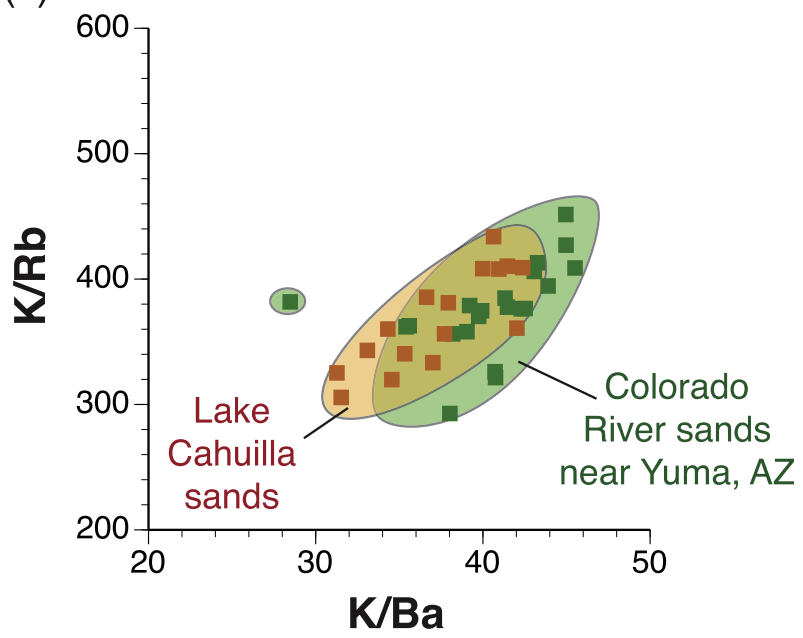

(b)
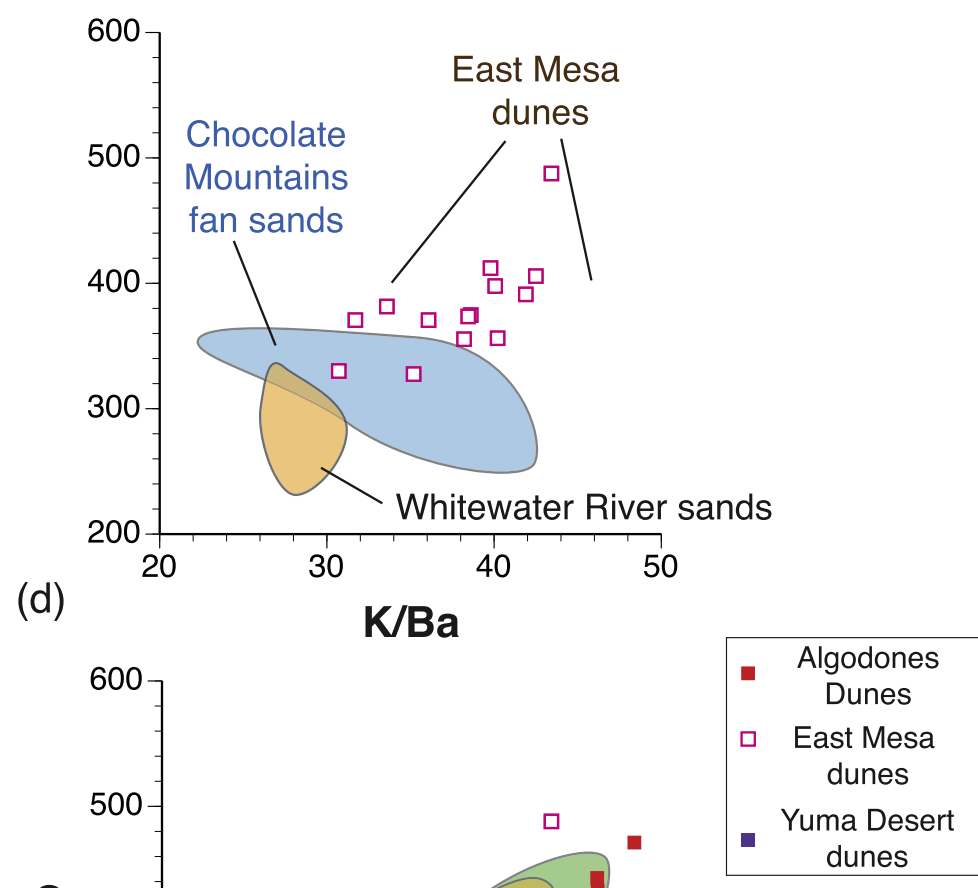

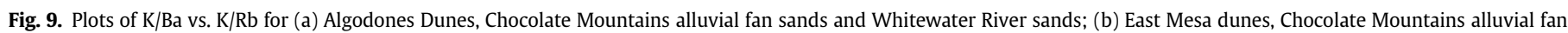

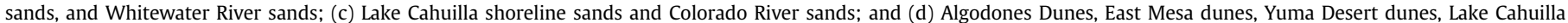
shoreline sands, and Colorado River sands.

sources have distinctive fields defined by $\mathrm{K} / \mathrm{Rb}$ and $\mathrm{K} / \mathrm{Ba}$ values, with only a slight amount of overlap (Fig. 14a and b). Aeolian sand in the Muleshoe dune field has $\mathrm{K} / \mathrm{Rb}$ and $\mathrm{K} / \mathrm{Ba}$ values that fall mostly within the range defined by the Blackwater Draw Formation or slightly beyond it (Fig. 14a). Only a single sample falls within the range of $\mathrm{K} / \mathrm{Rb}$ and $\mathrm{K} / \mathrm{Ba}$ values defined by Pecos River alluvium. The Lea-Yoakum dune field has several localities where $\mathrm{K} / \mathrm{Rb}$ and $\mathrm{K} / \mathrm{Ba}$ values fall within or near the range of Pecos River alluvium, but most fall within the field defined by the Blackwater Draw Formation (Fig. 14b).

\subsection{Great Bend dunes, Kansas}

Dunes along the Arkansas River in Colorado and Kansas have been studied for more than a century, going back at least as far as the work of Gilbert (1896). Aeolian sands occur almost continuously along the south side of the Arkansas River, from near La Junta, Colorado to Wichita, Kansas (Fig. 15a). Gilbert (1896, p. 580) speculated that the Arkansas River valley was the source of the dunes, at least in Colorado, transported by northwesterly winds. Resultant drift directions calculated for Pueblo and La Junta, Colorado, as well as Garden City, Kansas indicate dominant dune-forming winds from the northwest, which supports Gilbert's (1896) hypothesis.
Orientations of Holocene dunes along the Arkansas River in eastern Colorado and westernmost Kansas are largely consistent with northwesterly dune-building winds as well. From Dodge City east to Wichita, however, resultant drift directions indicate dominant dune-forming winds from the southwest and Holocene dune orientations also indicate southerly or southwesterly winds (Fig. 15a; see also Arbogast, 1996, 1998; Arbogast and Johnson, 1998; Arbogast and Muhs, 2000). Nevertheless, the majority of aeolian sand bodies from Dodge City east to Wichita are situated on the southern side of the Arkansas River, as is the case in western Kansas and eastern Colorado. Few sources of sand exist to the south of the Great Bend dunes, despite the evidence for modern southerly winds as a control on the movement of aeolian sand in this dune field. The contradictory observations of dune building from southerly winds and lack of a sand source has generated debate about the origin of aeolian sand in central and western Kansas for more than 60 years.

In the present study, the possible source sediments of the Great Bend dunes were investigated using $\mathrm{K} / \mathrm{Rb}$ and $\mathrm{K} / \mathrm{Ba}$ values in late Holocene aeolian sand, modern Arkansas River alluvium found to the north of the Great Bend dunes, and older Pleistocene alluvium found to the south of the dunes (Fig. 15b). Results indicate that although compositions are very similar, modern Arkansas River 


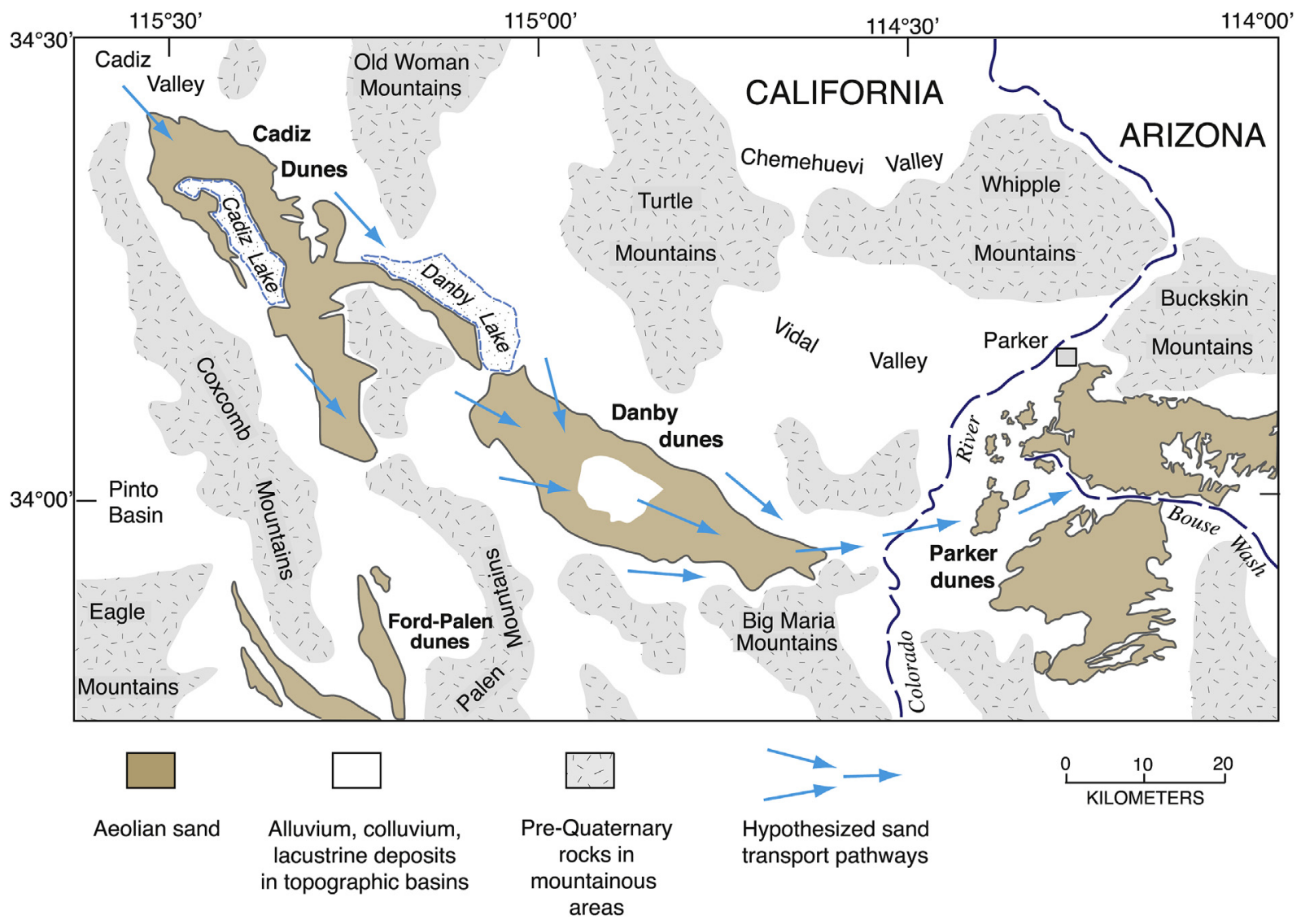

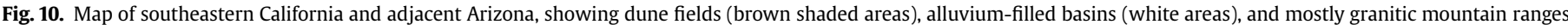

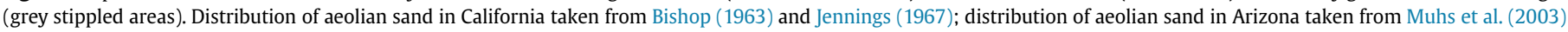
and Fig. 11. (For interpretation of the references to colour in this figure legend, the reader is referred to the web version of this article.)

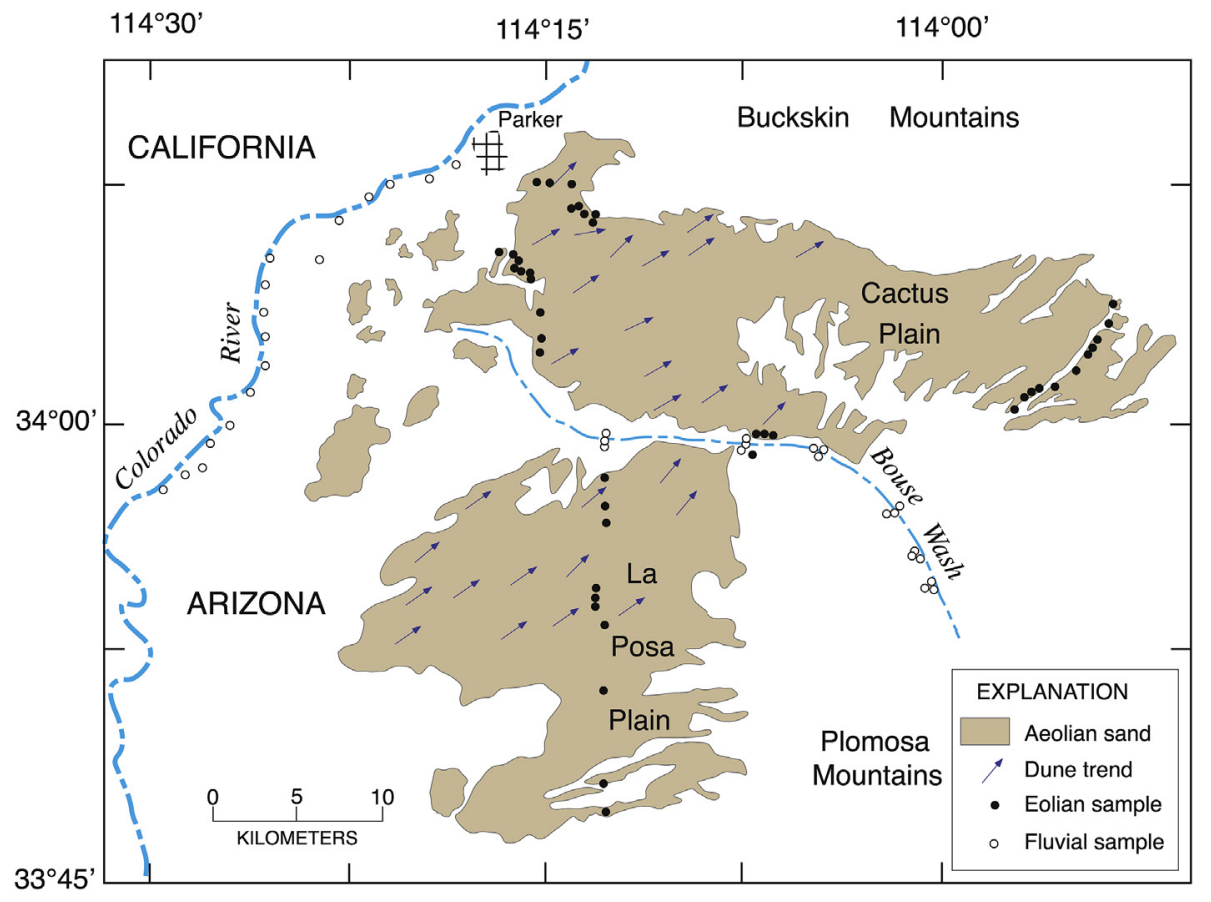

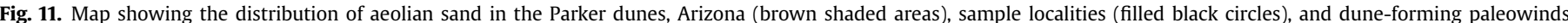

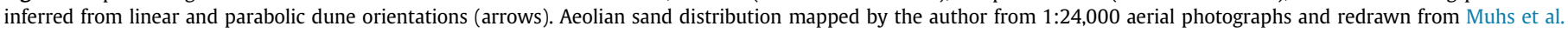
(2003). (For interpretation of the references to colour in this figure legend, the reader is referred to the web version of this article.) 
(a)

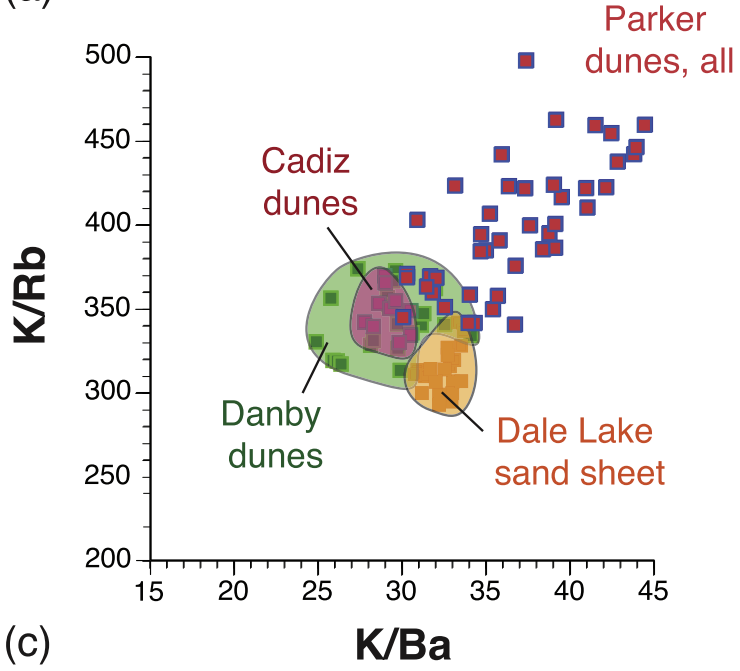

(c)

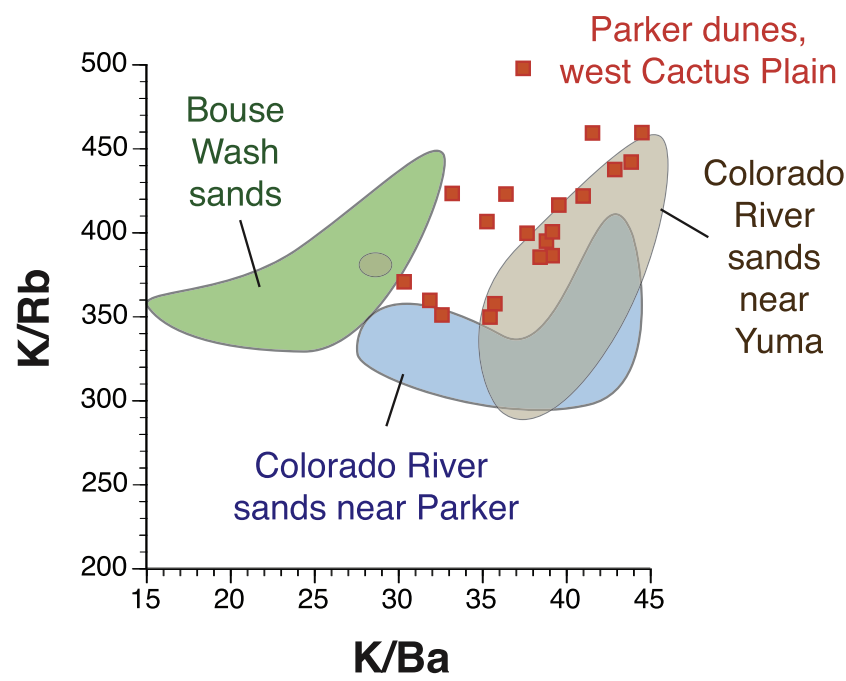

(b)
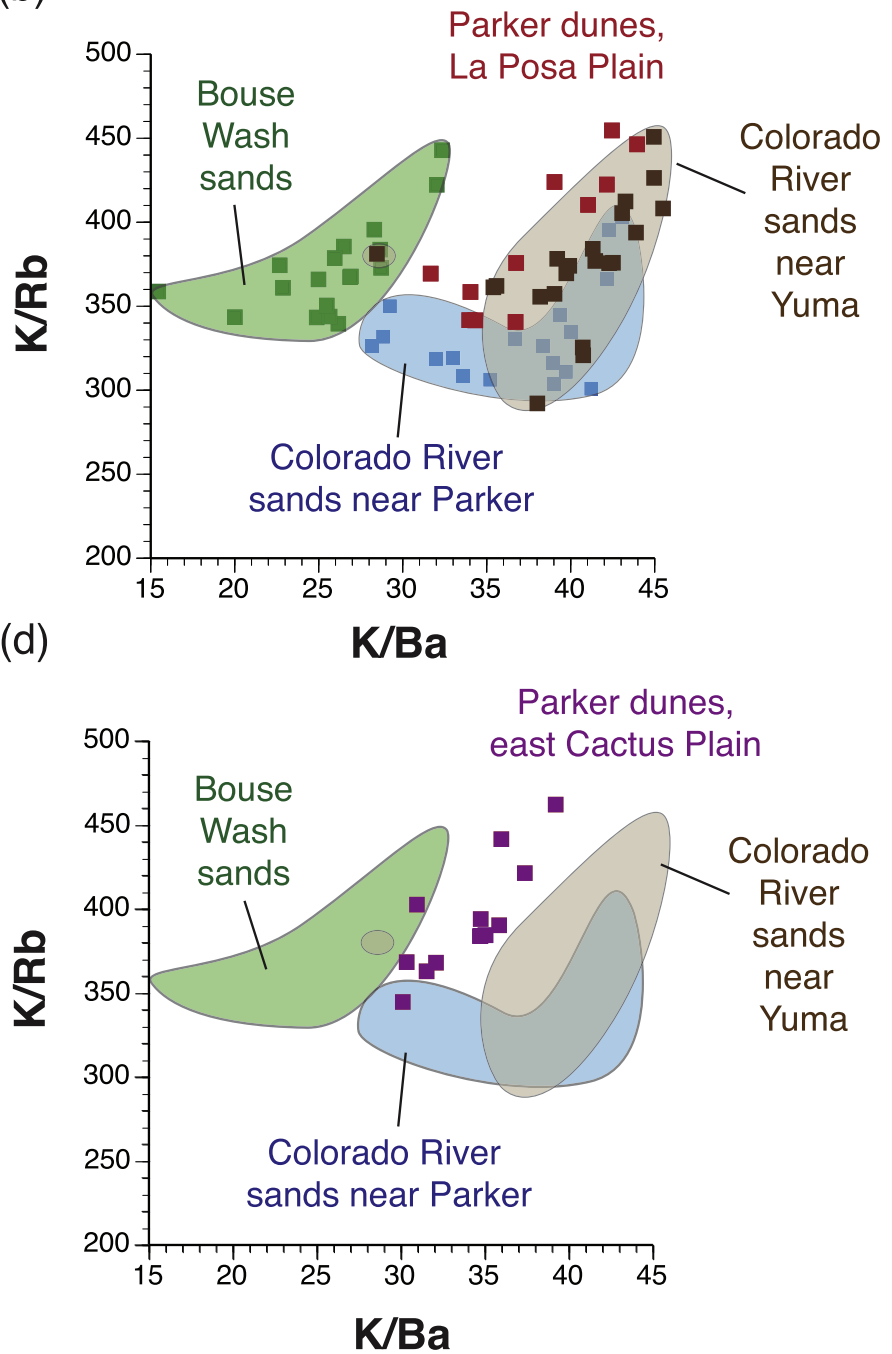

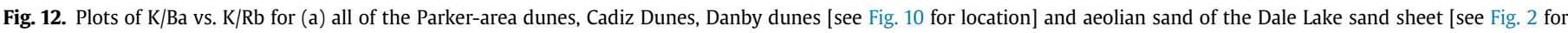

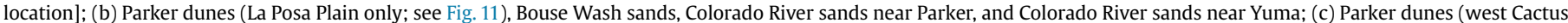

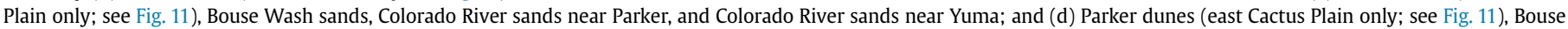
Wash sands, Colorado River sands near Parker, and Colorado River sands near Yuma.

alluvium and Pleistocene alluvium (south of the Great Bend dunes) have very slight differences (Fig. 14c and d). Specifically, Pleistocene alluvium has a somewhat greater range of $\mathrm{K} / \mathrm{Ba}$ compared to modern Arkansas River alluvium. Furthermore, although Great Bend dunes differ little from Pleistocene alluvium in their $\mathrm{K} / \mathrm{Rb}$ and $\mathrm{K} / \mathrm{Ba}$ compositions, the dunes fall squarely within the range of modern Arkansas River alluvium. It should be noted, however, that the upper range of $\mathrm{K} / \mathrm{Rb}$ in modern Arkansas River alluvium is controlled by a single point.

\subsection{Origin of northeastern Colorado dune fields}

Aeolian sand, both of Pleistocene and Holocene age, is widespread over northeastern Colorado (Fig. 16) and has been mapped several times (Scott, 1968, 1978; Sharps, 1976, 1980; Muhs, 1985; Madole, 1995; Muhs et al., 1996; Madole et al., 2005). Aeolian sand of Pleistocene age in northeastern Colorado is often expressed geomorphically as sheet sands, whereas Holocene-aged aeolian sand is typically expressed as parabolic dunes, in both simple and compound forms. Muhs et al. (1996) recognized three dune fields dominated by late Holocene sand, including the Fort Morgan dunes (those immediately to the south of the South Platte River), the Wray dune field, farther to the southeast and extending into Nebraska, and the Greeley dune field, found to the north of the South Platte River (Fig. 16). In all three of these dune fields, late Holocene parabolic dunes usually have arms that point to the northwest, indicating paleowinds from that direction (Figs. 16-18). Furthermore, in the Wray dune field, particle size data for Holocene dunes indicate a general northwest-to-southeast decrease in mean particle size, consistent with the dune geomorphology indicating northwesterly paleowinds (Fig. 18). Potential source sediments for these dune fields include alluvium from the South Platte River, and bedrock from the Cretaceous Fox Hills Sandstone, the Cretaceous Laramie Formation, and the Tertiary Ogallala Formation (Figs. 17 and 18). The Tertiary White River Group is also extensive in northeastern Colorado (Fig. 17), but is dominated by silt-sized particles.

The Fort Morgan dune field contains aeolian sand bodies that collectively parallel the South Platte River, to the south of this drainage (Figs. 16 and 17). With modern winds from the northwest (Fig. 16), this geographic association, along with parabolic dune orientations indicating paleowinds from the northwest, would 

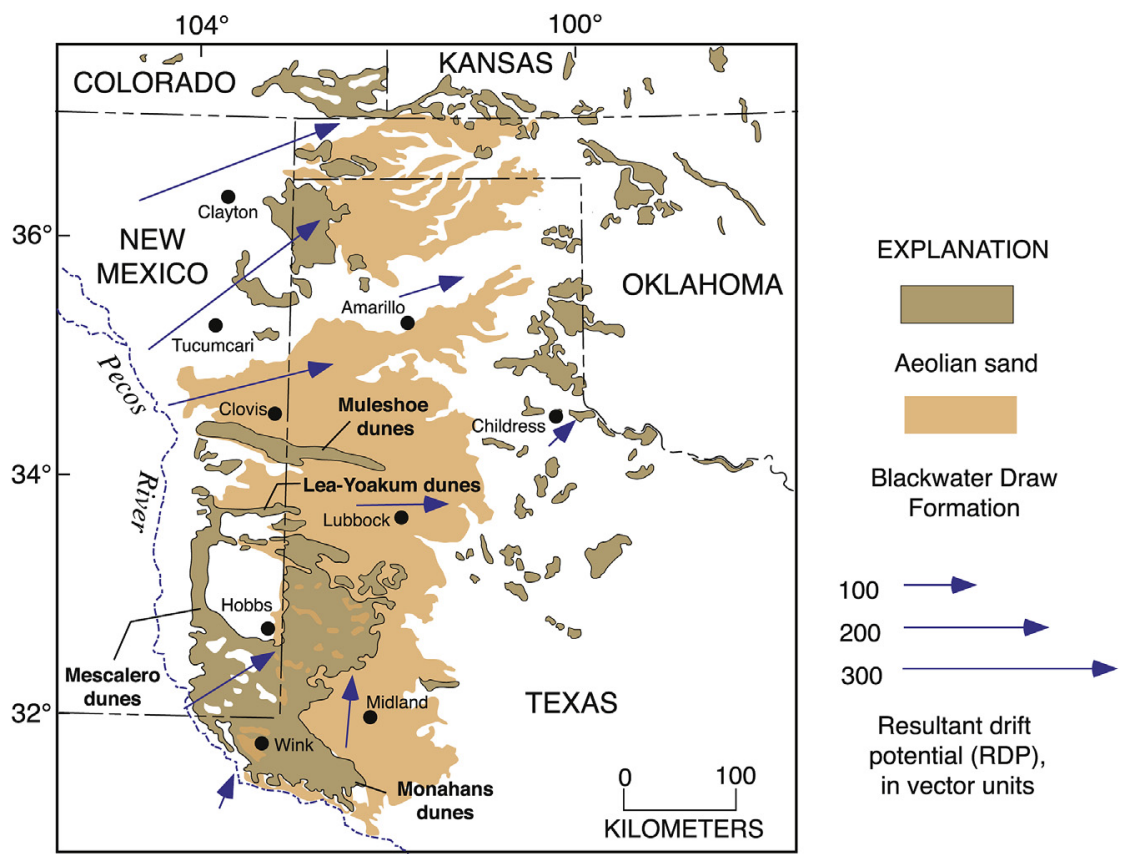

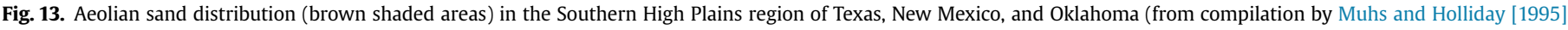

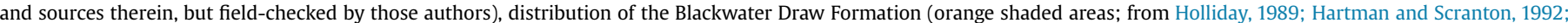

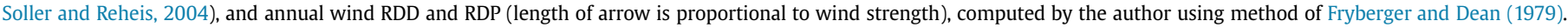
(For interpretation of the references to colour in this figure legend, the reader is referred to the web version of this article.)

suggest that alluvium of the South Platte River is a likely candidate source sediment. In addition, however, bodies of the Cretaceous Laramie Formation (sandstone) as well as the Ogallala Formation, are also situated to the northwest of the Fort Morgan dune field, although most of these rocks are found north of the South Platte River, which could be a barrier to southward sand transport (Fig. 17). Compositional fields defined by $\mathrm{K} / \mathrm{Rb}$ and $\mathrm{K} / \mathrm{Ba}$ values for South Platte River sands and Laramie Formation sands are distinctive (Fig. 19a). Although the Laramie Formation and the Ogallala Formation also have distinctive compositions, sands from the latter formation and those from the South Platte River overlap (Fig. 19b). Indeed, South Platte River sands have K/Rb and K/Ba compositions that fall completely within the larger geochemical field defined by the Ogallala Formation (Fig. 19c). This result is not surprising, as studies of Tertiary paleodrainage indicate that an ancient South Platte River likely drained much of the same region in Colorado as the modern South Platte River (Swinehart et al., 1985).

Fort Morgan dunes do not fall into the field defined by the Laramie Formation, which eliminates that formation as a source (Fig. 19c). Many Fort Morgan dune samples fall into the range for the South Platte River, a few more fall outside this range, but within the field of the Ogallala Formation, and three more fall outside of both fields (Fig. 19c). It is interesting to note that the half-dozen samples with the highest $\mathrm{K} / \mathrm{Ba}$ values were all collected in the westernmost part of the dune field, suggesting there may be another, as yet unidentified source.

For the Wray dune field, both the orientations of late Holocene parabolic dunes and decreasing mean particle size indicate that paleowinds that deposited the sand came from the northwest (Fig. 18). The two main candidate source sediments that lie to the northwest of the Wray dune field are fluvial sands of the South Platte River (Fig. 16) and sands of the Tertiary Ogallala Formation (Fig. 18). Nevertheless, although some late Holocene dune sands in the Wray dune field fall within the range of South Platte River sediments, a significant number of samples do not, indicating possible derivation from the Ogallala Formation.

In order to investigate possible changes in aeolian sand sources over time in the Wray dune field, a thick ( $\sim 9 \mathrm{~m})$ quarry exposure of dune sand reported by Muhs et al. (1999) was studied (Fig. 20; location shown in Fig. 18). The exposure is remarkable for its display of primary bedding (Fig. 20a and b), but also secondary features such as paleosols (Fig. 20a and b), probable bison hoof prints (Fig. 20c), and cicada burrows (Fig. 20d). A thin layer of aeolian sand at the top of the section is interpreted to be historic. Below this, from depths of $\sim 0.9 \mathrm{~m}$ to $\sim 5.8 \mathrm{~m}$, well-bedded aeolian sand hosts a paleosol with an $\mathrm{A} / \mathrm{AC} / \mathrm{C}$ profile in its upper part and is interpreted to be of late Holocene age. A paleosol with a thick, cumulic A horizon in its upper part and clay lamellae in its lower part is developed in an older aeolian sand and is found below the package of late Holocene aeolian sand. At the time of sampling, this unit extended to a depth of $\sim 9 \mathrm{~m}$. Its age is unknown. Mason et al. (2011) documented late Holocene aeolian sand overlying early Holocene/latest Pleistocene aeolian sand elsewhere in the Wray dune field, so it is possible the unit is as old as late Pleistocene.

A trench through the main part of the Wray quarry section was sampled (Fig. 20a) for geochemical analyses. Results for K/Rb, with a very few exceptions, would permit an interpretation of either a South Platte River source, an Ogallala Formation source or both (Fig. 21). However, K/Ba results indicate that much of the aeolian sand in the section was more likely derived from the Ogallala Formation (Fig. 21).

$\mathrm{K} / \mathrm{Rb}$ and $\mathrm{K} / \mathrm{Ba}$ values were determined for late Holocene aeolian sands in the Greeley dune field and bedrock units upwind from it, including the Fox Hills Sandstone, the Laramie Formation, and the Ogallala Formation (Fig. 17). Results show that the Greeley dunes have a composition that is distinct from other Colorado dune fields, with the Greeley dunes having generally lower K/Ba than either the Fort Morgan or Wray dunes (Fig. 22a). The Fox Hills Sandstone has very high $\mathrm{K} / \mathrm{Rb}$ and generally higher $\mathrm{K} / \mathrm{Ba}$ compared to the Greeley dunes (Fig. 22b). There is fair agreement in the compositional range 


\section{(a)}
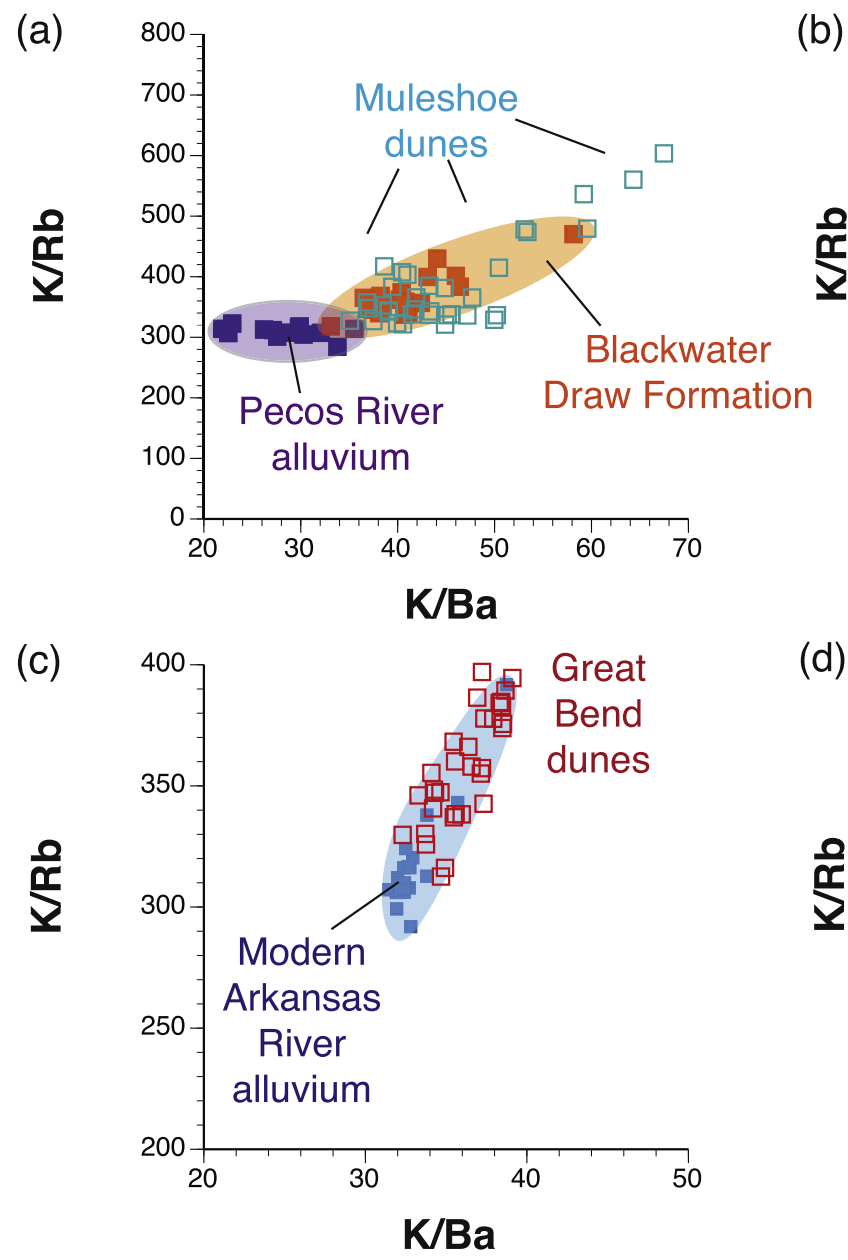

(b)

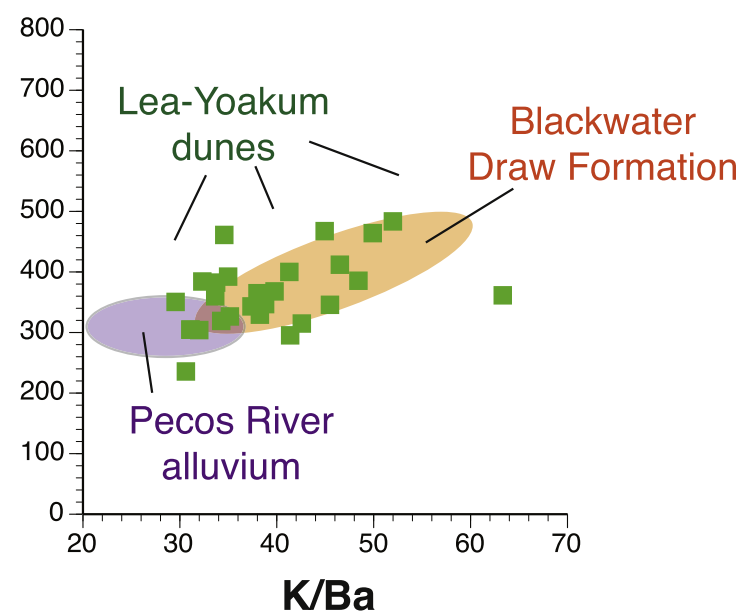

(d)

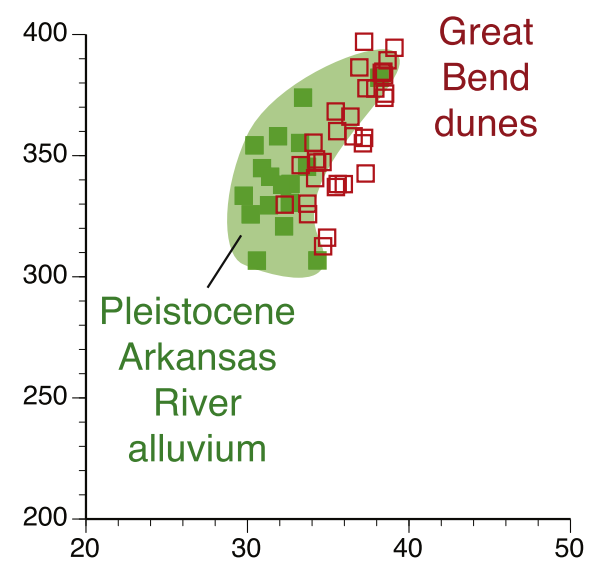

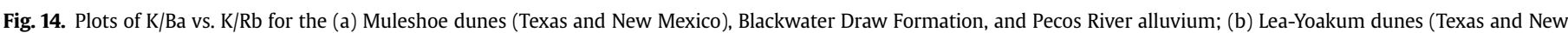

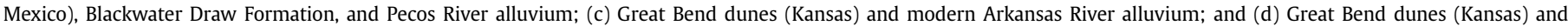
Pleistocene alluvium, possibly derived from the Arkansas River.

of the Greeley dunes with that of the Ogallala Formation (Fig. 22c). There is also fairly good agreement with the $\mathrm{K} / \mathrm{Rb}$ and $\mathrm{K} / \mathrm{Ba}$ compositional field of Laramie Formation sands (Fig. 22c and d), indicating that this formation, or alluvium derived from it, could be a major source of sand. South Platte River sands, however, show almost no overlap with the Greeley dunes (Fig. 22d).

\subsection{Southwestern Nebraska dune fields}

Although the Nebraska Sand Hills dune field is the largest (stabilized) erg in North America (Fig. 3), there are smaller, "satellite" dune fields around this larger sand sea. Two of these dune fields in southwestern Nebraska have been referred to informally as the Lincoln County dune field (= the "Dickens" dune field of Winspear and Pye [1996]) and the Imperial dune field complex (Muhs et al., 2000), both situated to the south of the Nebraska Sand Hills (Fig. 23). Both of these dune fields also lie to the south of the South Platte River and North Platte River. Modern, sandtransporting winds come from the northwest (Fig. 24). Studies by both Winspear and Pye (1996) and Muhs et al. (2000) indicate that aeolian sands in the Lincoln County dune field have quartz and $\mathrm{K}-$ feldspar abundances that are intermediate between sand of the Nebraska Sand Hills and sands of the South Platte River. This suggests the possibility that both of these latter sediment bodies could have been sources for the Lincoln County dune field.

Geochemical analyses show that the Nebraska Sand Hills, sands of the South Platte River and sands of the North Platte River have distinctive fields defined by $\mathrm{K} / \mathrm{Rb}$ and $\mathrm{K} / \mathrm{Ba}$ (Fig. 25a). Lincoln County dunes have $\mathrm{K} / \mathrm{Rb}$ and $\mathrm{K} / \mathrm{Ba}$ compositions that fall between the fields defined by these ratios for the Nebraska Sand Hills and the South Platte River, but also fall squarely within the range of North Platte River sands (Fig. 25b). Furthermore, this K/Rb and K/Ba composition is consistent over two periods of dune accretion (separated by a paleosol), as seen within a 6-m-thick core obtained from a single dune, shown as the "NE-135A auger hole" locality (Figs. 24 and 26).

Aeolian sands of the Imperial dune fields (Fig. 24) have been dated in deep cores to as old as the latest Pleistocene and to as young as the latest Holocene (Mason et al., 2011). Sources similar to those of the Lincoln County dune field can be hypothesized. In addition, however, Ogallala Formation bedrock is exposed at the surface upwind of the Imperial dune fields (Fig. 23). Furthermore, Bettis et al. (2003; their Fig. 12) note that Ogallala Formation bedrock is found at shallow depths below thin loess upwind of the Imperial dune fields. In some places, Ogallala Formation bedrock is also found immediately below late Pleistocene aeolian sand in the Imperial dunes (see Fig. 4g of Mason et al., [2011]). All these observations indicate that in addition to candidate sand sources identified for the Lincoln County dunes, sands from the Ogallala Formation could also be considered as possible sources for the Imperial dunes. Results of $\mathrm{K} / \mathrm{Rb}$ and $\mathrm{K} / \mathrm{Ba}$ analyses indicate that late Holocene sands of the Imperial dunes fall between the 
(a)

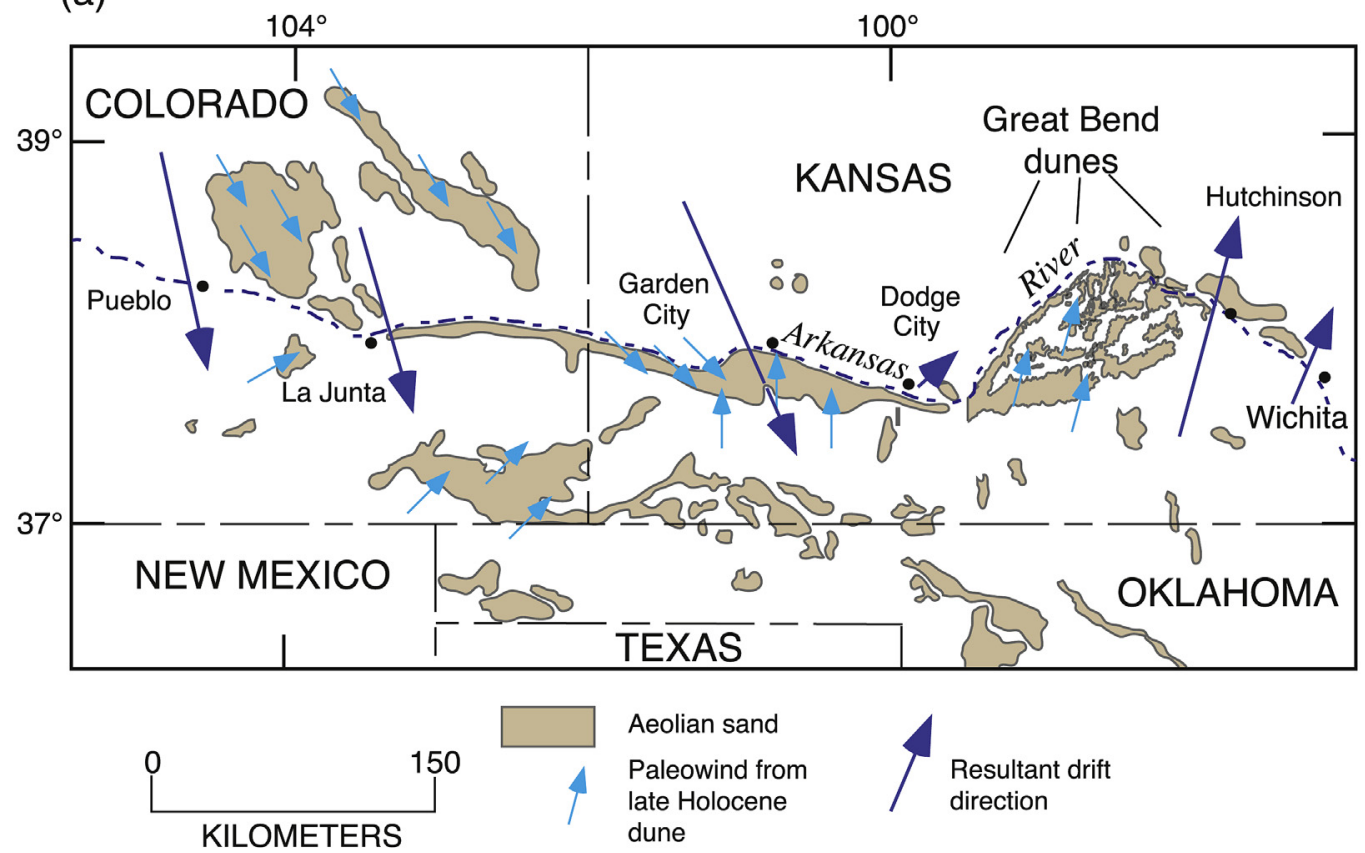

(b)

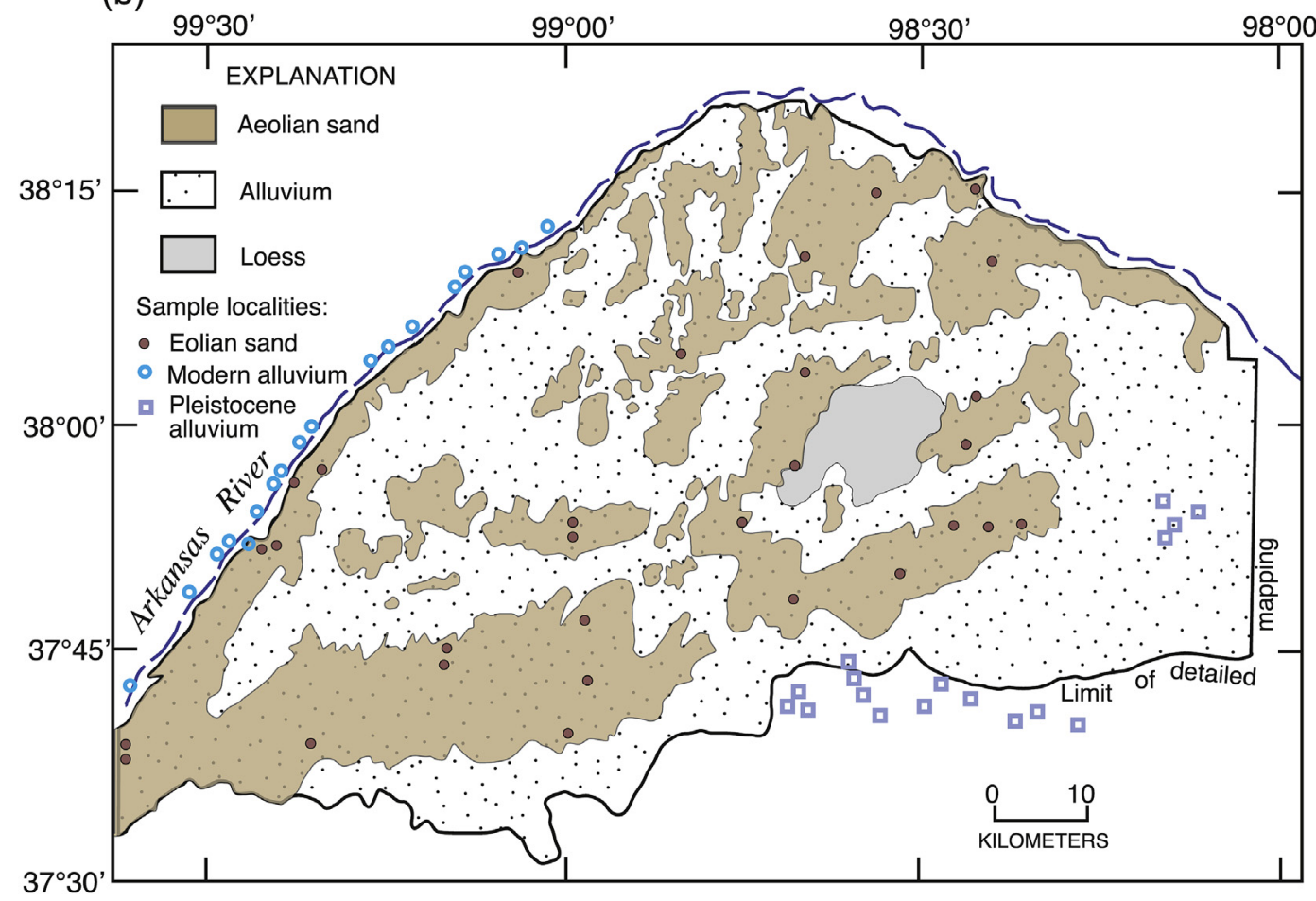

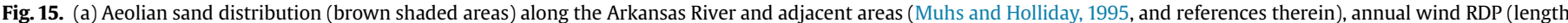

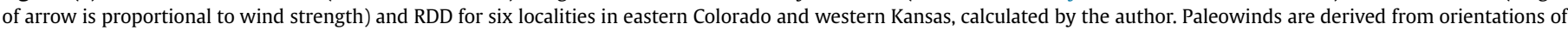

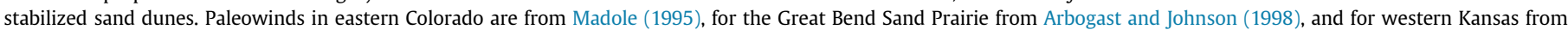

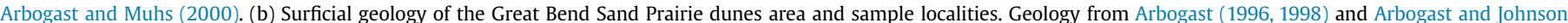

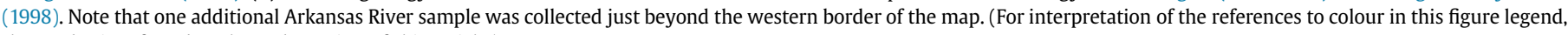
the reader is referred to the web version of this article.)

compositional fields of the Nebraska Sand Hills and the South Platte River, but closer to South Platte River sands (Fig. 25c). Further, many of the Imperial dunes fall within or close to the compositional field of the Ogallala Formation.

Finally, smaller occurrences of aeolian sand are found on the interfluve between the North Platte River and South Platte River (Fig. 24). These patches of aeolian sand are as much as $\sim 3 \mathrm{~m}$ or more thick in places and host weakly developed $\mathrm{A} / \mathrm{AC} / \mathrm{C}$ profiles, similar to the surface soils in late Holocene aeolian sand over much of the Nebraska Sand Hills, the Lincoln County dune field, and the 


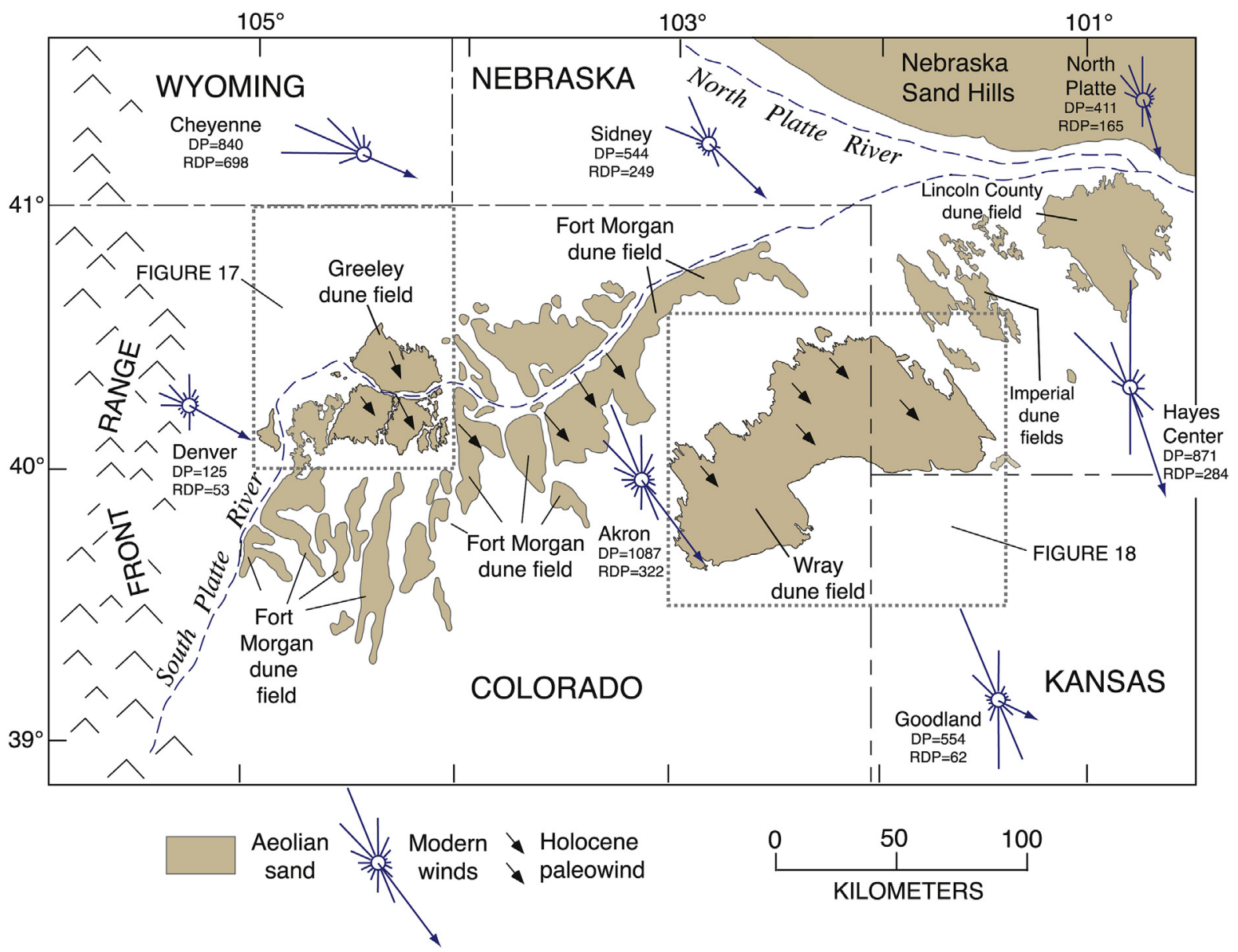

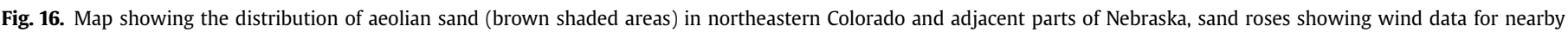

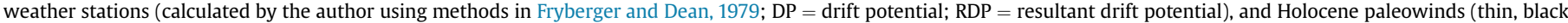

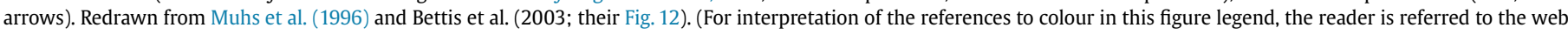
version of this article.)

Imperial dune fields. In these sands, $\mathrm{K} / \mathrm{Rb}$ and $\mathrm{K} / \mathrm{Ba}$ fall between the compositional fields of the Nebraska Sand Hills and North Platte River sands or within the North Platte River sand field (Fig. 25d).

\subsection{The Nebraska Sand Hills}

The Nebraska Sand Hills region extends over more than $50,000 \mathrm{~km}^{2}$ and is the largest dune field in North America (Figs. 3 and 27). Almost all of the region is stabilized by vegetation, but many studies conducted in the past two decades have documented that not only was the dune field active in late Pleistocene time (Mason et al., 2011), but virtually all of it has seen activity in the late Holocene (Swinehart and Diffendal, 1990; Muhs et al., 1997a; Stokes and Swinehart, 1997; Mason et al., 2004; Forman et al., 2005; Miao et al., 2007; Schmeisser McKean et al., 2015) and even historic time (Muhs and Holliday, 1995). These studies have shown that this large dune field is highly sensitive to changes in moisture regime that control the degree of stabilizing vegetation. Nevertheless, the " $50,000 \mathrm{~km}^{2}$ gorilla in the room" that is rarely discussed is the source of the sand itself.

Here, five possible sources of aeolian sand for the Nebraska Sand Hills are considered, although it is emphasized that these need not be the only sources possible. Two of these are unconsolidated fluvial sediments, sands from the North Platte River and South Platte River, both which are situated mostly to the southwest or south of the dune field (Fig. 27). Other possible source sediments for the Nebraska Sand Hills are of preQuaternary age. Pliocene sheet sands, some thought to be of aeolian origin, occur beneath the Nebraska Sand Hills. These sediments, mostly unconsolidated, are at least $20 \mathrm{~m}$ thick in places. The full geographic extent of these Pliocene sands is unknown, but a minimum distribution has been documented by Myers (1993), Swinehart et al. (1994b), and May et al. (1995), and is shown in Fig. 27. In the present study, 18 samples from six localities where Pliocene sands are exposed were analyzed. Two other possible dune sources northwest of the Nebraska Sand Hills are the Tertiary Ogallala Formation and the somewhat older Tertiary Arikaree Formation (Fig. 28).

Sands of the North Platte and South Platte Rivers have K/Rb and $\mathrm{K} / \mathrm{Ba}$ compositions that are mostly distinct from one another, as noted earlier (Fig. 29a). These possible source sediments overlap very little with those of the Nebraska Sand Hills (Fig. 29b). Pliocene sediments, favored by May et al. (1995) and presumably by Winspear and Pye (1996) as a likely source for the Nebraska Sand Hills, show a partial overlap with the aeolian sands (Fig. 29b). Although the composition of the Pliocene sediments is somewhat closer to those of the Nebraska Sand Hills than is the case with the North and South Platte Rivers, it would appear that this is at best a contributing, rather than primary source. The two bedrock units, the Arikaree and Ogallala Formations, show more variability than 


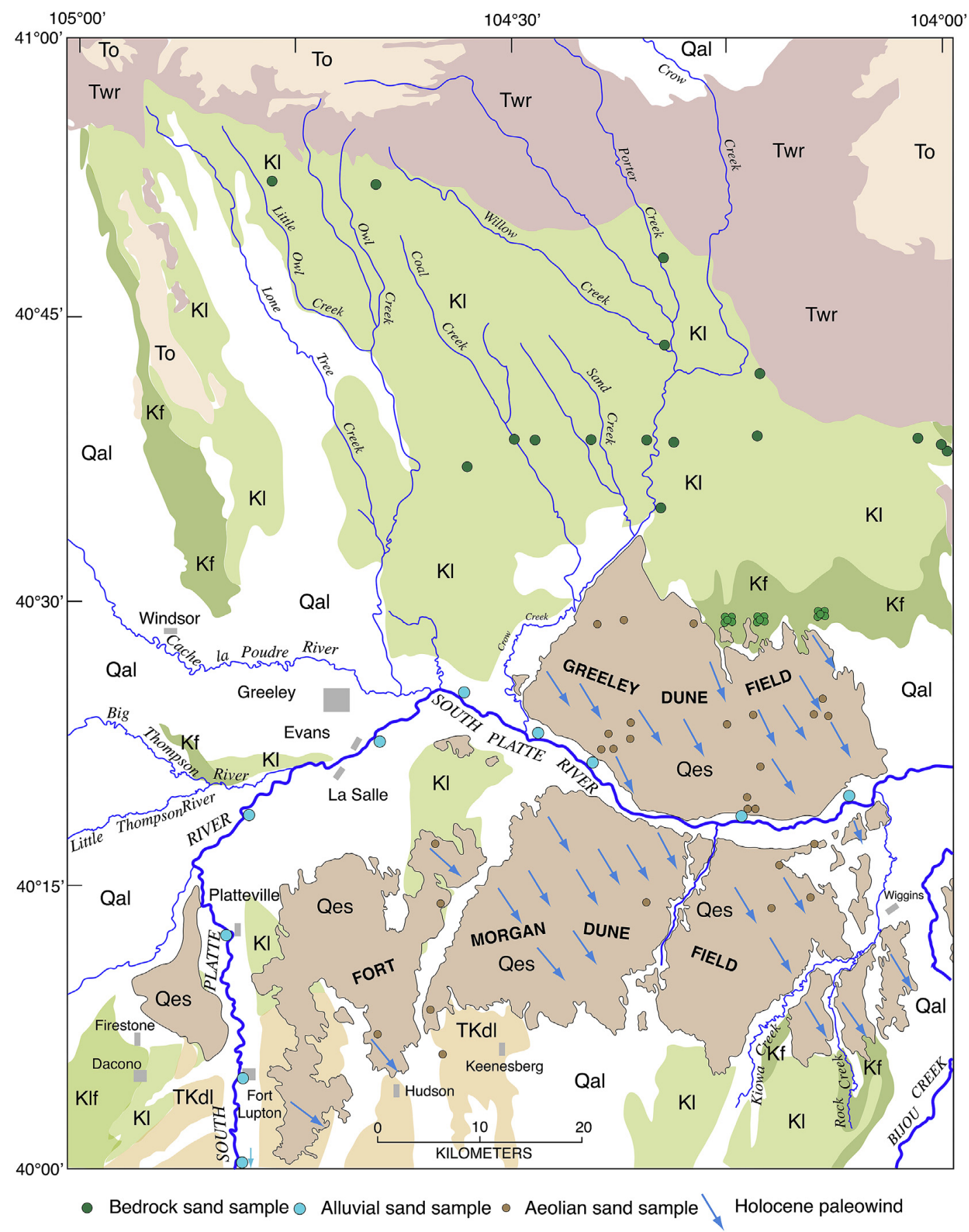

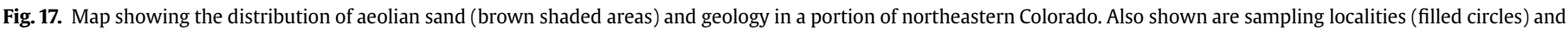

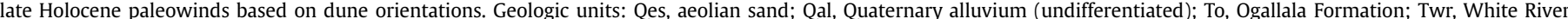

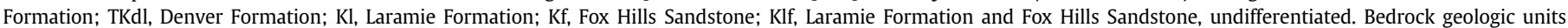

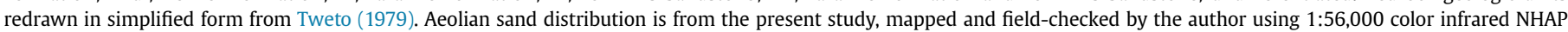

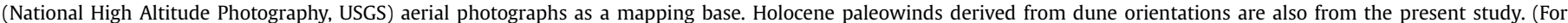
interpretation of the references to colour in this figure legend, the reader is referred to the web version of this article.)

do the other sediments (Fig. 29c). The Tertiary Arikaree Formation, found to the northwest of the Nebraska Sand Hills (Fig. 28), shows more overlap in $\mathrm{K} / \mathrm{Rb}$ and $\mathrm{K} / \mathrm{Ba}$ composition with the Sand Hills dunes than either the rivers or the Pliocene sediments (Fig. 29d). The Tertiary Ogallala Formation underlies much of the Nebraska Sand Hills (Swinehart and Diffendal, 1990) and occurs to the northwest of the dune field as well (Fig. 28). Where this formation crops out in Nebraska, South Dakota and Wyoming, it differs in composition from that in Colorado (compare Figs. 19b and 29c). Outside of Colorado, the Ogallala Formation sands have about the same range of $\mathrm{K} / \mathrm{Ba}$ as those in Colorado, but have a greater (and higher) range of $\mathrm{K} / \mathrm{Rb}$. This result is not surprising because reconstructed Tertiary paleodrainages (Swinehart et al., 1985) indicate that what was likely an ancestral North Platte River had its sources in Wyoming (similar to the modern North Platte River) whereas an ancestral, Tertiary South Platte River had its main sources in 


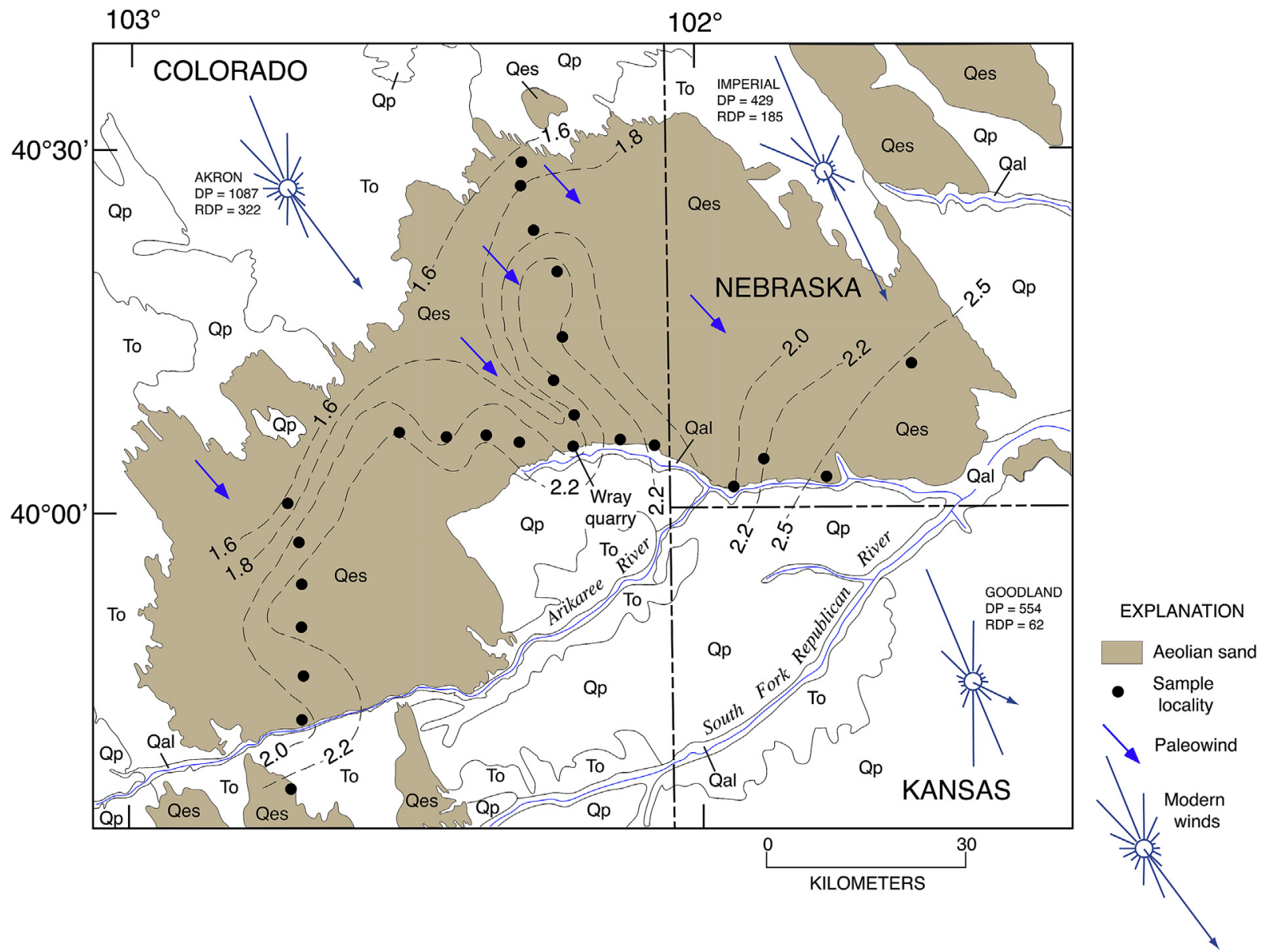

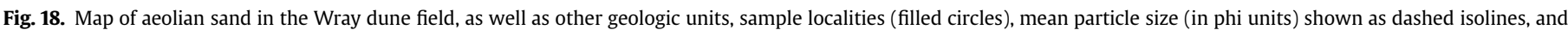

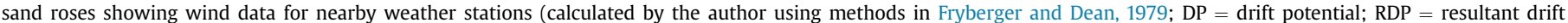

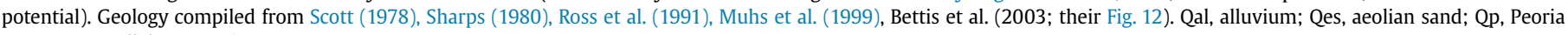
Loess; To, Ogallala Formation.

Colorado (similar to the modern South Platte River). The portion of the compositional field of the Ogallala Formation that has the highest $\mathrm{K} / \mathrm{Rb}$ shows the greatest overlap with the Nebraska Sand Hills of any of the possible source sediments.

It is important, in a large dune field such as the Nebraska Sand Hills, to consider whether multiple sources may have contributed to the aeolian sands and whether the sources may have changed over time. As shown earlier, although source sediments apparently did not change over time in the Lincoln County dune field, they did apparently change over the course of aeolian sand deposition within the Wray dune field of eastern Colorado. Here, $\mathrm{K} / \mathrm{Rb}$ and $\mathrm{K} /$ $\mathrm{Ba}$ are examined in sands from two deep drill holes in dunes of the Nebraska Sand Hills (Gudmundsen Ranch, NE, N42.08 $\sim \mathrm{W} 101.44^{\circ}$; and near Nenzel, NE, $\sim \mathrm{N} 42.996^{\circ}, \sim \mathrm{W} 101.11^{\circ}$ ), studied earlier by Muhs et al. (1997a). Although the Nenzel locality is undated and the upper few meters of the dunes at Gudmundsen date to the late Holocene (Schmeisser McKean et al., 2015), plant materials from beneath the aeolian sand at a depth of $\sim 46 \mathrm{~m}$ at Gudmundsen yielded a radiocarbon age of $\sim 15,000$ cal yr BP (Swinehart and Diffendal, 1990). Samples collected at various depths from the cores at these two localities show that $\mathrm{K} / \mathrm{Rb}$ and $\mathrm{K} / \mathrm{Ba}$ in the sands fall within the overall range of values for these element pairs found throughout the Nebraska Sand Hills (Fig. 30). Thus, it can be inferred from this that either the source of sand has not changed over much of the past $\sim 15,000 \mathrm{yr}$, or perhaps more likely, sand from one or more sources has been well mixed through aeolian transport over this time period or prior to it.

\section{Discussion}

\subsection{Use of $K / R b$ and $K / B a$ as indicators of diversity of dune and dune source compositions}

Results of the analyses given here show that $\mathrm{K} / \mathrm{Rb}$ and $\mathrm{K} / \mathrm{Ba}$, as measures of K-feldspar composition, are effective geochemical indicators of dune sand provenance. A plot of these two ratios shows that aeolian-sand-sized sediments in major river systems of the Great Plains are distinct from one another, reflecting the different rock types that these rivers drain (Fig. 6a). Similar plots for dune fields throughout North America show that aeolian sands in each region are distinct from one another, both in the arid regions of the Basin and Range (Fig. 6b) and the semiarid Great Plains (Fig. 6c and d). This simple exercise shows that $\mathrm{K} / \mathrm{Rb}$ and $\mathrm{K} / \mathrm{Ba}$ are potentially effective discriminators for K-feldspars derived from different source sediments, in turn derived from different rock types. A revisiting of dune fields from many parts of North America, using K/ $\mathrm{Rb}$ and $\mathrm{K} / \mathrm{Ba}$ values of aeolian sands and source sediments shows that some previous interpretations of dune field origins are supported, whereas in other dune fields, the data provide new insights and may require some modification of existing hypotheses. 

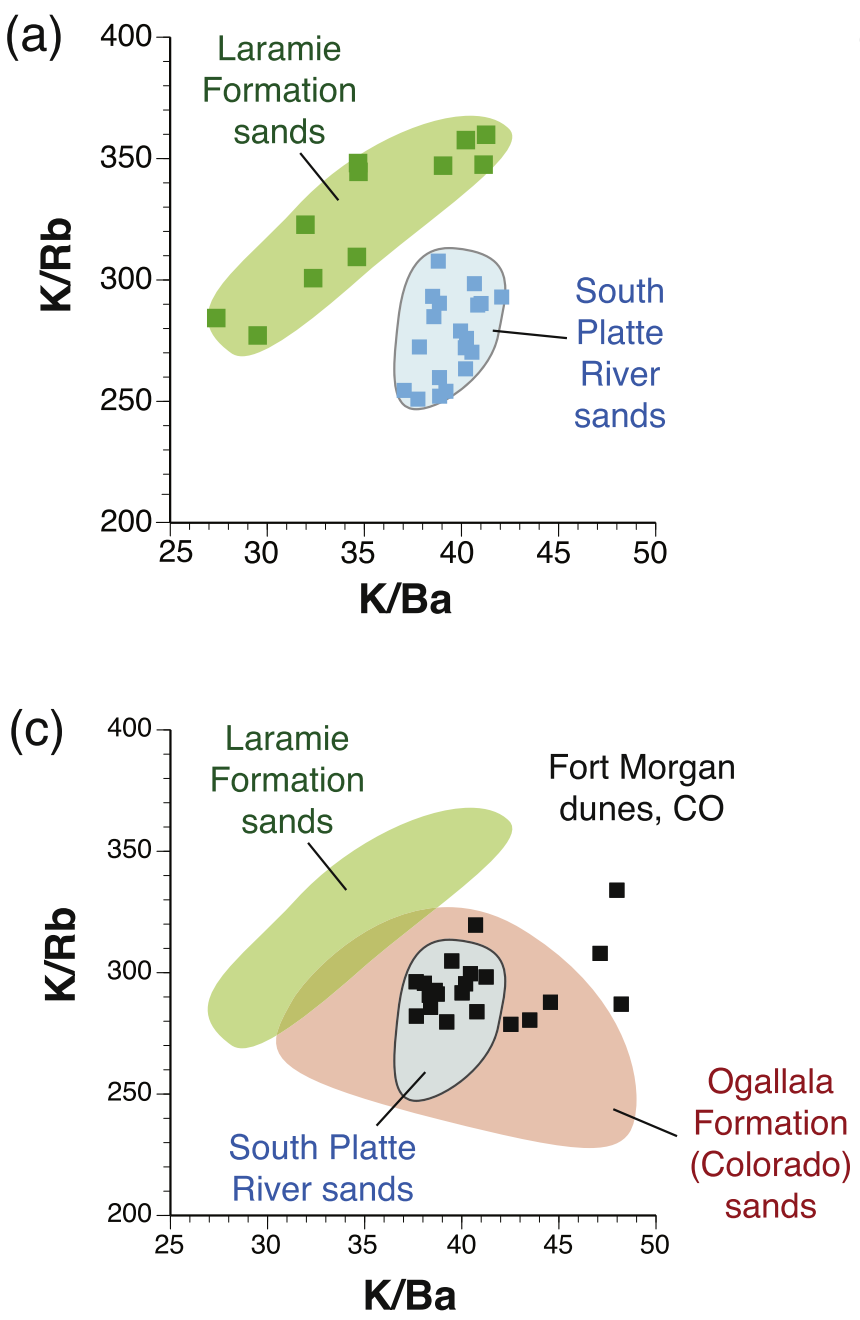
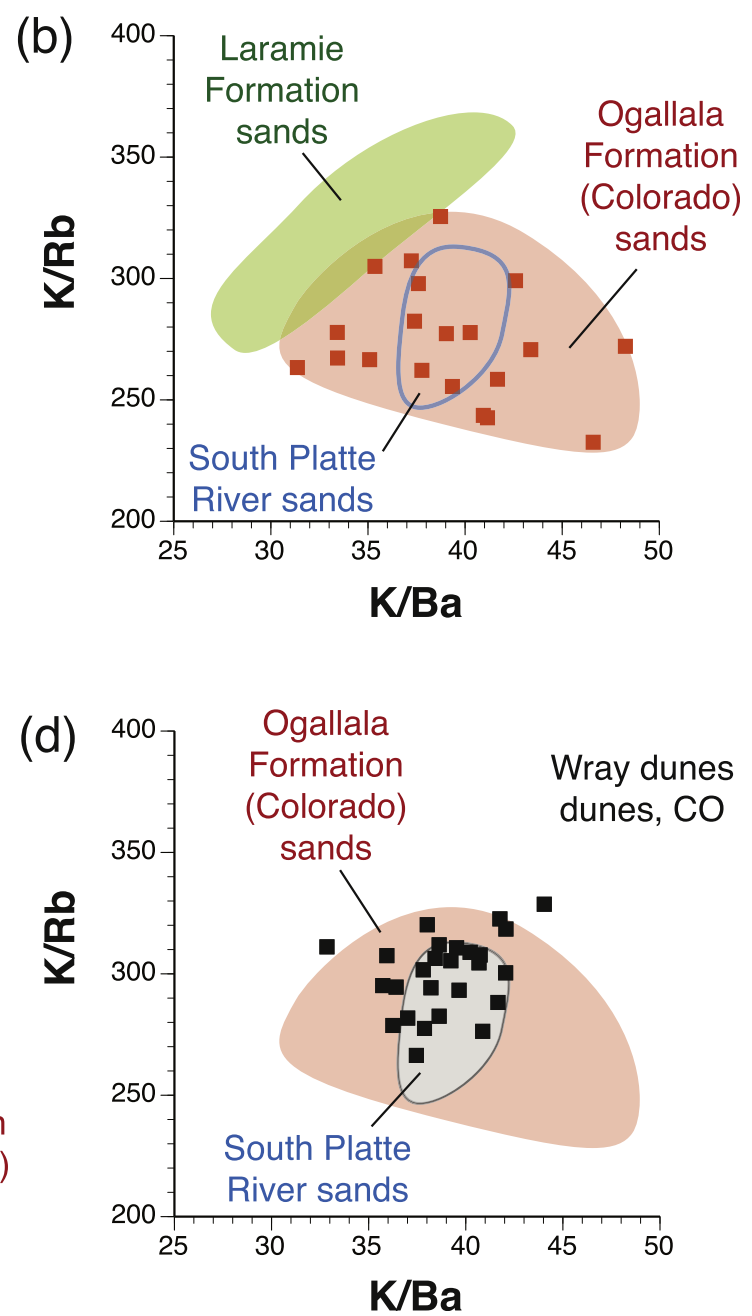

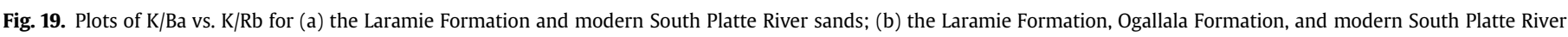

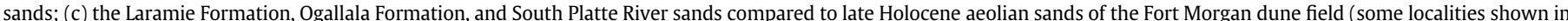

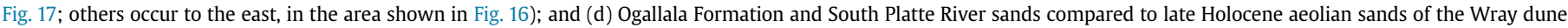
field (localities shown in Fig. 18).

\subsection{Origin of the Algodones Dunes, East Mesa dunes, and Yuma Desert dunes, Sonoran Desert}

In the Sonoran Desert of southeastern California, there has been considerable debate about the origin of the Algodones Dunes (active) and the nearby East Mesa dunes (stabilized). One of the early investigators of dunes in the deserts of southern California was Blake (1857), who thought that Algodones dunes were derived from a gravel plain (presumably alluvial sediments) under northerly winds, but he is not specific as to which deposits he means. In contrast, Brown (1923) proposed a much more specific source for the Algodones Dunes, namely beach sediments from ancient Lake Cahuilla (Fig. 8). As discussed earlier, Lake Cahuilla was a former water body that filled a portion of the region when the Colorado River was naturally diverted into the Salton Basin in the Holocene instead of flowing into the Gulf of California, as it does at present (Fig. 7). The modern Salton Sea formed as a result of a similar diversion (due to both natural causes and flow regulation) in historical time. Norris and Norris (1961) proposed that most sediment entering the Colorado Desert region is derived from the San Bernardino Mountains via Whitewater River and other drainages from the north, and from streams draining the Peninsular Ranges to the east (Fig. 8). These investigators felt that little sediment was contributed to the basin by small streams draining the Chocolate Mountains to the east, or from the Colorado River. They ultimately concluded that the primary source of the Algodones dune field was Lake Cahuilla sediments, but considered that the latter were derived from fluvial sediments of the Whitewater River, with alluvial fan sediments derived from the Chocolate Mountains being a secondary source, a conclusion also accepted by McCoy et al. (1967). Later workers, however, considered that Colorado River sediments were more important as sources for both Lake Cahuilla sands and aeolian sediments in the region (Merriam, 1969; Van de Kamp, 1973; Loeltz et al., 1975; Smith, 1982; Sweet et al., 1988, 1991; Dohrenwend and Smith, 1991). Some of these investigators presented mineralogical data in support of this hypothesis and others did not. Muhs et al. (1995) studied the mineralogy and geochemistry of Whitewater River sands, Chocolate Mountain fan sands, Lake Cahuilla sands, and Colorado River sands and compared these data to the compositions of Algodones Dunes and East Mesa dune sands. They concluded that both Algodones and East Mesa dune sands originated from Lake Cahuilla sands, which in turn were derived from Colorado River sands. Independently, Winspear and Pye (1995) also conducted mineralogical and geochemical studies of the Algodones Dunes and Colorado River sediments and reached the same conclusions as Muhs et al. (1995). 
(a)

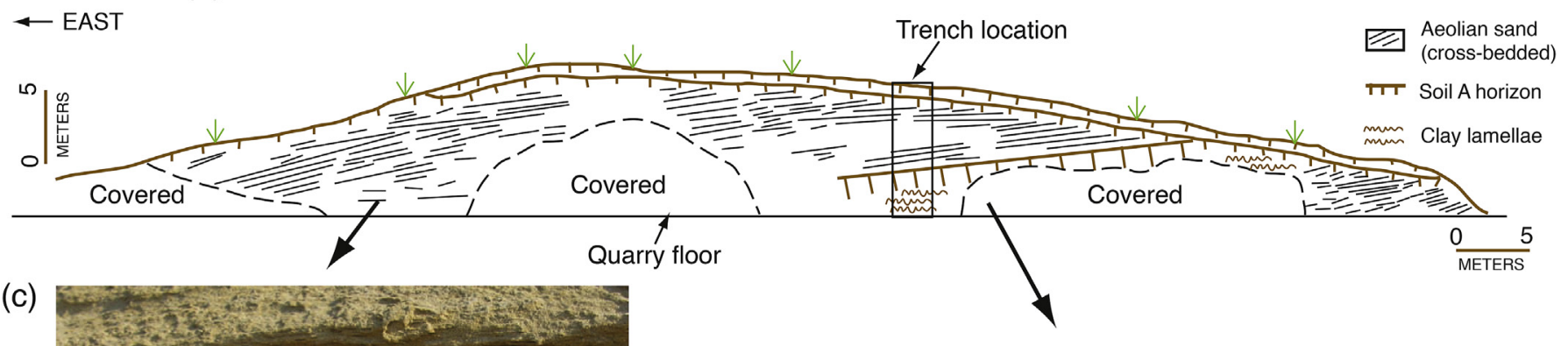

(c)

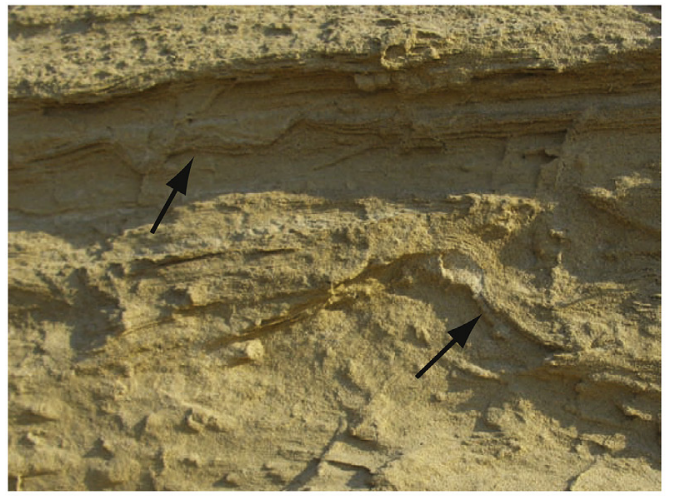

(d)
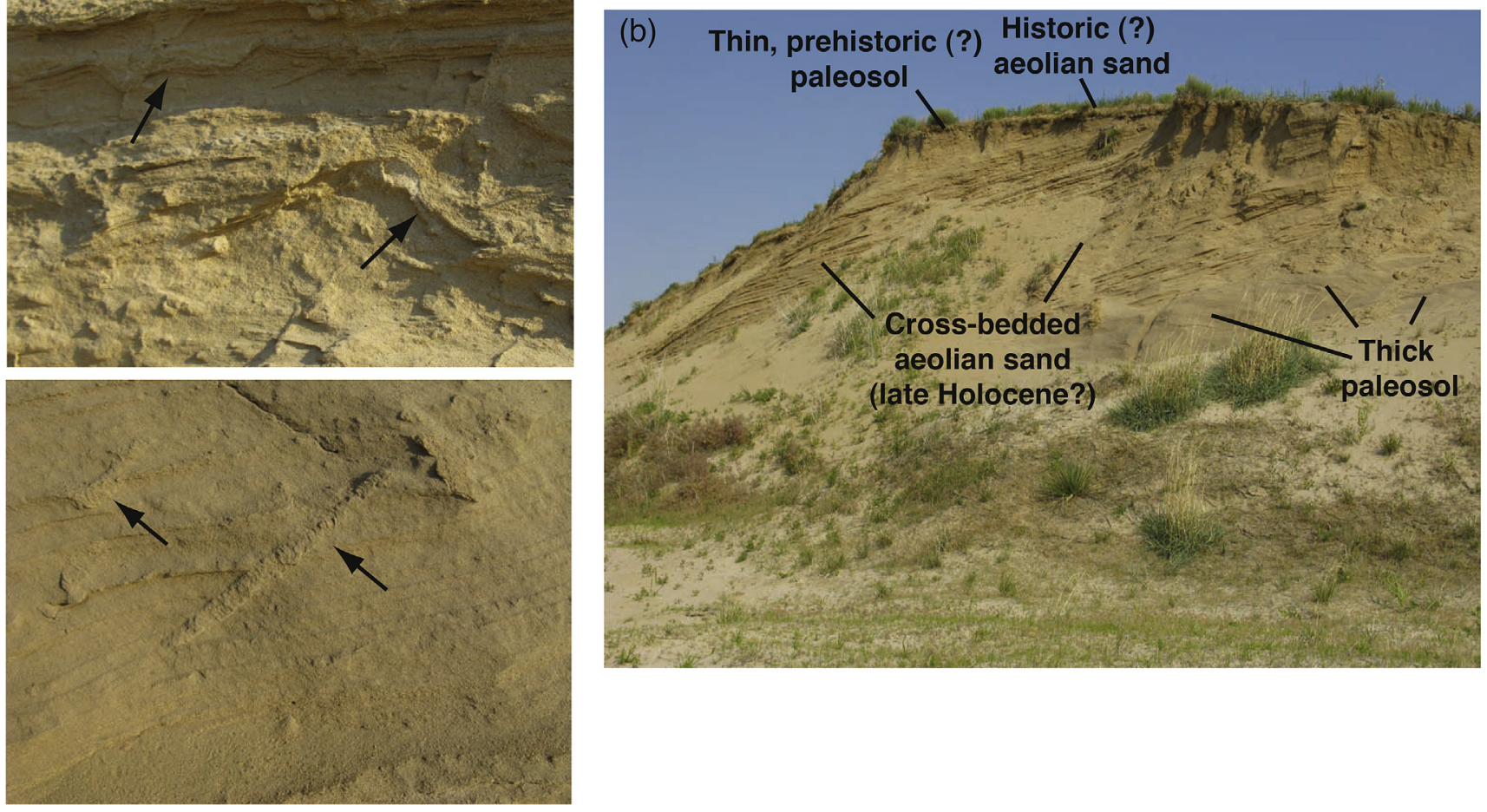

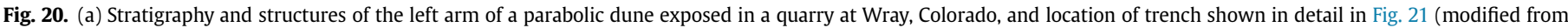

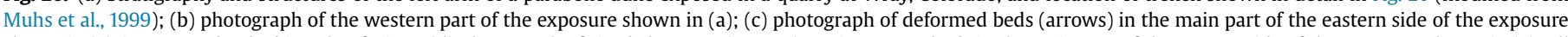

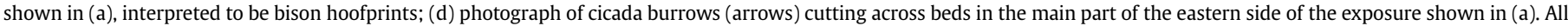
photographs by D.R. Muhs.

The new results presented here show that $\mathrm{K} / \mathrm{Rb}$ and $\mathrm{K} / \mathrm{Ba}$ of the Algodones Dunes and East Mesa dunes are similar, supporting the interpretation of a common origin (Fig. 9). Further, K/Rb and K/Ba in both dune fields have values that do not show close overlap with sands from nearby Chocolate Mountain alluvial fans or Whitewater River sands, derived from the San Bernardino Mountains. Instead, $\mathrm{K} / \mathrm{Rb}$ and $\mathrm{K} / \mathrm{Ba}$ from the Algodones Dunes and East Mesa dunes show good agreement with those from both Lake Cahuilla sands and Colorado River sands, supporting an immediate origin from Lake Cahuilla sediments and an ultimate origin from the Colorado River. Through this interesting geomorphic history, then, a counterintuitive conclusion can be drawn, namely that the Colorado River, which is downwind from the Algodones and East Mesa sands, is the ultimate source of these dune fields. East et al. (2015) reached a similar conclusion in their studies of the origin of dunes in the Thar Desert of India, where the ultimate (but not immediate) source of sand is downwind of the dunes.

Direct derivation of aeolian sand from the Colorado River, however, is apparent in the data presented here for the Yuma Desert dunes, to the southeast of the Algodones Dunes (Figs. 7 and 8). Breed (1999) speculated that the Yuma Desert dunes were derived from alluvium eroded from the Gila Mountains, situated to the northeast of the Yuma Desert. These mountains are composed of Mesozoic gneiss, schist, and granite (Wilson, 1960; Olmsted et al., 1973). In contrast, Muhs et al. (2003) used geochemistry to infer a K-feldspar-poor composition of the Yuma Desert dunes and hypothesized a Colorado River origin. One problem with the interpretation of Muhs et al. (2003) is that if abrasion and ballistic impacts had occurred over a long period within the Quaternary in the Yuma Desert, the dunes there could have a low K-feldspar composition due simply to erosional loss, rather than derivation from a quartz-rich source such as the Colorado River. Thus, if the Yuma Desert sands were ultimately derived from the Gila Mountains as proposed by Breed (1999) and then subjected to repeated K-feldspar loss, the result could still be a K-feldspar-poor dune field. The results presented here show, however, that dunes and sand sheets of the Yuma Desert have K/Rb and K/Ba compositions similar to the Algodones Dunes and East Mesa dunes, indicating a common Colorado River source. An interesting difference between the Yuma Desert dunes and the Algodones/East Mesa dunes is that while both were ultimately derived from the Colorado River, the former were directly derived from the river, whereas the latter were not. 

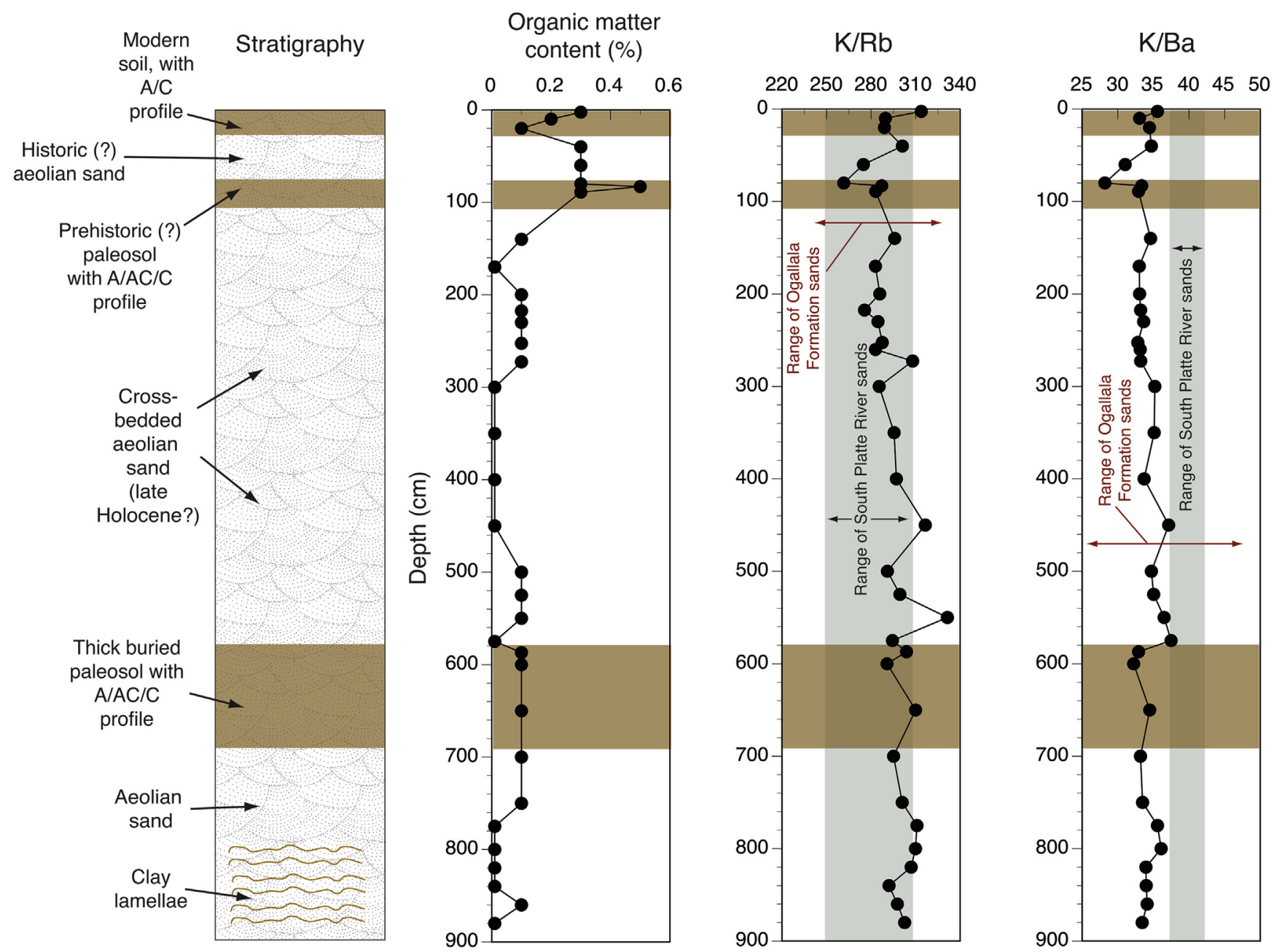

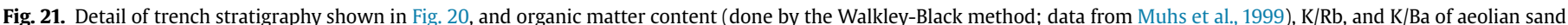

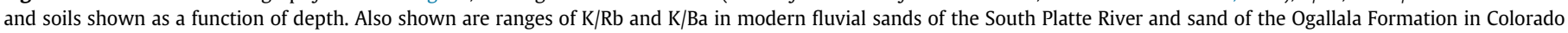
(data from Fig. 19).

\subsection{Sand transport pathways in the southwestern USA and origin of the Parker dunes, Arizona}

Debate about the origin of the Parker dunes of western Arizona has centered on local vs. distal sources of sand. Metzger et al. (1973, p. 26) hypothesized that dunes in the Parker area were derived simply from alluvium of the nearby Colorado River to the west. In contrast, a concept that emerged from remote sensing studies of the Mojave and Sonoran Deserts of southeastern California and adjacent Arizona is that there may be distinct sand transport pathways from basin to basin within the region (Zimbelman et al., 1995). The latter workers recognized two pathways of sand transport through topographic basins by analysis of Landsat imagery and dune geomorphology. Lancaster and Tchakerian (1996) expanded the sand transport pathway concept, and Clarke and Rendell (1998) added a third pathway. One of the hypothesized pathways proposed by Zimbelman et al. (1995) is a northwest-to southeasttrending route from the Cadiz and Danby dune fields in California, across the Colorado River, and over to the Parker dunes (Fig. 10). Thus, in contrast to the simple explanation of Metzger et al. (1973), this mechanism would imply that the Parker-area dunes are essentially extensions of the Cadiz and Danby dune fields and would require aeolian sand transport across the Colorado River valley. Transport of aeolian sand from California across the
Colorado River valley to Arizona would presumably have taken place during very arid periods of the Quaternary, when river discharge was essentially zero and the valley would have been dry, at least seasonally. In two later studies, Zimbelman and Williams (2002) and Muhs et al. (2003) tested this hypothesis with mineralogical and geochemical studies. Both studies reported higher quartz contents in the Parker dunes compared to the Cadiz and Danby dunes. The quartz contents and geochemistry of the Parker dunes are, however, very similar to Colorado River sediments that are immediately to the west of the dune field. Both studies concluded that the simpler explanation of Metzger et al. (1973) for a Colorado River origin for the Parker dunes was more likely.

One flaw in the interpretations of the studies by Zimbelman and Williams (2002) and Muhs et al. (2003), however, is that it is possible that long-distance transport of sand to the east and/or a longer history of dune activity within the Parker dunes could have resulted in feldspar depletion within the Parker dunes. This mechanism could explain the difference in mineralogical composition between the Cadiz/Danby and Parker dunes without having to appeal to different sources for the two dune fields. Examination of $\mathrm{K} / \mathrm{Rb}$ and $\mathrm{K} / \mathrm{Ba}$ values in the Cadiz, Danby, and Parker dunes shows, however, that while the Cadiz and Danby dunes have similar compositions, the Parker dunes have distinctive $\mathrm{K} / \mathrm{Rb}$ and $\mathrm{K} / \mathrm{Ba}$ compositions, indicating K-feldspar populations that were derived 
(a)

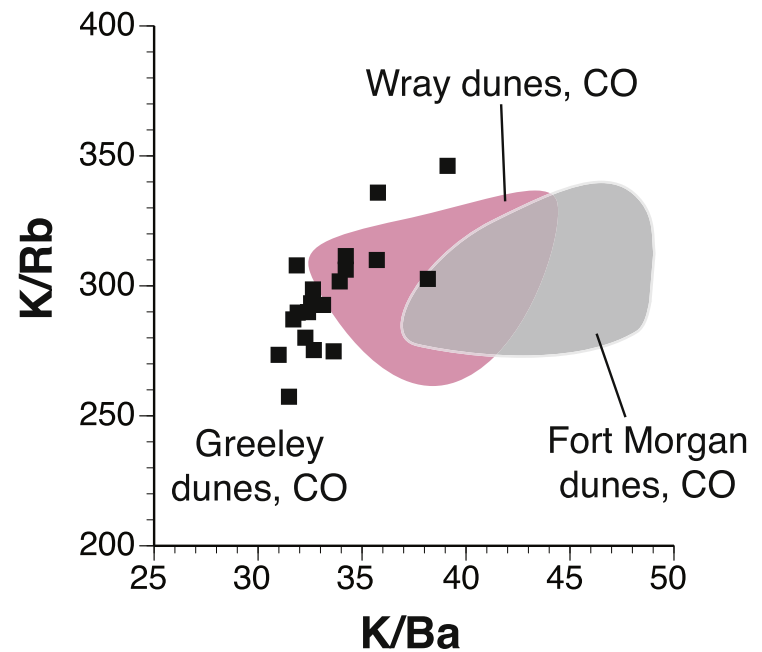

(c)

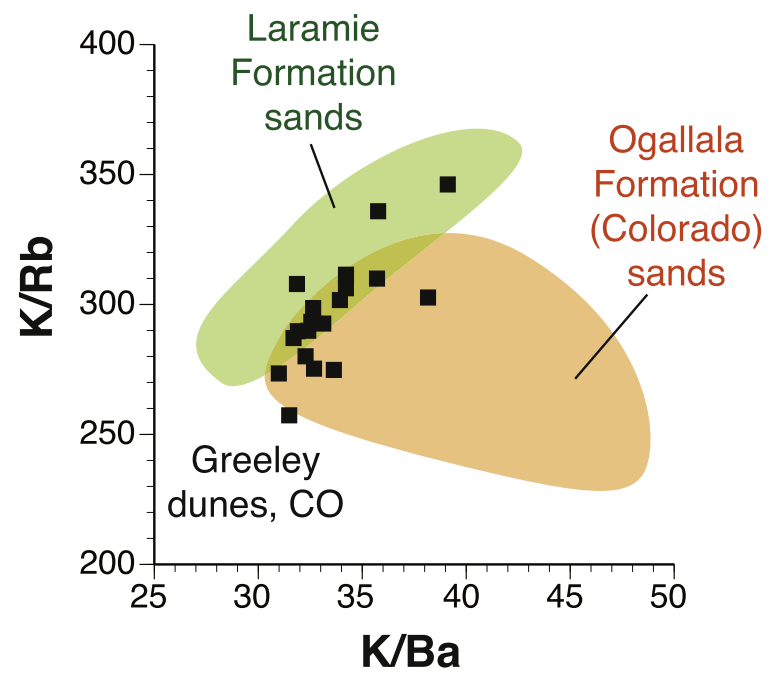

(b)

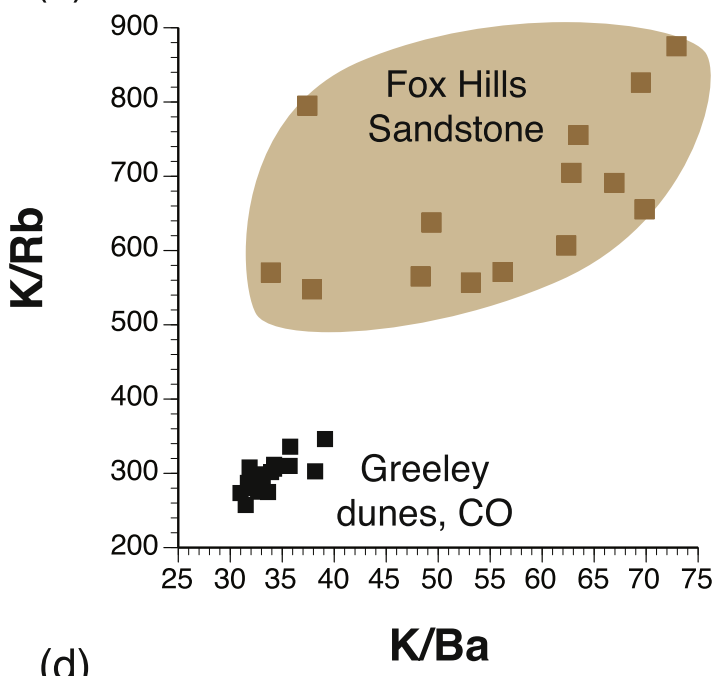

(d)

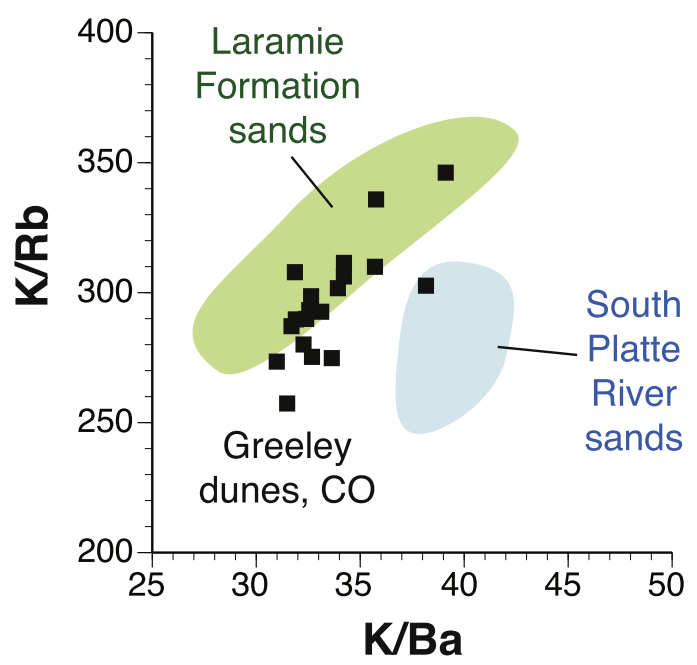

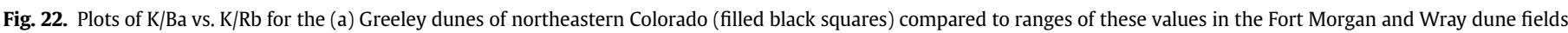

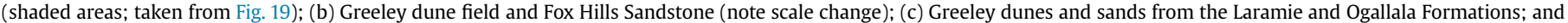

(d) Greeley dunes, South Platte River sands, and sands from the Laramie Formation.

from different sources (Fig. 12). Thus, the interpretations of Zimbelman and Williams (2002) and Muhs et al. (2003) of a Colorado River influence are still supported by the K/Rb and K/Ba data.

An unexpected result, however, is that while many of the Parker dune sands have $\mathrm{K} / \mathrm{Rb}$ and $\mathrm{K} / \mathrm{Ba}$ compositions close to those of Colorado River sands, other sands in this dune field, particularly in the Cactus Plain area, have $\mathrm{K} / \mathrm{Rb}$ and $\mathrm{K} / \mathrm{Ba}$ compositions that are intermediate between those of the Colorado River and Bouse Wash, a local tributary to the Colorado River (Figs. 11 and 12). Thus, while the interpretations of Zimbelman and Williams (2002) and Muhs et al. (2003) that the Parker dunes are not derived from the Cadiz and Danby dunes is retained from the present analysis, the inference that the Colorado River is the sole source of the Parker dunes is apparently an oversimplification. Further, the degree of influence of Bouse Wash sands on dune composition is variable; dunes on La Posa Plain, south of Bouse Wash, fall closer to the compositional field of Colorado River sands (at least those near Yuma), whereas dunes on the Cactus Plain, particularly the eastern part, fall somewhat closer to the compositional field of Bouse Wash (Fig. 12b, c, d). These observations are consistent with dune-forming winds from the southwest, based on the orientations of linear and parabolic dunes (Fig. 11). Thus, Bouse Wash emerges as a probable local, secondary source for at least some of the Parker dunes. The new analyses presented here, while supporting some previous interpretations of the importance of the Colorado River as a source of dune sand, also show that local sources of alluvium can be important. This new finding is not apparent from the element concentration data given in Zimbelman and Williams (2002) and Muhs et al. (2003).

\subsection{Origin of dunes in the Southern High Plains, Texas and New Mexico}

The origin of dunes on the Southern High Plains of Texas and New Mexico has been debated for more than seven decades. Hefley and Sidwell (1945) proposed that aeolian sands in at least some of the dune fields of the Southern High Plains were derived from underlying "Tertiary and early Pleistocene deposits," which can be interpreted to mean the Ogallala Formation and Blackwater Draw Formation, respectively. In one of his summary statements of 


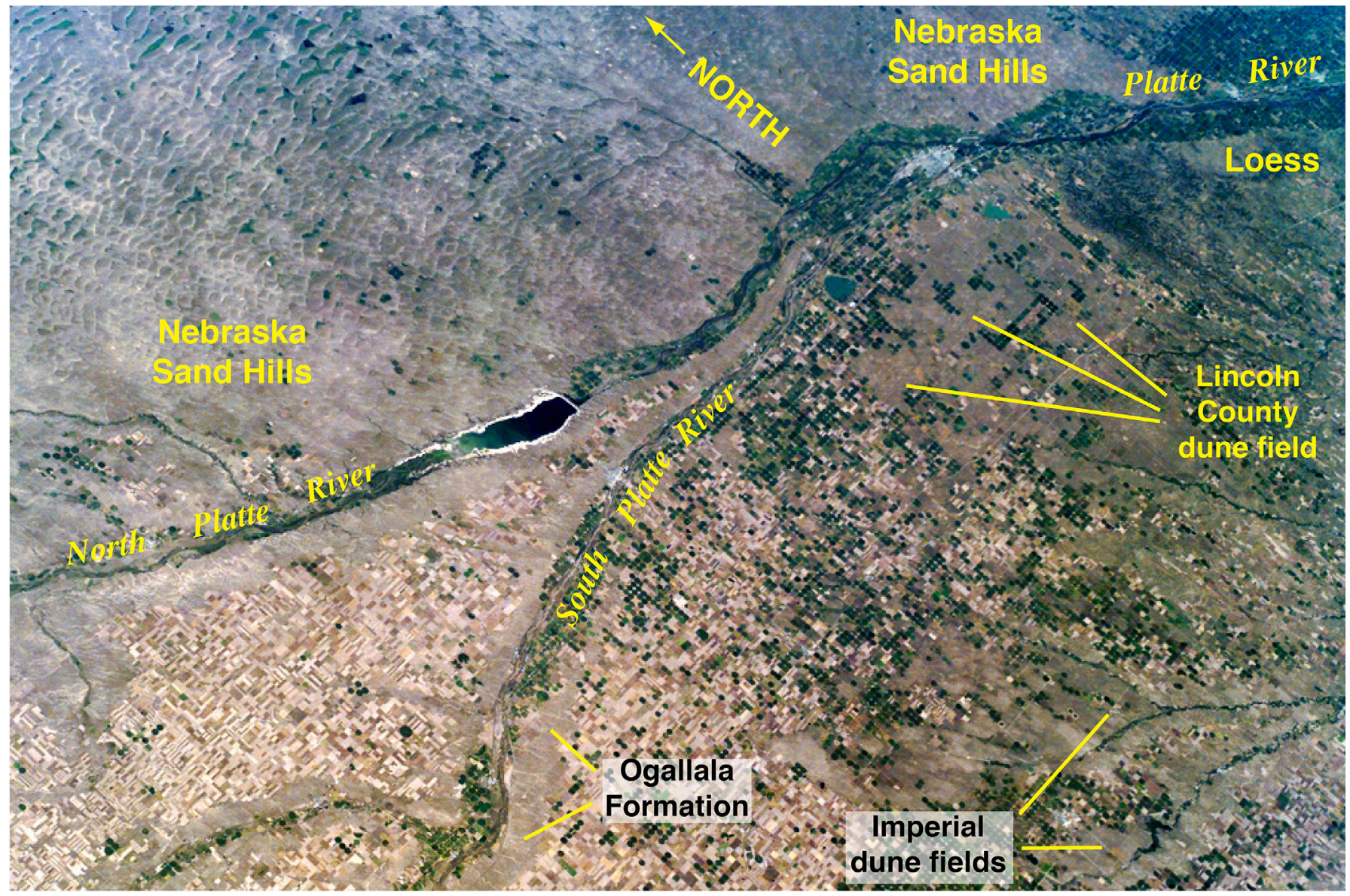

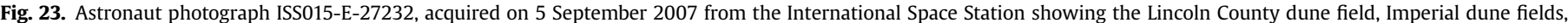

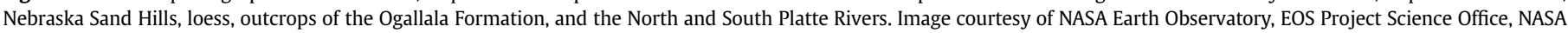
Goddard Space Flight Center.

decades of work, Lugn (1968) stated categorically that the older Tertiary Ogallala Formation was the main source of Pleistocene and Holocene aeolian sand for the entire Great Plains region, from Nebraska to Texas. In still another view, Green (1961), Hawley et al. (1976), and Carlisle and Marrs (1982) suggested that the dune fields of the Southern High Plains owed their origins to funneling of winds through reentrants in the High Plains escarpment, a northsouth-trending valley side cut on the Ogallala Formation, parallel to the Pecos River. An important implication of this model is that sediments of the Pecos River valley were the main sources of aeolian sand in dune fields to the east.

The Ogallala Formation was not considered by Muhs and Holliday (2001) to be a very likely source for Southern High Plains dune sands. Although the Ogallala Formation is extensive in the Southern High Plains of Texas and New Mexico, the formation has a well-cemented pedogenic calcrete caprock that is very resistant to erosion. Indeed, part of the reason that the Southern High Plains exists as a distinctive, high-elevation mesa is the resistance of this well-cemented calcrete caprock. Geochemical data presented by Muhs and Holliday (2001) support an interpretation of the Blackwater Draw Formation as a likely source for many of the Southern High Plains dune fields. These workers concluded that the Pecos River is not a particularly important source for dune fields of the Southern High Plains.

Muhs and Holliday (2001) also showed, however, that Southern High Plains aeolian sands may be the most quartz-rich of any dune sands in North America, consistent with major element geochemistry (Muhs, 2004; see also Fig. 4b). This makes assessment of the origin of Southern High Plains dunes particularly challenging. As with the Algodones, East Mesa, Yuma Desert, and Parker dunes, maturing of the Southern High Plains dunes from what was originally a feldspar-rich source sediment could still be consistent with a Pecos River source, if only element concentration data were used. Nevertheless, the new K/Rb and K/Ba data presented here indicate that the Muleshoe dune field and Lea-Yoakum dune field sands (with some exceptions) have compositions much closer to that of sands in the Blackwater Draw Formation compared to that of Pecos River sands (Fig. 14). Thus, despite the issue of possible mineralogical maturing being a flaw in the interpretations of Muhs and Holliday (2001), their original conclusion is upheld by the present analysis.

There is an independent line of evidence that the Blackwater Draw Formation is the main source for aeolian sand, at least for the Muleshoe dune field. Sediments of the Blackwater Draw Formation, and particularly the paleosols within it, are dominantly aeolian sands with abundant clay and Fe-oxide coatings that give red to reddish-brown (2.5 YR to 5 YR) hues to the sediment (Holliday, 1989). In the western part of the Muleshoe dune field, Holocene dunes have mostly 5 YR hues, whereas dunes farther downwind have 7.5 YR hues, and those on the periphery of the eastern half of the dune field have 10 YR hues. Muhs and Holliday (2001) interpreted this trend in decreasing redness downwind to indicate that proximal aeolian sands inherit the red (5 YR) hues from Blackwater Draw source sediments. With further aeolian transport, red to 


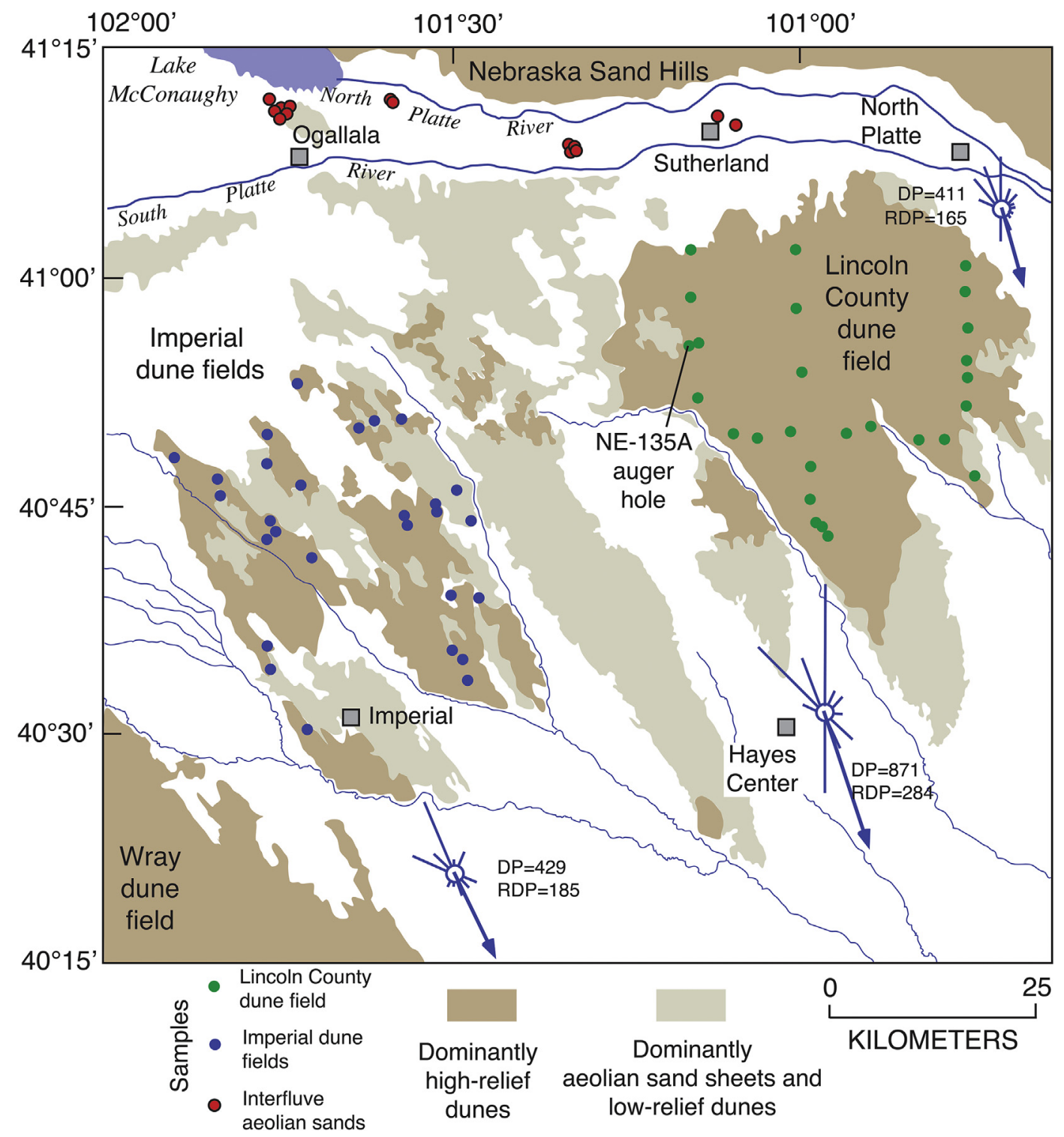

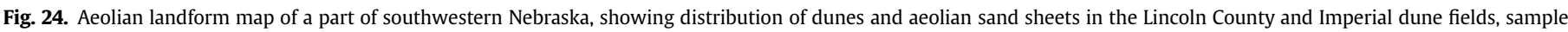

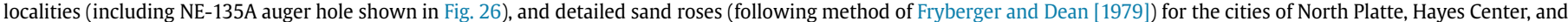

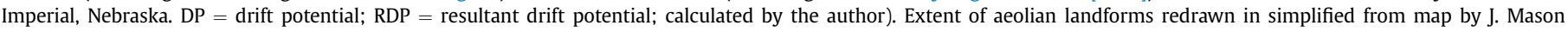

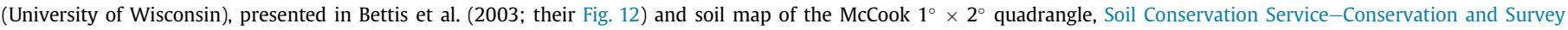
Division, University of Nebraska (1978).

reddish-brown clay and Fe-oxide coatings are abraded off, resulting in yellower hues (7.5 YR or 10 YR) in distal parts of the dune field. Decreasing clay and bulk Fe contents downwind are consistent with this trend (see Muhs and Holliday [2001], their Fig. 10, lower and Fig. 13, upper). It is interesting to note that the trend of a downwind decrease in dune reddening differs from what has been observed in many regions, where older, redder dunes are found downwind of a source (Walker, 1979; Gardner and Pye, 1981; Lancaster, 1989; Pye and Tsoar, 1990), although evidence to the contrary has also been reported (Roskin et al., 2012). Nevertheless, the dune color trends as well as the $\mathrm{K} / \mathrm{Rb}$ and $\mathrm{K} / \mathrm{Ba}$ data support an interpretation of the Blackwater Draw Formation as a major source for the Muleshoe dunes and probably some but not all of the LeaYoakum dunes. A remaining issue is identification of the source of sand in the Blackwater Draw Formation itself, a question that is beyond the scope of the present study.

\subsection{Origin of the Great Bend dunes, Kansas}

Determination of the origin of the Great Bend dunes in Kansas has been a particularly challenging task. Although the distribution of the dunes would seem to imply a straightforward Arkansas River origin, the modern, sand-transporting wind direction is from the south and the orientations of Holocene dunes indicate paleowinds from the south as well (Fig. 15). Smith (1940, p. 168) proposed that dunes in central Kansas had an Arkansas River valley origin by hypothesizing that northerly winds, opposite to the present, occurred during the last glacial period. In contrast, Stramel et al. (1958) suggested that erosion of sands that underlie late Quaternary loess, which in turn underlies the dune sands, could have been the source of sand, implying a southerly paleowind. However, Simonett (1960) pointed out that in most areas, the underlying lastglacial-age loess was too thick and covered too much of the older, underlying sand for the latter to have been a significant source for 
(a)

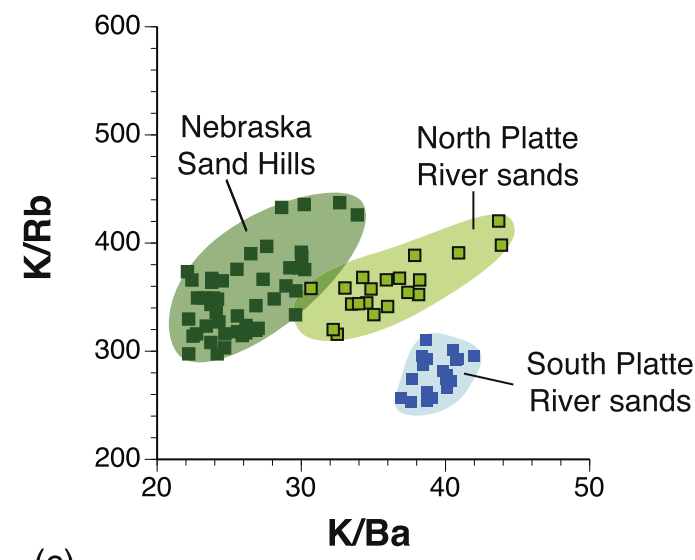

(c)

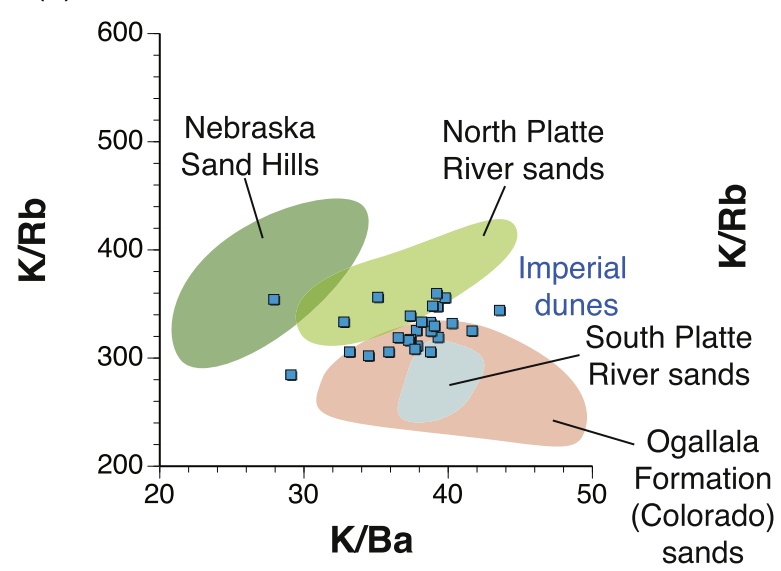

(b)

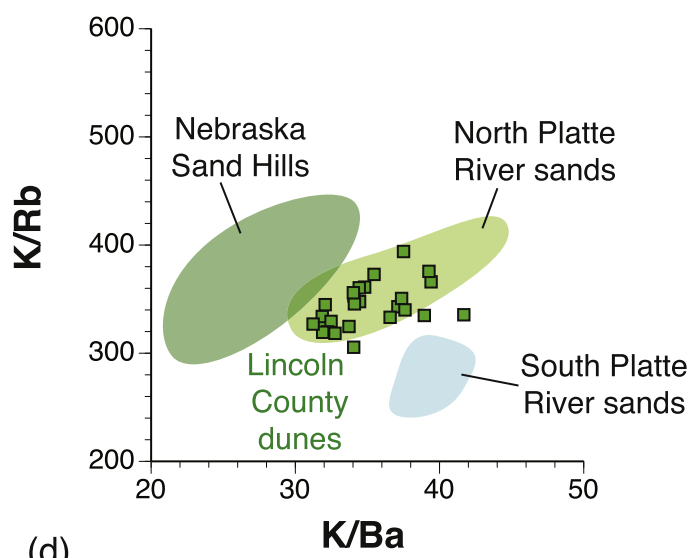

(d)

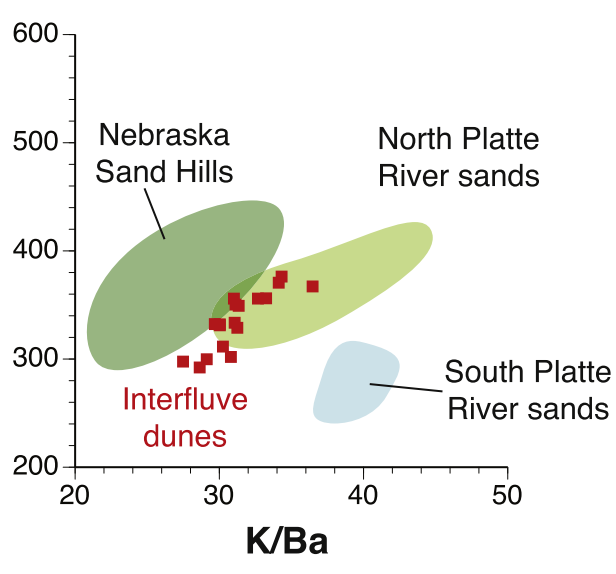

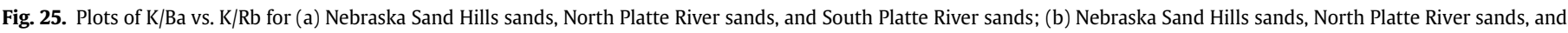

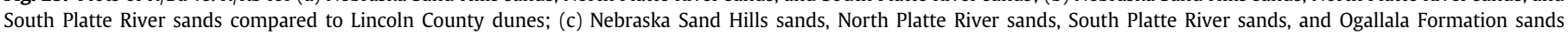
compared to Imperial dunes; and (d) Nebraska Sand Hills sands, North Platte River sands, and South Platte River sands compared to interfluve dunes.

the younger dunes. Simonett (1960) agreed with Smith (1940) that the dunes formed from an Arkansas River valley source under lastglacial paleowinds from the north. Smith (1940) and Simonett (1960) conducted their studies before much was known about the age of dunes in Kansas. Thus, their hypothesis of a last-glacial age for the time of dune building was not constrained by the chronology that now exists. Stratigraphic and radiocarbon studies by Arbogast (1996) and Arbogast and Johnson (1998) for the Great Bend dunes have shown that the latest periods of dune building date to the Holocene. Arbogast and Muhs (2000) pointed out that Pleistocene alluvium occurs to the south of the Great Bend dunes (Fig. 15b), as well as beneath it (Ross et al., 1991). Although this alluvium typically has well-developed soils with Bt, Btk, or Bk horizons, indicating little or no erosion, it is rich in sand-sized particles and some parts of it could conceivably have been sources of aeolian sand when southerly winds prevailed.

Although Arbogast (1996) showed that the latest episodes of dune formation in the Great Bend area occurred in the late Holocene, there is a northwest-to southeast-diminishing $\mathrm{Ca}$ and $\mathrm{Sr}$ content in dune sand. Arbogast and Muhs (2000) interpreted these trends to be from aeolian abrasional depletion of carbonate minerals. These investigators speculated that initial aeolian sand deposition in the Great Bend area came from the Arkansas River, perhaps during the early or mid-Holocene, when northwesterly winds prevailed during a period of greater residence of dry, Pacificderived air masses over the region. They proposed that the late Holocene dunes developed later, from reworking of the earlier
Holocene sands, under the present wind regime, which is southerly. $\mathrm{K} / \mathrm{Rb}$ and $\mathrm{K} / \mathrm{Ba}$ values in the late Holocene Great Bend dune sands overlap the field for these values for modern Arkansas River alluvium very closely, but also differ only slightly from those found in the older, Pleistocene alluvium found to the south of the dune field (Fig. 14c and d). Given its geographic proximity to the Arkansas River and the lack of other major drainages nearby, it is quite likely that the Pleistocene alluvium to the south of the Great Bend dunes was deposited originally by the Arkansas River. This is certainly consistent with the geomorphology of the region and would explain the similar composition of this older alluvium to modern Arkansas River alluvium. Nevertheless, the composition of the older alluvium differs just enough from modern Arkansas River alluvium that it is possible to distinguish these two sources. Of the two sources, the composition of late Holocene dunes is closer to modern Arkansas River alluvium. Thus, the sequence of events hypothesized by Arbogast and Muhs (2000) still has validity, but given the small difference between the two competing sources, the results presented here indicate that further research in this dune field would be valuable.

\subsection{Origin of northeastern Colorado dune fields}

As discussed earlier, Lugn (1968) stated that there was likely a single source, the Tertiary Ogallala Formation, for aeolian sand in the Great Plains region, including northeastern Colorado. Almost two decades later, Hunt (1986) also proposed that dunes in 
NE-135A auger

hole, Nebraska:

\section{Organic matter $(\%)$}

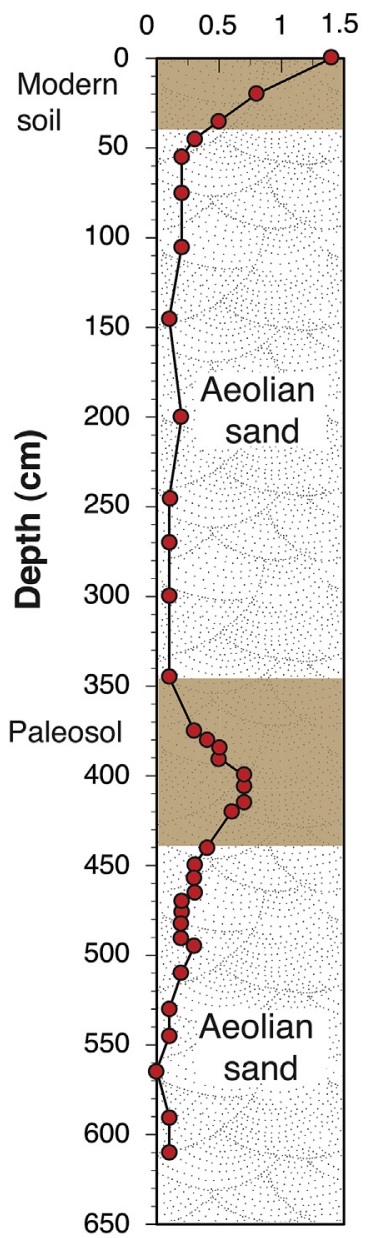

$\mathrm{K} / \mathrm{Rb}$

$\mathrm{K} / \mathrm{Ba}$

$\mathrm{K} / \mathrm{Rb}$

$\mathrm{K} / \mathrm{Ba}$
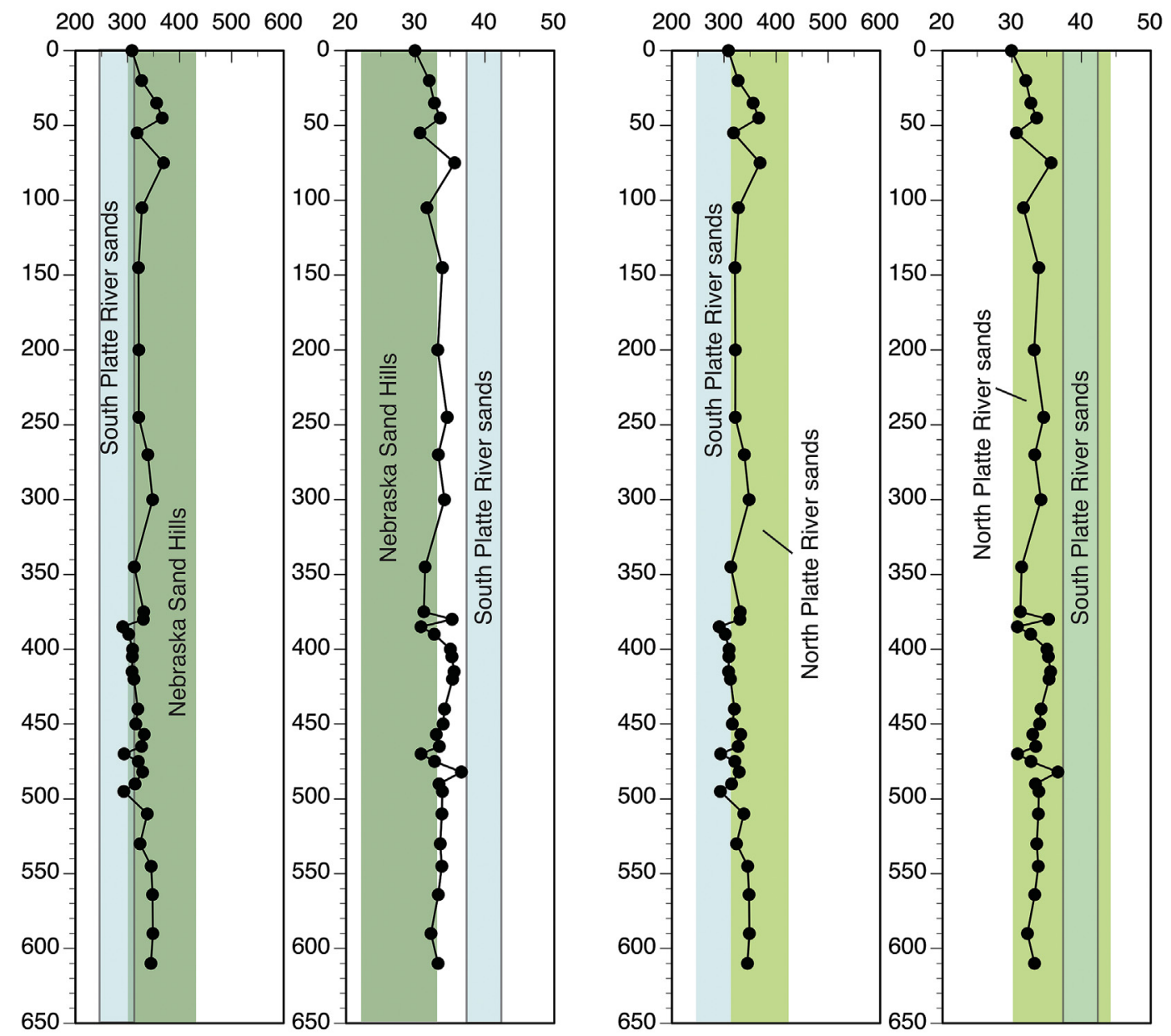

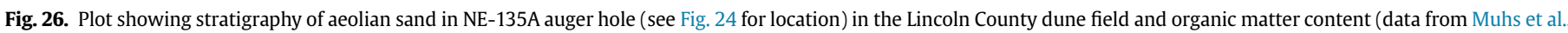

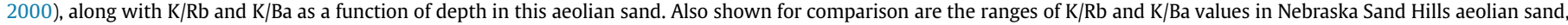
South Platte River sand, and North Platte River sand.

northeastern Colorado were derived from "Tertiary formations," which can be interpreted to mean the Ogallala Formation. In contrast to Lugn (1968) however, Hunt (1986) also thought there could have been contributions from the South Platte River to northeastern Colorado dune fields, at least during glacial periods of the Quaternary. In the central Great Plains region of northeastern Colorado and southwestern Nebraska, the Ogallala Formation is a dominantly fluvial deposit that is composed of silt, sand, and gravel derived from granitic, sedimentary, and volcanic rocks. Locally, it also contains volcanic ash beds (Scott, 1978). The unit forms broad, flat uplands, as is the case in the Southern High Plains discussed earlier, due in part to cementation in its upper part by pedogenic calcium carbonate. Despite the presence of this protective calcrete caprock, valley sides cut in the Ogallala Formation show that much of the formation is uncemented and can provide unconsolidated sediment to first-order drainages, at least in northeastern Colorado. This sediment has, therefore, the potential of being deflated by the wind under favorable circumstances. Nevertheless, in contrast to Lugn (1968) and Hunt (1986), Muhs (1985), Madole (1995), and Muhs et al. (1996) favored the South Platte River as the main source of sand for the Fort Morgan dune field of northeastern Colorado.

Using $\mathrm{K} / \mathrm{Rb}$ and $\mathrm{K} / \mathrm{Ba}$, it is possible to reassess the origin of the
Fort Morgan dune field. Results indicate that sands of the Laramie Formation do not likely have an important influence on the Fort Morgan dunes (Fig. 19c). It is more difficult to make a rigorous assessment of two of the other possible source sediments (South Platte River sands and Ogallala Formation sands), however, because their compositions overlap (Fig. 19b). While some samples from this dune field could be derived from South Platte River sands, the same samples (as well as others) could be derived from the Ogallala Formation (Fig. 19c). Furthermore, some Fort Morgan dune samples fall outside the fields of all source sediments considered. Samples with the highest K/Ba values are those in the westernmost part of the dune field, suggesting the possibility that there is another sand source that needs to be identified.

Muhs et al. (1996) concluded that the South Platte River was also the main source for aeolian sands of the Wray dune field. There is a large, dune-free area between the eastern part of the Fort Morgan dune field and the northwestern portion of the Wray dune field (Fig. 16). This area has either Tertiary Ogallala Formation bedrock or loess over bedrock exposed at the surface (Scott, 1978). Although the aeolian-sand-free zone would seem to rule out a South Platte River origin for the Wray dunes, Muhs et al. (1996) interpreted this area as a zone of sediment bypassing (Kocurek and Lancaster, 1999), 


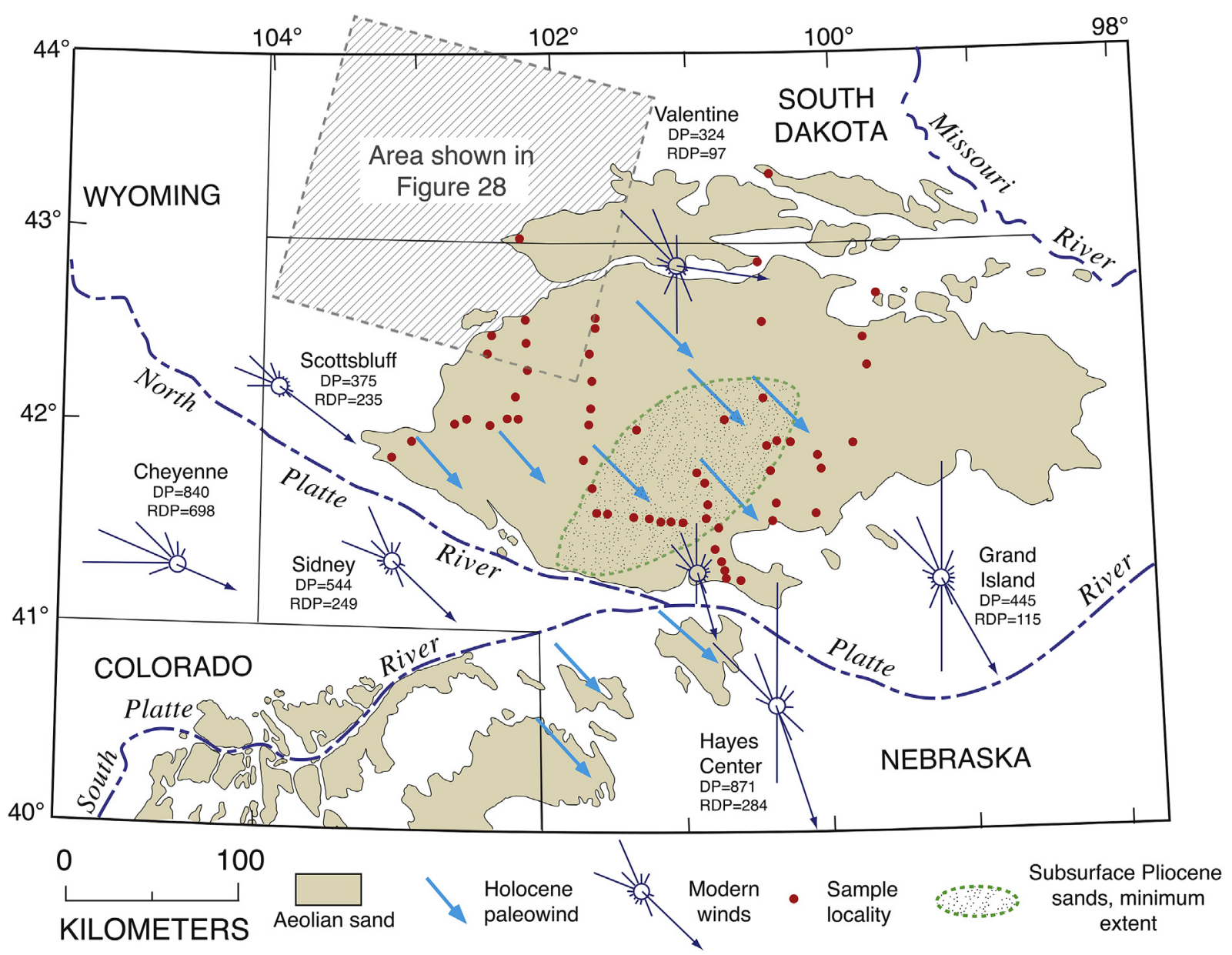

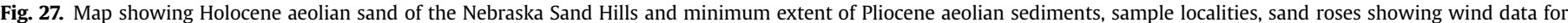

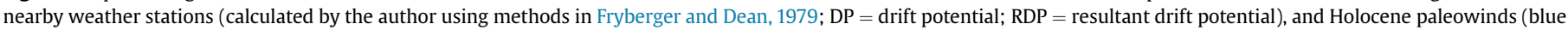

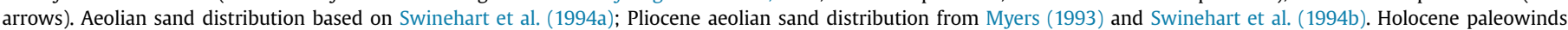

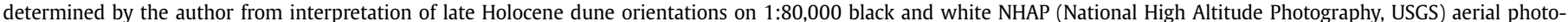

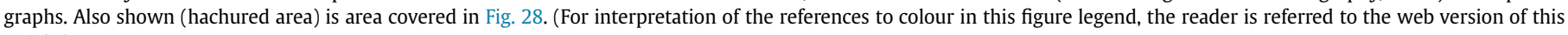
article.)

whereby sediment is transported across a part of the landscape, but there is no net accumulation there. This hypothesis may still be viable, at least for the late Holocene, considering that many of the Wray dune samples fall within the range of South Platte River sands (Fig. 19d). Nevertheless, not all of them do, and those that do not all plot within or near the field for the Ogallala Formation, a local source immediately upwind of the Wray dune field (Fig. 18). Furthermore, examination of K/Ba values in a thick vertical section through one of the Wray dunes shows that only a couple samples fall within the K/Ba range of South Platte River sands, and the rest fall within the range of $\mathrm{K} / \mathrm{Ba}$ values in the Ogallala Formation (Fig. 21). These observations would imply that Ogallala Formation bedrock may be more important to the origin of the Wray dune field than previously thought, supporting the original hypotheses of Lugn (1968) and Hunt (1986), and without having to appeal to a history of sediment bypassing. Still, the volume of sediment within the Wray dune field is significant and it is difficult to imagine a bedrock source supplying much or all of this sand within a timeframe as short as the late Holocene, unless one appeals to considerable reworking of Pleistocene sand. More studies are needed to assess this issue.

The origin of the Greeley dune field in northeastern Colorado has been enigmatic (Figs. 16 and 17). Although this dune field is adjacent to the South Platte River, an obvious candidate for a sand source, it is north of the river and Holocene parabolic dune orientations indicate very clearly that the most recent dune-forming paleowinds were from the northwest (Fig. 17). There is, however, no other major river system situated to the north of the Greeley dune field that constitutes an apparent sand source.

Madole (1995) speculated that bedrock formations to the north of the South Platte River could be the source of the Greeley dunes. A number of bedrock units in this area can be considered as possible sources (Fig. 17) and some are more likely candidates than others. The Cretaceous Fox Hills Sandstone has a very limited areal extent at the surface and is extremely well cemented, making it an unlikely source. The Cretaceous Laramie Formation is sand-rich and has a broad spatial extent to the north of the Greeley dunes; in addition, much of it has weathered to a loose, sandy residuum. In northern Colorado, the Tertiary White River Group is extensive (Fig. 17), but is primarily a siltstone. Unlike southeastern Wyoming, the Tertiary Arikaree Formation crops out only in a few places in northern Colorado; indeed, its spatial extent is too limited to show on Fig. 17. In contrast, the Tertiary Ogallala Formation has an extensive area of outcrop at the surface in Colorado, north of the Greeley dune field.

Consistent with late Holocene dune orientations indicating 


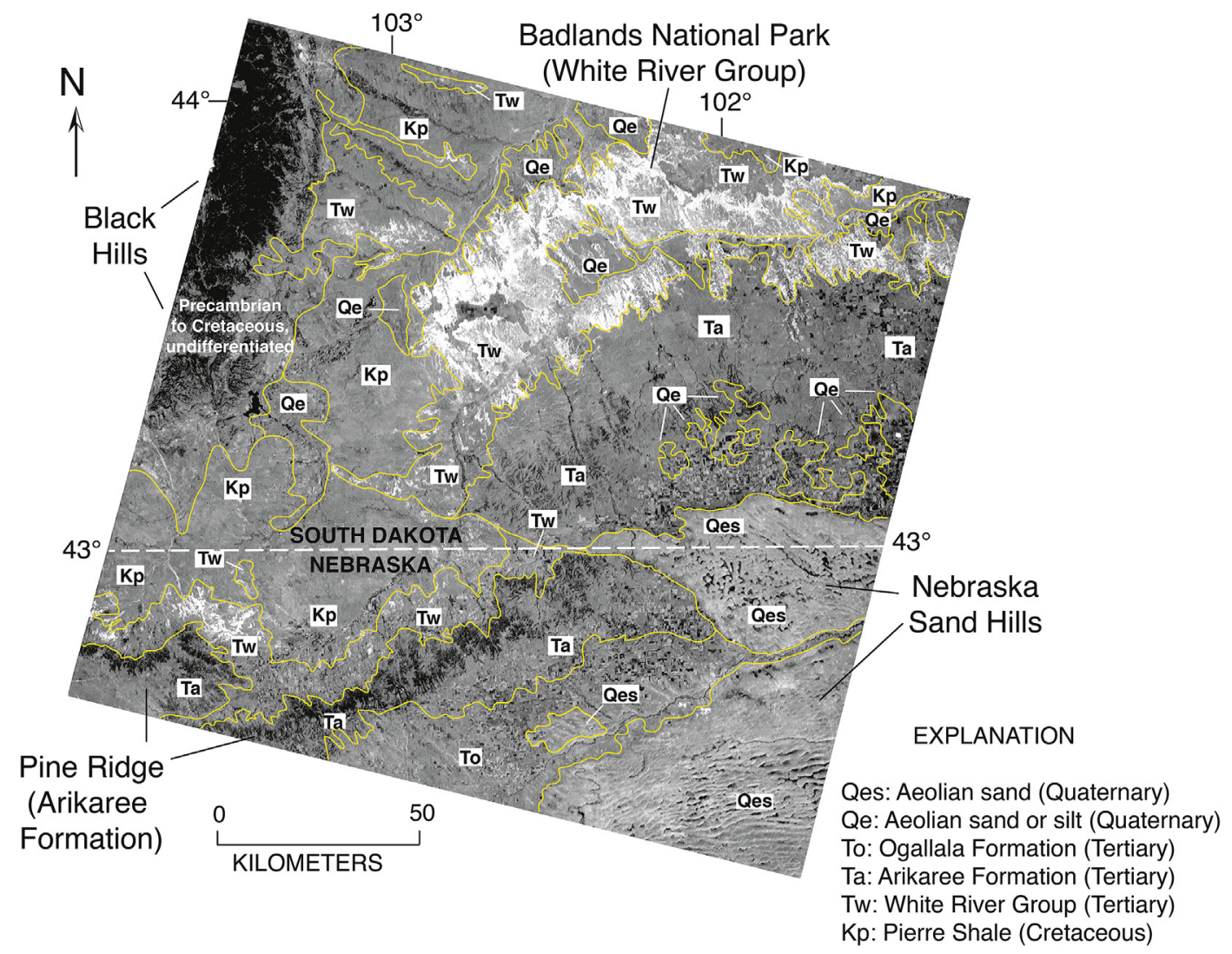

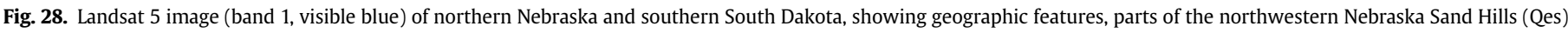

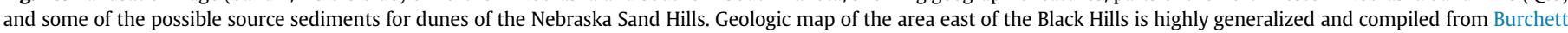
(1986) and Martin et al. (2004). Diagram is very slightly modified from Muhs et al. (2008).

northwesterly paleowinds (and therefore a source that is upwind of the South Platte River), K/Rb and K/Ba values in the Greeley dunes do not fall within the field defined by South Platte River sands (Fig. 22d). Very high $\mathrm{K} / \mathrm{Rb}$ and $\mathrm{K} / \mathrm{Ba}$ values indicate that the wellcemented and spatially limited Fox Hills Sandstone is not an important source for the Greeley dunes either (Fig. 22b). There is good agreement between the $\mathrm{K} / \mathrm{Rb}$ and $\mathrm{K} / \mathrm{Ba}$ composition of the Greeley dunes and the Ogallala Formation, and this formation crops out extensively in northern Colorado, upwind of the Greeley dunes (Fig. 22c). In many places, the Laramie Formation is poorly consolidated, has abundant sand-sized residuum that has weathered from it, and many streams, tributary to the South Platte River, traverse surface outcrops of the formation, providing loose, readily available sediment. $\mathrm{K} / \mathrm{Rb}$ and $\mathrm{K} / \mathrm{Ba}$ in the Greeley dunes also show good agreement with much of the compositional range of the Laramie Formation. Based on these observations, the Laramie Formation or residuum from it and the Ogallala Formation are the most likely source or sources for the Greeley dunes. If this is correct, it is significant, as it demonstrates that bedrock or bedrock residuum, in addition to alluvium, can be an important source of aeolian sand, which may also be the case for the Wray dune field.

\subsection{Origin of dune fields in southwestern Nebraska}

Given that the Lincoln County and Imperial dune fields are situated south of the South Platte River, a simple explanation, similar to the Fort Morgan dune field, is that both of these Nebraska dune fields are derived from fluvial sediments from the adjacent river valley. In a novel hypothesis, however, Swinehart and Loope (1992) and Loope and Swinehart (2000) proposed that the Lincoln County dune field is a remnant of a former, larger Nebraska Sand Hills. They hypothesized that aeolian sand from the Nebraska Sand Hills may have filled the North and South Platte River valleys during a dry climatic phase (i.e., one of little or no river flow) sometime during the last glacial period. A giant dune dam would have been created by this aeolian sand movement, which in turn would have generated a large lake or series of lakes upstream during later periods of higher fluvial discharge. Later, the dam would have been breached, isolating the Lincoln County dune field (and perhaps the Imperial dune field) south of the South Platte River. Prior to the presentation of this hypothesis, Diffendal and Leite (1989) reported widely distributed, diatomaceous lake sediments in tributaries of the North Platte River. A paleosol at the top of a 3-m-thick lacustrine sequence, $\sim 45 \mathrm{~m}$ above the present floodplain, yielded a radiocarbon age of $\sim 12,500$ calibrated ${ }^{14} \mathrm{C}$ yr B.P. (see Fig. 5 in Muhs et al., 2000). These lake sediments could have been deposited while the hypothesized giant dune dam was in place. The concept of a dune dam in this region is not unprecedented: Loope et al. (1995) established that dune dams had been present in the late Quaternary in the larger, main body of the Nebraska Sand Hills.

Winspear and Pye (1996) used mineralogy and major element concentrations to test Swinehart and Loope's (1992) hypothesis of a Nebraska Sand Hills source for the Lincoln County dune field. Their data show quartz and K-feldspar contents in the Lincoln County dunes that are intermediate between those in the Nebraska Sand Hills and South Platte River sands, but $\mathrm{SiO}_{2}$ and $\mathrm{K}_{2} \mathrm{O}$ contents (that reflect quartz and $\mathrm{K}$-feldspar, respectively) in the Lincoln County dunes that are closer to South Platte River sands. They concluded that it was more likely that the Lincoln County dune field was derived from South Platte River sediments. Muhs et al. (2000) also 
(a)

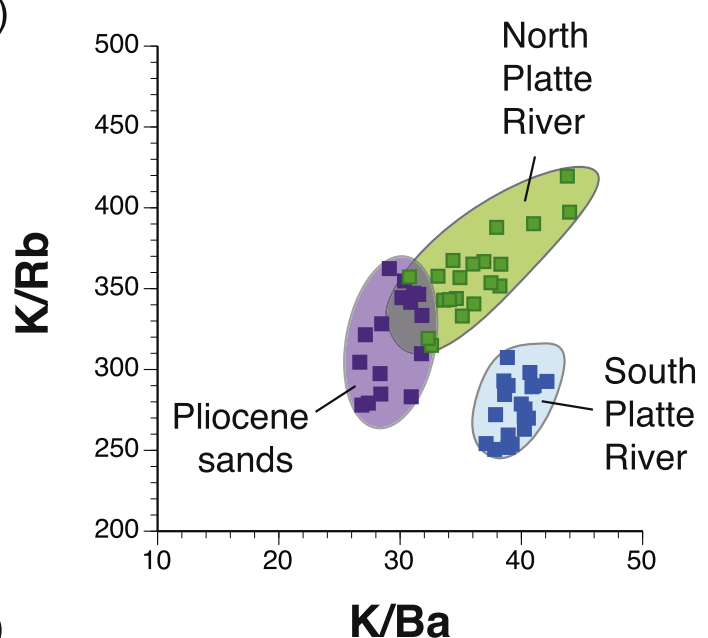

(c)

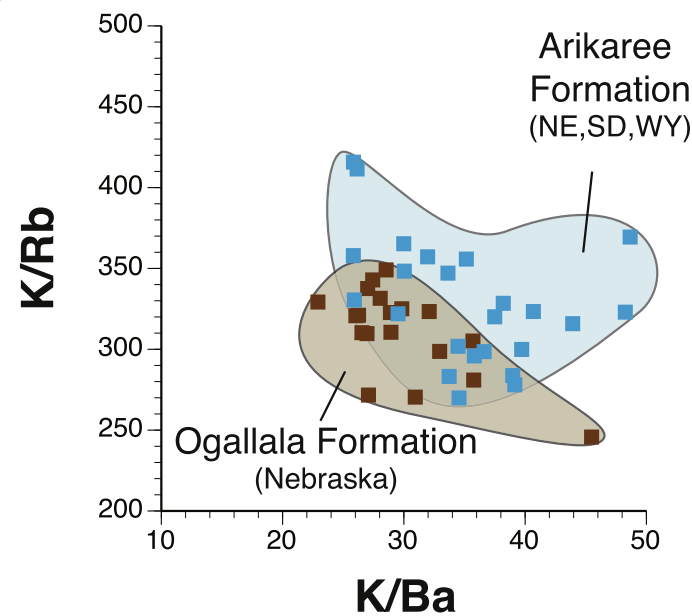

(b)

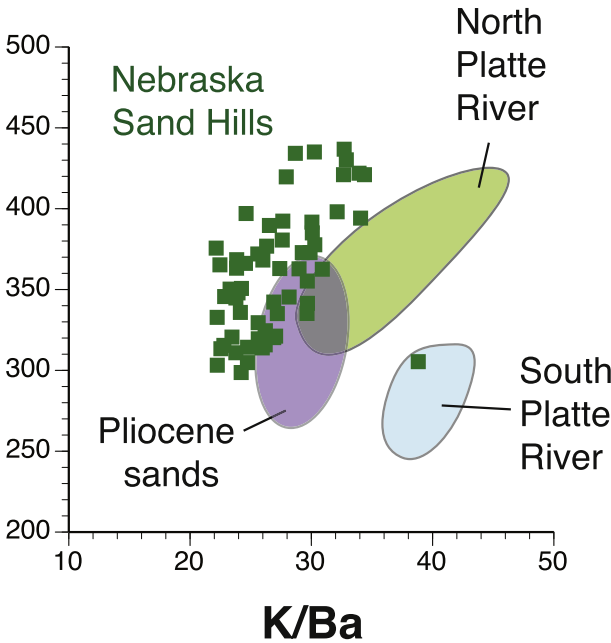

(d)

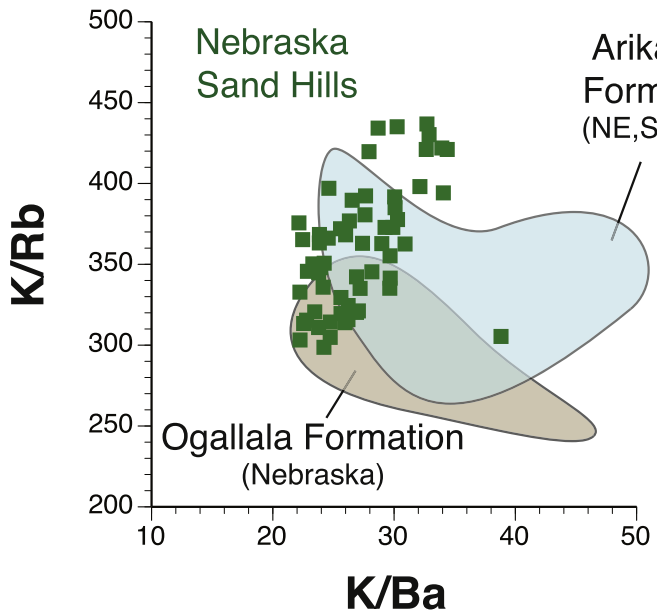

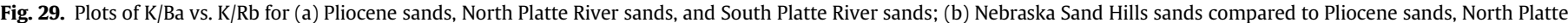

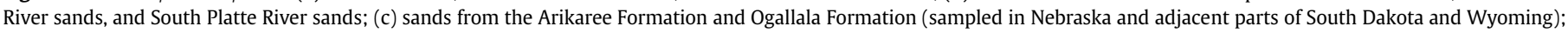
and (d) Nebraska Sand Hills sands compared to the Arikaree and Ogallala Formations. NE, Nebraska; WY, Wyoming; SD, South Dakota.

tested the hypothesis of Swinehart and Loope (1992) using concentrations of $\mathrm{K}, \mathrm{Rb}$, and $\mathrm{Ba}$ (not $\mathrm{K} / \mathrm{Rb}$ and $\mathrm{K} / \mathrm{Ba}$ values) and reported that the Lincoln County and Imperial dune fields have concentrations intermediate between the Nebraska Sand Hills, which is relatively quartz-rich (see Fig. 5c), and the Fort Morgan dune field in Colorado, which is K-feldspar-rich (Muhs et al., 1996). The intermediate values of $\mathrm{K}, \mathrm{Rb}$, and Ba concentrations in the Lincoln and Imperial dune fields were interpreted to indicate that these aeolian sands formed from a mix of Nebraska Sand Hills-derived sand (as per the Swinehart and Loope [1992] hypothesis) and South Platte River sands (as per the Winspear and Pye [1996] hypothesis).

The Lincoln County dunes have $\mathrm{K} / \mathrm{Rb}$ and $\mathrm{K} / \mathrm{Ba}$ compositions that are intermediate between those of the Nebraska Sand Hills and the South Platte River, but also are almost identical to those of North Platte River sands (Fig. 25b). The Imperial dunes also have an intermediate composition, but fall somewhat closer to the field defined by South Platte River sands (Fig. 25c). In addition, many of the Imperial dune samples fall within the compositional field defined by the Ogallala Formation (based on samples of this formation collected in Colorado). Aeolian sand on the interfluve between the North Platte River and South Platte River also has an intermediate composition, but falls somewhat closer to the field defined by the Nebraska Sand Hills.

The intermediate composition of both the Lincoln County and
Imperial dunes rules out sole derivation from the South Platte River, which argues against the explanation of Winspear and Pye (1996). A simple explanation for the Lincoln County dunes is that they are derived entirely from sands of the North Platte River, which is supported by $\mathrm{K} / \mathrm{Rb}$ and $\mathrm{K} / \mathrm{Ba}$ data. With this explanation, however, aeolian sand would have to have been entrained by the wind in the North Platte River valley, transported over the interfluve to the south, and further transported across the South Platte River valley and south of it, without any subsequent additions of sand from the South Platte River valley itself. If aeolian sand transport across the South Platte River valley took place, it would likely have been during a time when there was very low discharge in both the North Platte River and the South Platte River. Under such conditions, therefore, it seems almost certain that sediment in the South Platte River valley would also be available for aeolian entrainment. Thus, the explanation of a sole North Platte River source, while simple geochemically, is quite complex geomorphically and does not seem likely. A more probable sequence of events is that of Swinehart and Loope (1992) and Muhs et al. (2000), where the Lincoln County dunes formed initially from what was once a more extensive (to the south) Nebraska Sand Hills. Subsequently, mixing of these sands with new inputs from the South Platte River resulted in sediments with an intermediate composition. The mixing of these two sources apparently took place early in the history of the Lincoln County 


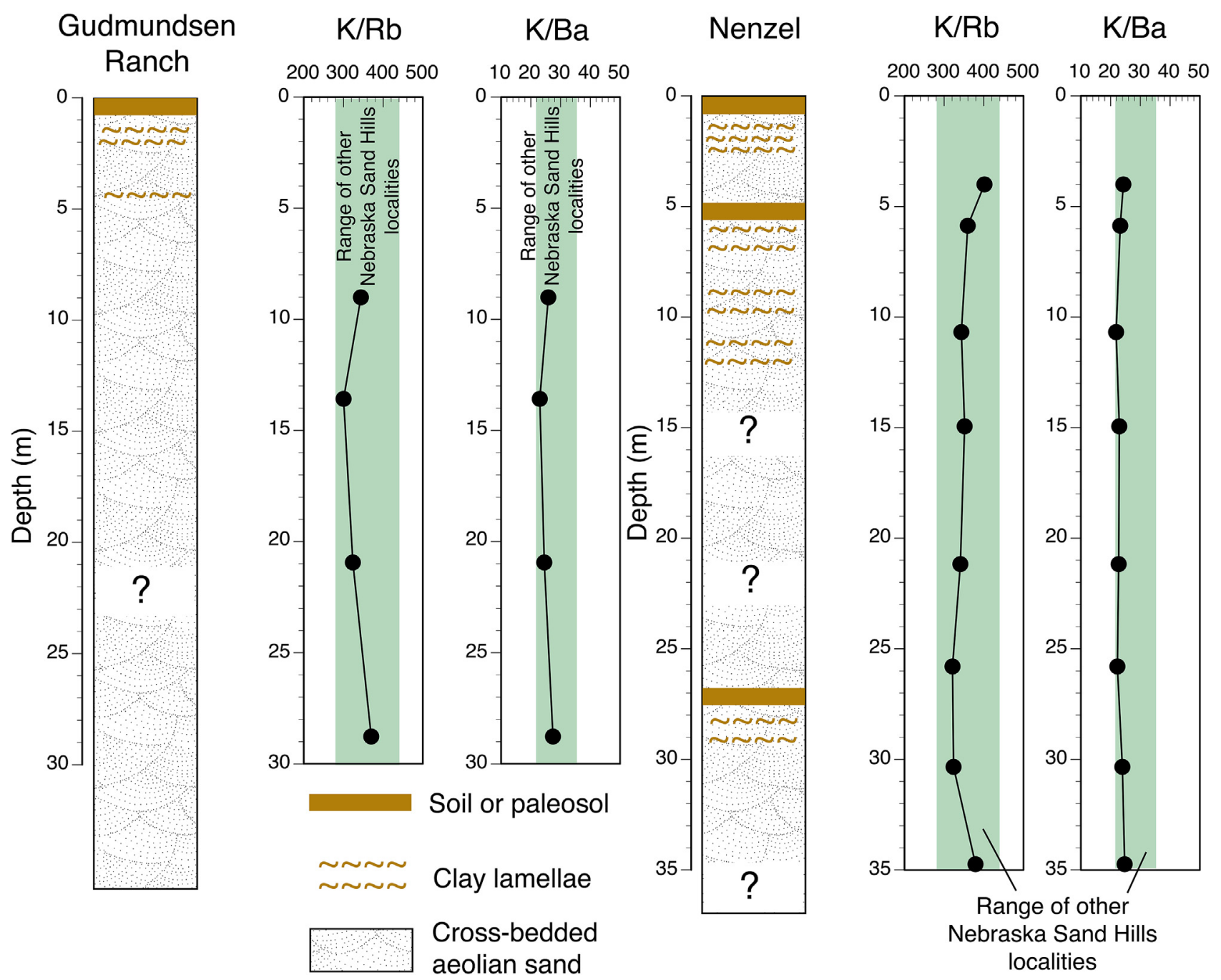

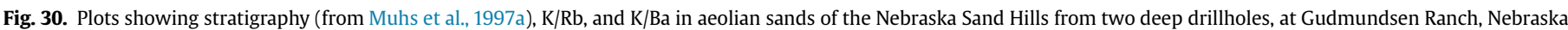

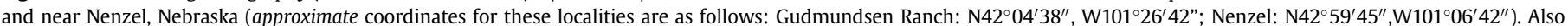

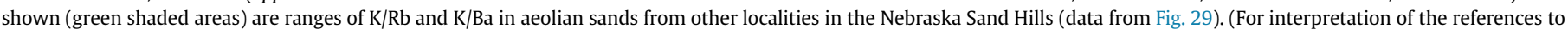
colour in this figure legend, the reader is referred to the web version of this article.)

dunes, as the same intermediate composition is found in both of two aeolian units, separated by a well-developed paleosol, visible in a $\sim 6$-m-thick section (Fig. 26).

The Imperial dunes can be explained in a similar fashion, although these sands plot closer to the South Platte River by comparison with the Lincoln County dunes. This is not surprising, however, as the Imperial dunes are situated somewhat farther away from the Nebraska Sand Hills compared to the Lincoln County dunes (Figs. 16, 23 and 24). In addition, as pointed out by Bettis et al. (2003) and Mason et al. (2011), the Imperial dunes lie downwind of Ogallala Formation bedrock that is buried by thin loess, and the formation is visible at the surface in Fig. 23. Many of the samples from the Imperial dunes fall outside the field defined by South Platte River sands but fall within the field defined by the Ogallala Formation. This observation suggests yet another possibility, which is some influence from a bedrock source for the supply of sand to the Imperial dunes, similar to what is reported here for the Wray dune field immediately to the west.

Finally, the discontinuous aeolian sand patches on the interfluve between the North Platte and South Platte Rivers provide some interesting supportive evidence for the origin of the Lincoln County dune field. The interfluve sands have $\mathrm{K} / \mathrm{Rb}$ and $\mathrm{K} / \mathrm{Ba}$ values that indicate they may have formed primarily from North Platte River sediments, but possibly with some input from the Nebraska Sand Hills. A mix of Nebraska Sand Hills sediment and North Platte River sands for the interfluve sands is consistent with the scenario sketched above for the origin of the Lincoln County dune field.

\subsection{Origin of the Nebraska Sand Hills}

Early investigators of the Nebraska Sand Hills did not have access to the tools available today for provenance studies, but offered hypotheses about the source of sand for this large dune field. As discussed earlier with regard to dune fields farther south in the Great Plains, Lugn $(1935,1962,1968)$ considered that both the Ogallala Formation and sediments reworked from it were the sources of both the Nebraska Sand Hills and loess to the southeast of the dune field. Thornbury (1965) articulated the same concept as Lugn $(1935,1962)$ for the origin of the Nebraska Sand Hills. In his brief summary, Thornbury (1965) also stated that the upper part of the Ogallala Formation is missing beneath the Sand Hills and the overall elevation of the dune field is lower than that of the High Plains region to the west, suggesting that major erosion occurred before the dune field formed. However, Thornbury (1965) did not 
provide any subsurface data to support these claims and it is not certain that such data even existed at the time he made these statements. Smith (1965) considered Lugn's (1962) concept to be oversimplified and stated that the Ogallala Formation is indurated in many places and is unlikely to have been a very important source for dune sand. However, based on more recent studies, Smith's (1965) statement about induration in the Ogallala Formation is actually oversimplified. Joeckel et al. (2014) conducted detailed sedimentological studies of the Ash Hollow Formation, which in the stratigraphic nomenclature for Nebraska is the youngest and most widespread unit, and one of the thickest within what is referred to in their paper as the Ogallala Group. These investigators point out (Joeckel et al., 2014, p. 79) that very fine to fine-grained sandstone is the predominant facies in this formation, it is well-sorted, and it is only weakly cemented. These observations are consistent with those made in the present study. In his study, Smith (1965) did speculate, however, that reworked Ogallala Formation sediments were a more likely source, although to be fair, Lugn $(1935,1962)$ also appealed to reworked Ogallala Formation sediments as a source. Smith (1965) also speculated that Pleistocene sediments in Nebraska, including the Nebraska Sand Hills, could have had sources farther west, without specifics about what these sources were or what evidence there was for this hypothesis. Reed (1968) also considered that unconsolidated Pleistocene sediments, reworked from the Ogallala Formation, were a likely source for the Sand Hills. Wright (1970) extended this argument further by pointing out that with time, an eroding Ogallala Formation surface would have been buried by aeolian sand, and further dune field growth would have to come from sources farther to the northwest, such as the White River Group. Although this idea is intriguing, it is problematic in that the White River Group is dominated by silt, not sand. Warren (1976) considered, on the basis of particle size data, that underlying fluvial sands were the source of the dunes, but was not specific as to where these sediments came from. Swinehart (1990) proposed that fluvial sands of Quaternary and Pliocene age, beneath the Sand Hills, were the primary sources of sand, along with some direct contributions from the Ogallala Formation. Winspear and Pye (1996) analyzed fluvial sands from beneath the dunes and aeolian sands from the Nebraska Sand Hills for both mineralogy and geochemistry. Their data suggest little difference in composition between the two except that K-feldspar is less abundant in the Nebraska Sand Hills than in the underlying fluvial sands. Muhs et al. (1997a) speculated on several possible sources for the Nebraska Sand Hills, but did not attempt to identify the most likely source based on mineralogy and geochemistry. These investigators noted, however, that $\mathrm{K}_{2} \mathrm{O}$ concentrations in the Nebraska Sand Hills, as a proxy for K-feldspar, are lower than concentrations of $\mathrm{K}_{2} \mathrm{O}$ in the most commonly hypothesized source sediments, indicating some degree of mineralogical maturity (cf. Fig. 4b).

In North America, including both the Basin and Range and Great Plains, modern river valleys are important as sources for many dune fields based on data presented here and elsewhere (e.g., the Parker dunes, the Yuma Desert dunes, the Gran Desierto, and the Great Bend dunes). Interestingly, the North Platte, South Platte, and Platte Rivers do not seem to have been considered as particularly important sources for the Nebraska Sand Hills by most investigators who have studied them. Yet, winds strong enough to entrain sand-sized particles are dominantly from the south or southeast in summer in Nebraska (see Muhs et al., 1997a; their Fig. 11), which would permit derivation of at least some of the Nebraska Sand Hills sediments from these fluvial sources.

In the present study however, $\mathrm{K} / \mathrm{Rb}$ and $\mathrm{K} / \mathrm{Ba}$ values show that sediments of the Nebraska Sand Hills have only very slight overlap with the compositional field defined by North Platte River sands and virtually no overlap with that defined by the South Platte River
(Fig. 29b). Assuming that Platte River sands would have a composition that is intermediate between that of its two main tributaries, this also effectively eliminates the Platte River as a primary source for the Nebraska Sand Hills. Fluvial inputs to the Nebraska Sand Hills are a possible secondary contributing source, however, as discussed below.

The Pliocene sands found beneath the Nebraska Sand Hills (Fig. 27; see also Figs. 3-4 and 3-5 of Swinehart and Diffendal [1990]) are largely unconsolidated and therefore must be considered as a possible source for the dunes. These sediments, where they have been sampled at six localities in the present study, show a rather narrow range of $\mathrm{K} / \mathrm{Rb}$ and $\mathrm{K} / \mathrm{Ba}$ variability (Fig. 29a). There is some overlap of the Nebraska Sand Hills with the field defined by the Pliocene sediments, but most values do not fall into this field. There is somewhat better overlap between the Nebraska Sand Hills and the field defined by the Tertiary Arikaree Formation (Fig. 29d). The geographic position of the Arikaree Formation is consistent with modern winds and paleowinds from the northwest (Fig. 28). In many places, the Arikaree Formation is a very well-cemented sandstone, and in fact forms the scenic (and resistant) Pine Ridge of northern Nebraska and southern South Dakota (Fig. 28). Nevertheless, at other localities the upper part of the sandstone facies is not well consolidated (for example, see observations in Greene et al., [1991]) and could certainly have been a contributor to the Sand Hills, which is consistent with its $\mathrm{K} / \mathrm{Rb}$ and $\mathrm{K} / \mathrm{Ba}$ compositions.

The best agreement of the $K / \mathrm{Rb}$ and $\mathrm{K} / \mathrm{Ba}$ composition of the Nebraska Sand Hills is with sediments of the Ogallala Formation of Nebraska, South Dakota, and western Wyoming (Fig. 29d). Even with this potential source, however, the overlap of Nebraska Sand Hills samples with the range of Ogallala Formation sands is not perfect, but it is better than for all other source sediments considered. The Ogallala Formation does crop out to the northwest of the Nebraska Sand Hills (Fig. 28), which is consistent with the paleowind reconstructions of the dune field, both for the youngest (Holocene) dunes and also the much larger and older barchanoid ridges (Fig. 27). Although the spatial extent of the Ogallala Formation to the northwest of the Nebraska Sand Hills is limited (and only part of it is shown in Fig. 28), it is generally agreed that the formation was previously more extensive and was stripped by erosion during the late Tertiary or early Pleistocene. This early erosion of the Ogallala Formation could, therefore, have provided much of the initial sediment that forms the present Nebraska Sand Hills. If so, then the mineralogical maturity of the Nebraska Sand Hills is easier to explain because sands of the dune field may have been reworked over many or even all of the glacial-interglacial cycles of the Quaternary, with K-feldspar depletion occurring whenever strong winds prevailed.

Many (though not all) of the Nebraska Sand Hills samples that fall above the compositional field defined by the Ogallala Formation have relatively high $\mathrm{K} / \mathrm{Rb}$ and are found in the south-central part of the dune field. The candidate source sediment with the highest range of $\mathrm{K} / \mathrm{Rb}$ values is sand from the North Platte River, which is closest to the south-central part of the Nebraska Sand Hills. These observations suggest the possibility that there could have been some inputs from the North Platte River, perhaps during summer, with southwesterly winds, at some point or points in the Quaternary history of the Nebraska Sand Hills. Sridhar et al. (2006) and Schmeisser et al. (2010) proposed that during the Medieval Warm Period ( 1000 to $\sim 800 \mathrm{yr}$ B.P.) of the late Holocene, there was a seasonal shift in wind regime over the Nebraska Sand Hills, with northwesterly winds dominant during fall, winter and early spring and southwesterly winds (associated with very warm, dry air masses, bringing drought) in late spring and summer. This seasonal shift in wind regime is invoked to explain the northwest-tosoutheast orientation of linear dunes (found in the southeastern 
part of the Nebraska Sand Hills) with bimodal dip directions. These dunes date to the Medieval Warm Period. Thus, the studies of Sridhar et al. (2006) and Schmeisser et al. (2010) present an intriguing hypothesis to explain the higher $\mathrm{K} / \mathrm{Rb}$ values reported here in the south-central part of the Nebraska Sand Hills.

Swinehart (1990) mapped the landforms of the south-central part of the Nebraska Sand Hills, where higher $\mathrm{K} / \mathrm{Rb}$ values are found, as primarily dome-like dunes, with barchans a bit farther to the west and ultimately barchanoid ridges still farther to the west and north. Examination of aerial photographs in this region shows that many of the dome-like dunes are likely degraded barchans, and these dunes and the better-expressed barchans (both presumably of Pleistocene age) have parabolic dunes (presumably of Holocene age) superimposed on them. In addition, however, some of the parabolic dunes appear to have formed from preexisting linear dunes, although this requires further study. A worthwhile effort would be to map these dunes in detail, study their geomorphology and internal stratigraphy, and conduct mineralogical and geochemical studies for provenance interpretations.

The evidence of possible inputs of North Platte River sands (with their relatively higher $\mathrm{K}$ concentrations) from southwesterly winds during the late Holocene may also explain what has been an enigmatic spatial pattern of $\mathrm{K}$ concentrations in the south-central Nebraska Sand Hills, based on airborne gamma-ray surveys (shown as Fig. 9 in Muhs et al., [1997a]). Compared to the rest of the Nebraska Sand Hills, the south-central part of the dune field has higher concentrations of $\mathrm{K}$ based on both gamma surveys and laboratory-based measurements. The higher concentrations of $\mathrm{K}$ and the higher $\mathrm{K} / \mathrm{Rb}$ values in sands from this area can both be explained by inputs of North Platte River sands to the Nebraska Sand Hills from southwesterly winds during the late Holocene. This hypothesis requires much more testing, but it could be done effectively with the combined geomorphic, sedimentologic, mineralogic, and geochemical study described above.

\section{Conclusions}

Quaternary dune fields occupy large areas of the world's arid and semiarid regions, but there has been comparatively little work done on understanding dune sediment provenance. Nevertheless, identification of aeolian sand sources is critical for determining the aeolian system sediment state of a dune field, including the potential for reactivation of stable dune fields or expansion of existing ones. The mineralogy of a dune field may evolve over time, even on a Quaternary timescale, due either to loss of unstable minerals by chemical weathering during periods of stability or mineral loss by ballistic impacts and abrasion during periods of activity. Thus, methods for determining dune sand provenance must be immune to mineralogical evolution over time. Aeolian geomorphologists need a method for rapid and inexpensive but reliable determination of possible dune sand sources.

Most dune fields contain at least some K-feldspar, a common rock-forming mineral. Two trace elements that follow $\mathrm{K}, \mathrm{Rb}$ and $\mathrm{Ba}$, are found in $\mathrm{K}$-feldspars, and thus $\mathrm{K} / \mathrm{Rb}$ and $\mathrm{K} / \mathrm{Ba}$ values are a measure of K-feldspar composition. An exploration and evaluation of the potential for using $\mathrm{K} / \mathrm{Rb}$ and $\mathrm{K} / \mathrm{Ba}$ as provenance indicators for aeolian sand are presented here. Examples are taken from previously studied Quaternary dune fields in the arid portions of the Basin and Range and semiarid portions of the Great Plains regions of North America.

Different river sands that are potential dune sand sources can be easily distinguished using $\mathrm{K} / \mathrm{Rb}$ and $\mathrm{K} / \mathrm{Ba}$. In the Great Plains region, the Souris, North Platte, South Platte, and Pecos Rivers all have distinctive compositions with little or no overlap, reflecting the different source rocks found in their drainage areas. Similarly, different dune fields in the deserts of the Basin and Range and Great Plains have distinctive $\mathrm{K} / \mathrm{Rb}$ and $\mathrm{K} / \mathrm{Ba}$ compositions. These simple comparisons show that the method has potential as a provenance indicator.

Over the past century, there have been some studies of dune field origins in the Basin and Range and Great Plains regions of North America. These modes of origin are newly assessed using K/ $\mathrm{Rb}$ and $\mathrm{K} / \mathrm{Ba}$ values in the dune sands and hypothesized source sediments. Many of the dune field source sediments identified in previous studies are supported with the new $\mathrm{K} / \mathrm{Rb}$ and $\mathrm{K} / \mathrm{Ba}$ data presented here. In the Basin and Range province, this includes the Algodones Dunes of California, previously interpreted to be derived from Lake Cahuilla shoreline sediments that are in turn derived from the Colorado River, and the Yuma Desert dunes of Arizona, derived directly from the Colorado River. In the Great Plains region, $\mathrm{K} / \mathrm{Rb}$ and $\mathrm{K} / \mathrm{Ba}$ values indicate that the Muleshoe dunes of New Mexico and Texas are derived dominantly from the Blackwater Draw Formation. In the Great Bend area of Kansas, K/Rb and K/Ba values in dunes are consistent with derivation from the Arkansas River.

In other areas, $\mathrm{K} / \mathrm{Rb}$ and $\mathrm{K} / \mathrm{Ba}$ data suggest different sources or greater complexity for dune field origins than previously thought. Examples of this include the Parker dunes of Arizona, which appear to have a larger component of local alluvium from Bouse Wash, as well as partial derivation from the Colorado River. In New Mexico and Texas, the Lea-Yoakum dunes could be derived from both the Blackwater Draw Formation and alluvium from the Pecos River. Previously thought to be derived primarily from the South Platte River, the Wray dunes of northeastern Colorado may have had influences from the Tertiary Ogallala Formation, and this may also explain part of the composition of the nearby Imperial dunes of southwestern Nebraska. The Greeley dunes of northeastern Colorado are likely derived primarily from bedrock sources such as the Cretaceous Laramie Formation but also possibly the Ogallala Formation, despite the proximity of these dunes to the South Platte River. The Lincoln County dunes of southwestern Nebraska are likely derived from a mix of aeolian sand from the Nebraska Sand Hills (which may have been more extensive in the last glacial period) and South Platte River sands. Dunes of the Nebraska Sand Hills have a source or sources that are still somewhat elusive, but the Tertiary Ogallala Formation, long favored by early researchers, is a good candidate for further research. Nevertheless, there is evidence that the North Platte River may have provided some sand to at least parts of the Nebraska Sand Hills as well.

$\mathrm{K} / \mathrm{Rb}$ and $\mathrm{K} / \mathrm{Ba}$ analyses of dune sands are inexpensive, rapid, accurate, and highly reproducible. The method utilizes one of the most common minerals found in dune sand, K-feldspar. With the exception of very mature dune fields that are composed exclusively of quartz, the $\mathrm{K} / \mathrm{Rb}$ and $\mathrm{K} / \mathrm{Ba}$ geochemical method can be applied to aeolian sands from highly diverse terrains. The method avoids the problem of using simple concentrations of key elements that may be subject to interpretative bias due to changes in mineralogical maturity of dune fields that occur over time. As pointed out by Muhs et al. (2017), many dune fields in other parts of the world could benefit from $\mathrm{K} / \mathrm{Rb}$ and $\mathrm{K} / \mathrm{Ba}$ analyses for identification of sand sources, including those in southern Africa, North Africa, the Middle East, Asia, and South America. Where geochemical methods using $\mathrm{K} / \mathrm{Rb}$ and $\mathrm{K} / \mathrm{Ba}$ do not yield a conclusive identification of dune source sediments, it is recommended that a fruitful approach is a combined examination of $\mathrm{Pb}$-isotopic compositions in K-feldspars and $\mathrm{U}-\mathrm{Pb}$ age distributions of detrital zircons, following the approach of Aleinikoff et al. (1999, 2008) for loess in Colorado and Nebraska and Alizai et al. (2011) and East et al. (2015) for the origin of dunes in the Thar Desert of India. 


\section{Acknowledgments}

This study was supported by the Climate and Land Use Change Research and Development Program of the U.S. Geological Survey. Gary Skipp conducted the X-ray diffraction analyses, for which I am grateful. I thank Shannon Mahan and Brian Marshall for assistance in acquiring the geochemical data, collected over many years, presented here. Heartfelt thanks go to the many aeolian geomorphologists that I have looked at dunes with over the years in the USA, Canada, Mexico, Egypt, Israel, and Tunisia, including John Aleinikoff, Al Arbogast, Alan Busacca, Chuck Bush, Nabil Gasmi, Vance Holliday, Nick Lancaster, Dave Loope, Rich Madole, Naomi Porat, Margaret Hiza Redsteer, Joel Roskin, Zachary Muhs Rowland, Chris Schenk, Jim Swinehart, Haim Tsoar, Steve Wolfe, and the late Dan Yaalon. Chris Schenk (U.S. Geological Survey) kindly provided splits of dune sand samples collected by the late Ed McKee (U.S. Geological Survey) in Libya, Namibia, and Australia and Amihai Sneh (Geological Survey of Israel, retired) kindly supplied the samples from the Sinai Desert of Egypt. Xiaoping Yang (QSR Editor) Amy East and Janet Slate (both U.S. Geological Survey) and an anonymous reviewer read an earlier version of this paper and offered very useful suggestions, which I appreciate. Joe Mason (University of Wisconsin) read the paper in detail and made many helpful comments for which I am grateful. Joe also kindly provided a file of his detailed aeolian landforms map of southwestern Nebraska. All use of trade names is for descriptive purposes only and does not imply endorsement by the U.S. government.

\section{Supplementary data}

Supplementary data related to this article can be found at http:// dx.doi.org/10.1016/j.quascirev.2017.07.007.

\section{References}

Ahlbrandt, T.S., Swinehart, J.B., Maroney, D.G., 1983. The dynamic Holocene dune fields of the Great Plains and Rocky Mountain basins, U.S.A. In: Brookfield, M.E. Ahlbrandt, T.S. (Eds.), Eolian Sediments and Processes. Elsevier, New York, pp. $379-406$

Aleinikoff, J.N., Muhs, D.R., Sauer, R., Fanning, C.M., 1999. Late Quaternary loess in northeastern Colorado, Part II - Pb isotopic evidence for the variability of loess sources. Geol. Soc. Am. Bull. 111, 1876-1883.

Aleinikoff, J.N., Muhs, D.R., Bettis III, E.A., Johnson, W.C., Fanning, C.M., Benton, R 2008. Isotopic evidence for the diversity of late Quaternary loess in Nebraska: Glaciogenic and non-glaciogenic sources. Geol. Soc. Am. Bull. 120, 1362-1377.

Alizai, A., Clift, P.D., Giosan, L., VanLaningham, S., Hinton, R., Tabrez, A.R., Danish, M. EIMF, 2011. Pb isotopic variability in the modern-Pleistocene Indus river system measured by ion microprobe in detrital K-feldspar grains. Geochim. Cosmochim. Acta 75, 4771-4795.

Arbogast, A.F., 1996. Stratigraphic evidence for late-Holocene eolian sand mobilization and soil formation in south-central Kansas. U.S.A. J. Arid Environ. 34 403-414.

Arbogast, A.F., 1998. Late-Quaternary climate change and landscape evolution on the Great Bend Sand Prairie. Kans. Geol. Surv. Bull. 242, 1-74.

Arbogast, A.F., Johnson, W.C., 1998. Late-Quaternary landscape response to environmental change in south-central Kansas. Ann. Assoc. Am. Geogr. 88, 125-146.

Arbogast, A.F. Muhs, D.R., 2000. Geochemical and mineralogical evidence from eolian sediments for northwesterly mid-Holocene paleowinds, central Kansas, U.S.A. Quat. Int. 67, 107-118.

Bettis III, E.A., Mason, J.P., Swinehart, J.B., Miao, X., Hanson, P.R., Goble, R.J., Loope, D.B., Jacobs, P.M., Roberts, H.M., 2003. Cenozoic eolian sedimentary systems of the USA midcontinent. In: Easterbrook, D. (Ed.), Quaternary Geology of the United States, INQUA 2003 Field Guide Volume. Desert Research Institute Reno, NV, pp. 195-218.

Birkeland, P.W., 1999. Soils and Geomorphology. Oxford University Press, New York, 430 pp.

Bishop, C.C., 1963. Geologic Map of California-Needles Sheet. California Division of Mines and Geology, scale 1:250,000.

Blake, W.P., 1857. Geological Report. In: Reports of Explorations and Surveys to Ascertain the Most Practicable and Economical Route for a Railroad from the Mississippi River to the Pacific Ocean. 33rd Congress, 2nd Session, Senate Executive Document No. 78, 370 pp.

Blount, G., Lancaster, N., 1990. Development of the Gran Desierto sand sea, northwestern Mexico. Geology 18, 724-728.
Breed, C.S., 1999. Monitoring Surface Changes in Desert Areas. U.S. Geological Survey Professional Paper 1598-A, pp. 1-27.

Brown, J.S., 1923. The Salton Sea Region, California. U.S. Geological Survey WaterSupply Paper 497.

Burchett, R.R., 1986. Geologic Bedrock Map of Nebraska. Nebraska Geological Survey GMC-1, scale $1: 1,000,000$.

Carlisle, W.J., Marrs, R.W., 1982. Eolian features of the Southern High Plains and their relationship to windflow patterns. Geol. Soc. Am. Special Pap. 192, 89-105.

Clarke, M.L., Rendell, H.M., 1998. Climate change impacts on sand supply and the formation of desert sand dunes in the south-west U.S.A. J. Arid Environ. 39, $517-531$.

Clarke, M.L., Richardson, C.A., Rendell, H.M., 1996. Luminescence dating of Mojave desert sands. Quat. Sci. Rev. 14, 783-790.

Collerson, K.D., 1975. Contrasted patterns of K/Rb distribution in Precambrian high grade metamorphic rocks from central Australia. J. Geol. Soc. Aust. 22, 145-158.

Cooke, R., Warren, A., Goudie, A., 1993. Desert Geomorphology. UCL Press Limited, London, $526 \mathrm{pp}$

Cornwall, C., Bandfield, J.L., Titus, T.N., Schreiber, B.C., Montgomery, D.R., 2015. Physical abrasion of mafic minerals and basalt grains: Application to martian aeolian deposits. Icarus 256, 13-21.

Crouvi, O., Amit, R., Porat, N., Gillespie, A.R., McDonald, E.V., Enzel, Y., 2009. Significance of primary hilltop loess in reconstructing dust chronology, accretion rates, and sources: an example from the Negev Desert, Israel. J. Geophys. Res. 114, F02017. http://dx.doi.org/10.1029/2008JF001083.

Dane, C.H., Bachman, G.O., 1965. Geologic Map of New Mexico. U.S. Geological Survey map, scale 1:500,000.

Diffendal Jr., R.F., Leite, M.B., 1989. Late Quaternary alluvial and lacustrine fills, Keith and Garden Counties, Nebraska-The conundrum reconsidered: TER-QUA 1989 Abstracts. Colorado State University.

Dohrenwend, J.C., Smith, R.S.U., 1991. Quaternary geology and tectonics of the Salton Trough. In: Morrison, R.B. (Ed.), Quaternary Nonglacial Geology: Conterminous U.S. Geological Society of America, Boulder, Colorado, the Geology of North America, K-2, pp. 334-337.

Dott Jr., R.H., 2003. The importance of eolian abrasion in supermature quartz sandstones and the paradox of weathering on vegetation-free landscapes. J. Geol. 111, 387-405.

Dutta, P.K., Zhou, Z., dos Santos, P.R., 1993. A theoretical study of mineralogical maturation of eolian sand. Geol. Soc. Am. Special Pap. 284, 203-209.

East, A.E., Clift, P.D., Carter, A., Alizai, A., VanLaningham, S., 2015. Fluvial-eolian interactions in sediment routing and sedimentary signal buffering: an example from the Indus Basin and Thar Desert. J. Sediment. Res, 85, 715-728.

Enzel, Y., Amit, R., Crouvi, O., Porat, N., 2010. Abrasion-derived sediments under intensified winds at the latest Pleistocene leading edge of the advancing SinaiNegev erg. Quat. Res. 74, 121-131.

Forman, S.L., Marín, L., Pierson, J., Gómez, J., Miller, G.H., Webb, R.S., 2005. Aeolian sand depositional records from western Nebraska: landscape response to droughts in the past 1500 years. Holocene 15, 973-981.

Fryberger, S.G., Dean, G., 1979. Dune forms and wind regime. In: McKee, E.D. (Ed.) A Study of Global Sand Seas. U.S. Geological Survey Professional Paper 1052, pp. 137-169.

Gardner, R.A.M., Pye, K., 1981. Nature, origin and palaeoenvironmental significance of red coastal and desert dune sands. Prog. Phys. Geogr. 5, 514-534.

Garzanti, E., Andò, S., Vezzoli, G., Lustrino, M., Boni, M., Vermeesch, P., 2012. Petrology of the Namib sand sea: Long-distance transport and compositional variability in the wind-displaced Orange Delta. Earth Sci. Rev. 112, 173-189.

Garzanti, E., Vermeesch, P., Andò, S., Vezzoli, G., Valagussa, M., Allen, K., Kadi, K.A., Al-Juboury, A.I.A., 2013. Provenance and recycling of Arabian desert sand. Earth Sci. Rev, 120,1-19.

Gilbert, G.K., 1896. The Underground Water of the Arkansas Valley in Eastern Colorado. U.S. Geological Survey $17^{\text {th }}$ Annual Report, part 2, pp. 557-601.

Goldschmidt, V.M., 1954. Geochemistry. Clarendon Press, Oxford, 730 pp.

Goble, R.J., Mason, J.A., Loope, D.B., Swinehart, J.B., 2004. Optical and radiocarbon ages of stacked paleosols and dune sands in the Nebraska Sand Hills, USA. Quat. Sci. Rev. 23, 1173-1182.

Goudie, A.S., 2002. Great Warm Deserts of the World: Landscapes and Evolution. Oxford University Press, Oxford, 480 pp.

Goudie, A.S., Stokes, S., Livingstone, I., Bailiff, I.K., Allison, R.J., 1993. Post-depositional modification of the linear sand ridges of the West Kimberley area of north-west Australia. Geogr. J. 159, 306-317.

Govindaraju, K., 1989. 1989 compilation of working values and sample description for 272 geostandards. Geostand. Newsl. 13, 1-113.

Green, F.E., 1961. The Monahans dunes area. In: Wendorf, F., compiler (Eds.), Paleoecology of the Llano Estacado. Fort Burgwin Research Center Publication 1. Museum of New Mexico Press, Santa Fe, pp. 22-47.

Greene, E.A., Anderson, M.T., Sipe, D.D., 1991. Aquifer Tests and Water-quality Analyses of the Arikaree Formation Near Pine Ridge, South Dakota. U.S. Geological Survey Water-Resources Investigations Report 91-4005, 45 pp.

Gunn, B.M., 1965. K/Rb and K/Ba ratios in Antarctic and New Zealand tholeiites and alkali basalts. J. Geophys. Res. 70, 6241-6247.

Gustavson, T.C., Holliday, V.T., 1999. Eolian sedimentation and soil development on a semiarid to subhumid grassland, Tertiary Ogallala and Quaternary Blackwater Draw formations, Texas and New Mexico high plains. J. Sediment. Res. 69, 622-634.

Hack, J.T., 1941. Dunes of the western Navajo country. Geogr. Rev. 31, 240-263.

Halfen, A.F., Lancaster, N., Wolfe, S., 2016. Interpretations and common challenges of 
aeolian records from North American dune fields. Quat. Int. 410 (B), 75-95.

Halfen, A.F., Johnson, W.C., Hanson, P.R., Woodburn, T.L., Young, A.R. Ludvigson, G.A., 2012. Activation history of the Hutchinson dunes in eastcentral Kansas, USA during the past 2200 years. Aeolian Res. 5, 9-20.

Hall, S.A., Goble, R.J., 2006. Geomorphology, stratigraphy, and luminescence age of the Mescalero sands, southeastern New Mexico. New Mexico Geological Society Guidebook, 57th Field Conference, Caves and Karst of Southeastern New Mexico, pp. 297-310.

Hall, S.A., Goble, R.J., 2015. OSL age and stratigraphy of the Strauss sand sheet in New Mexico, USA. Geomorphology 241, 42-54.

Hartman, B.M., Scranton, D.F., 1992. Geologic Map of Texas. University of Texas at Austin, Bureau of Economic Geology map, scale of individual sheets, 1:250,000.

Hawley, J.W., Bachman, G.O., Manley, K., 1976. Quaternary stratigraphy in the Basin and Range and Great Basin provinces, New Mexico and western Texas. In: Mahaney, W.C. (Ed.), Quaternary Stratigraphy of North America: Stroudsburg, Pennsylvania, Dowden, Hutchinson and Ross, Inc, pp. 235-274.

Hefley, H.M., Sidwell, R., 1945. Geological and ecological observations of some High Plains dunes. Am. J. Sci. 243, 361-376.

Heier, K.S., Adams, J.A.S., 1964. The geochemistry of the alkali metals. Phys. Chem. Earth 5, 253-381.

Helm, P.J., Breed, C.S., 1999. Instrumented Field Studies of Sediment Transport by Wind. U.S. Geological Professional Paper 1598-B, pp. 29-51.

Hole, M.J., Kempton, P.D., Millar, I.L., 1993. Trace-element and isotopic characteristics of small-degree melts of the asthenosphere: Evidence from the alkalic basalts of the Antarctic Peninsula. Chem. Geol. 109, 51-68.

Holliday, V.T., 1989. The Blackwater Draw Formation (Quaternary): A 1.4-plus m.y. record of eolian sedimentation and soil formation on the Southern High Plains. Geol. Soc. Am. Bull. 101, 1598-1607.

Holliday, V.T., 1990. Soils and landscape evolution of eolian plains: the Southern High Plains of Texas and New Mexico. Geomorphology 3, 489-515.

Holliday, V.T., 2001. Stratigraphy and geochronology of upper Quaternary eolian sand on the Southern High Plains of Texas and New Mexico, United States. Geol. Soc. Am. Bull. 113, 88-108.

Hunt, C.B., 1977. Surficial Geology of Southeast New Mexico. New Mexico Bureau of Mines and Mineral Resources Geologic Map 41, scale 1: 500,000.

Hunt, C.B., 1986. Surficial Deposits of the United States. Van Nostrand Reinhold Company, New York, 189 pp.

Jennings, C.W., 1967. Geologic Map of California Salton Sea Sheet. California Division of Mines and Geology, Sacramento, California scale 1:250,000.

Joeckel, R.M., Wooden Jr., S.R., Korus, J.T., Garbisch, J.O., 2014. Architecture, heterogeneity, and origin of late Miocene fluvial deposits hosting the most important aquifer in the Great Plains, USA. Sediment. Geol. 311, 75-95.

Johnson, R.G., King, B.S.L., 1987. Energy-dispersive X-ray fluorescence spectrometry. U.S. Geol. Surv. Bull. 1770, F1-F5.

Kasper-Zubillaga, J.J., Zolezzi-Ruíz, H., Carranza-Edwards, A., Girón-García, P., OrtizZamora, G., Palma, M., 2007. Sedimentological, modal analysis and geochemical studies of desert and coastal dune sands, Altar Desert, NW Mexico. Earth Surf. Process. Landforms 32, 489-508.

Kocurek, G., Lancaster, N., 1999. Aeolian system sediment state: theory and Mojave Desert Kelso dune field example. Sedimentology 46, 505-515.

Kuenen, Ph.H., 1960. Experimental abrasion 4: Eolian action. J. Geol. 68, 427-449.

Kuzila, M.S., Mack, A.M., Culver, J.R., Schaefer, S.J., 1990. General Soil Map of Nebraska. Conservation and Survey Division, Institute of Agriculture and Natural Resources, University of Nebraska, Lincoln and U.S. Department of Agriculture Soil Conservation Service.

Lancaster, N., 1989. The Namib Sand Sea: Dune Forms, Processes and Sediments. A.A. Balkema, Rotterdam, 200 pp.

Lancaster, N., 1994. Controls on aeolian activity: some new perspectives from the Kelso Dunes, Mojave Desert, California. J. Arid Environ. 27, 113-125.

Lancaster, N., 1995a. Geomorphology of Desert Dunes. Routledge, London, 290 pp.

Lancaster, N., 1995b. Origin of the Gran Desierto sand sea: Sonora, Mexico: Evidence from dune morphology and sediments. In: Tchakerian, V.P. (Ed.), Desert Aeolian Processes. Chapman \& Hall, New York, pp. 11-36.

Lancaster, N., Tchakerian, V.P., 1996. Geomorphology and sediments of sand ramps in the Mojave Desert. Geomorphology 17, 151-165.

Lancaster, N., Tchakerian, V.P., 2003. Late Quaternary eolian dynamics, Mojave Desert, California. Geol. Soc. Am. Special Pap. 368, 231-249.

Lancaster, N., Greeley, R., Christensen, P.R., 1987. Dunes of the Gran Desierto sandsea, Sonora, Mexico, Earth Surf. Process. Landforms 12, 277-288.

Lange, I.M., Reynolds, R.C., Lyons, J.B., 1966. K/Rb ratios in coexisting K-feldspars and biotites from some New England granites and metasediments. Chem. Geol. 1, 317-322.

Livingstone, I., Warren, A., 1996. Aeolian Geomorphology: An Introduction. Longman, London, 211 pp.

Loeltz, O.J., Irelan, B., Robison, J.H., Olmsted, F.H., 1975. Geohydrologic Reconnaissance of the Imperial Valley, California. U.S. Geological Survey Professional Paper 486-K.

Loope, D.B., Swinehart, J.B., 2000. Thinking like a dune field: Geologic history in the Nebraska Sand Hills. Gt. Plains. Res. 10, 5-35.

Loope, D.B., Swinehart, J.B., Mason, J.P., 1995. Dune-dammed paleovalleys of the Nebraska Sand Hills: Intrinsic versus climatic controls on the accumulation of lake and marsh sediments. Geol. Soc. Am. Bull. 107, 396-406.

Lorenz, R.D., Zimbelman, J.R., 2014. Dune Worlds: How Windblown Sand Shapes Planetary Landscapes. Springer, 308 pp.

Love, J.D., Christiansen, A.C., 1985. Geologic Map of Wyoming. U.S. Geological
Survey map, scale 1:500,000

Lugn, A.L., 1935. The Pleistocene Geology of Nebraska. Nebraska Geological Survey Bulletin 10 (2nd series), 223 pp.

Lugn, A.L., 1962. The Origin and Sources of Loess in the Central Great Plains and Adjoining Areas of the Central Lowland. Nebraska University Studies. New Series 26, part XI, 105 pp.

Lugn, A.L., 1968. The origin of loesses and their relation to the Great Plains in North America. In: Schultz, C.B., Frye, J.C. (Eds.), Loess and Related Eolian Deposits of the World. University of Nebraska Press, Lincoln, pp. 139-182.

Madole, R.F., 1995. Spatial and temporal patterns of late Quaternary eolian deposition, eastern Colorado. U.S.A. Quat. Sci. Rev. 14, 155-177.

Madole, R.F., VanSistine, D.P., Michael, J.A., 2005. Distribution of Late Quaternary Wind-deposited Sand in Eastern Colorado. U.S. Geological Survey Scientific Investigations Map 2875, scale 1:700, 000, 49 p.

Marsland, P.S., Woodruff, J.G., 1937. A study of the effects of wind transportation on grains of several minerals. J. Sediment. Petrol. 7, 18-30.

Martin, J.E., Sawyer, J.F., Fahrenbach, M.D., Tomhave, D.W., Schulz, L.D., 2004 Geologic Map of South Dakota. South Dakota Department of Environment and Natural Resources, Geological Survey General Map 10, scale 1:500,000.

Mason, B., Moore, C.B., 1982. Principles of Geochemistry. Wiley, New York, 344 pp.

Mason, J.A., Swinehart, J.B., Goble, R.J., Loope, D.B., 2004. Late-Holocene dune activity linked to hydrological drought, Nebraska Sand Hills, USA. Holocene 14, 209-217.

Mason, J.A., Swinehart, J.B., Hanson, P.R., Loope, D.B., Goble, R.J., Miao, X., Schmeisser, R.L., 2011. Late Pleistocene dune activity in the central Great Plains, USA. Quat. Sci. Rev. 30, 3858-3870.

May, D.W., Swinehart, J.B., Loope, D., Souders, V., 1995. Late Quaternary fluvial and eolian sediments: Loup river Basin and the Nebraska Sand Hills. In: Diffendal Jr., R.F., Flowerday, C.A. (Eds.), Geologic Field Trips in Nebraska and Adjacent Parts of Kansas and South Dakota: Conservation and Survey Division, Institute of Agriculture and Natural Resources. University of Nebraska-Lincoln, Guidebook No. 10, pp. 13-31.

McCoy Jr., F.W., Nokleberg, W.J., Norris, R.M., 1967. Speculations on the origin of the Algodones dunes, California. Geol. Soc. Am. Bull. 78, 1039-1044.

McKee, E.D., 1979. Ancient sandstones considered to be eolian. In: McKee, E.D. (Ed.), A Study of Global Sand Seas. U.S. Geological Survey Professional Paper 1052, pp. 187-233.

McKee, E.D., 1982. Sedimentary Structures in Dunes of the Namib Desert, South West Africa. Geological Society of America Special Paper 188, pp. 1-64.

McKee, E.D., Tibbitts Jr., G.C., 1964. Primary structures of a seif dune and associated deposits in Libya. J. Sediment. Petrol. 34, 5-17.

McCuaig, T.C., Kerrich, R., 1998. P-T-t-deformation-fluid characteristics of lode gold deposits: evidence from alteration systematics. Ore Geol. Rev. 12, 381-453.

Merriam, R., 1969. Source of sand dunes of southeastern California and northwestern Sonora, Mexico. Geol. Soc. Am. Bull. 80, 531-534.

Metzger, D.G., Loeltz, O.J., Irelna, B., 1973. Geohydrology of the Parker-Blythe-Cibola Area, Arizona and Californa. U.S. Geological Survey Professional Paper 486-C, 130 pp.

Miao, X.D., Mason, J.A., Swinehart, J.B., Loope, D.B., Hanson, P.R., Goble, R.J., Liu, X.D., 2007. A 10,000 year record of dune activity, dust storms, and severe drought in the central Great Plains. Geology 35, 119-122.

Morrison, R.B., 1969. Photointerpretive mapping from space photographs of Quaternary geomorphic features and soil associations in northern Chihuahua and adjoining New Mexico and Texas. In: Cordoba, D.A., Wengerd, S.A., Shomaker, J. (Eds.), Guidebook of the Border Region. New Mexico Geological Society, Twentieth Field Conference, pp. 116-129.

Moufti, A.M.B., 2013. Mineralogy, geochemistry and possible provenance of desert sand dunes from western Rub' al Khali area, southeastern Saudi Arabia. Int. J. Basic Appl. Sci. 2, 399-407.

Muhs, D.R., 1985. Age and paleoclimatic significance of Holocene sand dunes in northeastern Colorado. Ann. Assoc. Am. Geogr. 75, 566-582.

Muhs, D.R., 2004. Mineralogical maturity in dune fields of North America, Africa and Australia. Geomorphology 59, 247-269.

Muhs, D.R., Holliday, V.T., 1995. Evidence for active dune sand on the Great Plains in the 19th century from accounts of early explorers. Quat. Res. 43, 198-208.

Muhs, D.R., Holliday, V.T., 2001. Origin of late Quaternary dune fields on the Southern High Plains of Texas and New Mexico. Geol. Soc. Am. Bull. 113, 75-87.

Muhs, D.R., Zárate, M., 2001. Eolian records of the Americas and their paleoclimatic significance. In: Markgraf, V. (Ed.), Interhemispheric Climate Linkages. Academic Press, San Diego, pp. 183-216.

Muhs, D.R., Bush, C.A., Cowherd, S.D., Mahan, S., 1995. Geomorphic and geochemical evidence for the source of sand in the Algodones dunes, Colorado Desert, southeastern California. In: Tchakerian, V.P. (Ed.), Desert Aeolian Processes. Chapman and Hall, London, pp. 37-74.

Muhs, D.R., Stafford, T.W., Cowherd, S.D., Mahan, S.A., Kihl, R., Maat, P.B., Bush, C.A. Nehring, J., 1996. Origin of the late Quaternary dune fields of northeastern Colorado. Geomorphology 17, 129-149.

Muhs, D.R., Stafford Jr., T.W., Swinehart, J.B., Cowherd, S.D., Mahan, S.A., Bush, C.A., 1997a. Late Holocene eolian activity in the mineralogically mature Nebraska Sand Hills. Quat. Res. 48, 162-176.

Muhs, D.R., Stafford Jr., T.W., Been, J., Mahan, S.A., Burdett, J., Skipp, G., Rowland, Z.M., 1997b. Holocene eolian activity in the Minot dune field, North Dakota. Can. J. Earth Sci. 34, 1442-1459.

Muhs, D.R., Swinehart, J.B., Loope, D.B., Aleinikoff, J.N., Been, J., 1999. 200,000 years of climate change recorded in eolian sediments of the High Plains of eastern 
Colorado and western Nebraska. Geol. Soc. Am. Field Guide 1, 71-91.

Muhs, D.R., Swinehart, J.B., Loope, D.B., Been, J., Mahan, S.A., Bush, C.A., 2000. Geochemical evidence for an eolian sand dam across the North and South Platte rivers in Nebraska. Quat. Res. 53, 214-222.

Muhs, D.R., Reynolds, R., Been, J., Skipp, G., 2003. Eolian sand transport pathways in the southwestern United States: importance of the Colorado River and loca sources. Quat. Int. 104, 3-18.

Muhs, D.R., Bettis III, E.A., Aleinikoff, J., McGeehin, J.P., Beann, J., Skipp, G. Marshall, B.D., Roberts, H.M., Johnson, W.C., Benton, R., 2008. Origin and paleoclimatic significance of late Quaternary loess in Nebraska: Evidence from stratigraphy, chronology, sedimentology, and geochemistry. Geol. Soc. Am. Bull. $120,1378-1407$.

Muhs, D.R., Skipp, G., Schumann, R.R., Johnson, D.L., McGeehin, J.P., Beann, J. Freeman, J., Pearce, T.A., Rowland, Z.M., 2009. The origin and paleoclimatic significance of carbonate sand dunes deposited on the California Channe Islands during the last glacial period. In: Damiani, C.C., Garcelon, D.K. (Eds.), Proceedings of the 7th California Islands Symposium; Arcata, California: Institute for Wildlife Studies, pp. 3-14.

Muhs, D.R., Roskin, J., Tsoar, H., Skipp, G., Budahn, J.R., Sneh, A., Porat, N., Stanley, J.D. Katra, I., Blumberg, D.G. 2013a. Origin of the Sinai-Negev erg, Egypt and Israel: mineralogical and geochemical evidence for the importance of the Nile and sea level history. Quat. Sci. Rev. 69, 28-48.

Muhs, D.R., Bettis III, E.A., Roberts, H.M., Harlan, S., Paces, J.B., Reynolds, R., 2013b. Chronology and provenance of last-glacial (Peoria) loess in western Iowa and paleoclimatic implications. Quat. Res. 80, 468-481.

Muhs, D.R., Lancaster, N., Skipp, G.L., 2017. A complex origin for the Kelso Dunes, Mojave National Preserve, California USA: A case study using a simple geochemical method with global applications. Geomorphology 276, 222-243.

Myers, M., 1993. A Pliocene Eolian Sand Sheet beneath the Nebraska Sand Hills. Unpublished M.S. thesis. University of Nebraska, Lincoln.

Norris, R.M., Norris, K.S., 1961. Algodones dunes of southeastern California. Geol. Soc. Am. Bull. 72, 605-620.

Olmsted, F.H., Loeltz, O.J., Irelan, B., 1973. Geohydrology of the Yuma Area, Arizona and California. U.S. Geological Survey Professional Paper 486-H, 227 pp.

Parker, D.F., Ghosh, A., Price, C.W., Rinard, B.D., Cullers, R.L., Ren, M., 2005. Origin of rhyolite by crustal melting and the nature of parental magmas in the Oligocene Conejos Formation, San Juan Mountains, Colorado, USA. J. Volcanol. Geotherm. Res. 139, 185-210.

Pease, P.P., Tchakerian, V.P., 2002. Composition and sources of sand in the Wahiba Sand Sea, Sultanate of Oman. Ann. Assoc. Am. Geogr. 92, 416-434.

Pettijohn, F.J., Potter, P.E., Siever, R., 1973. Sand and Sandstone. Springer-Verlag, New York, $618 \mathrm{pp}$.

Pilkey, O., 1972. Barium: element and geochemistry. In: Fairbridge, R.W. (Ed.), The Encyclopedia of Geochemistry and Environmental Sciences. Van Nostrand Reinhold Company, New York, pp. 62-63.

Pye, K., Tsoar, H., 1990. Aeolian Sand and Sand Dunes. Unwin Hyman, London, 396 pp.

Reed, E.C., 1968. Loess deposition in Nebraska. In: Schultz, C.B., Frye, J.C. (Eds.), Loess and Related Eolian Deposits of the World. University of Nebraska Press, Lincoln, pp. 139-182.

Reynolds, R.C., 1972. Rubidium: element and geochemistry. In: Fairbridge, R.W. (Ed.), The Encyclopedia of Geochemistry and Environmental Sciences. Van Nostrand Reinhold Company, New York, pp. 1050-1051.

Rich, J., Stokes, S., 2011. A 200,000-year record of late Quaternary aeolian sedimentation on the Southern High Plains and nearby Pecos River valley, USA. Aeolian Res. 2, 221-240.

Roskin, J., Porat, N., Tsoar, H., Blumberg, D.G., Zander, A.M., 2011. Age, origin and climatic controls on vegetated linear dunes in the northwestern Negev Desert (Israel). Quat. Sci. Rev. 30, 1649-1674.

Roskin, J., Blumberg, D.G., Porat, N., Tsoar, H., Rozenstein, O., 2012. Do dune sands redden with age? The case of the northwestern Negev dunefield. Israel. Aeolian Res. 5, 63-75.

Ross, J.A., Wong, M.K., Chyn, H.M., Wong, R.K.W., Kirshen, D.S., Wong, W.K., Collins, D.R., Ross, C.G., Brady, L.R., 1991. Geologic Map of Kansas. Kansas Geological Survey, Map Series 23, scale, 1:500,000.

Scheidt, S., Lancaster, N., Ramsey, M., 2011. Eolian dynamics and sediment mixing in the Gran Desierto, Mexico, determined from thermal infrared spectroscopy and remote-sensing data. Geol. Soc. Am. Bull. 123, 1628-1644.

Schmeisser, R.L., Loope, D.B., Mason, J.A., 2010. Modern and late Holocene wind regimes over the Great Plains (central U.S.A.). Quat. Sci. Rev. 29, 554-566.

Schmeisser McKean, R.L., Goble, R.J., Mason, J.B., Swinehart, J.B., Loope, D.B., 2015 Temporal and spatial variability in dune reactivation across the Nebraska Sand Hills, USA. The Holocene 25, 523-535.

Scott, G.R., 1968. Geologic and Structure Contour Map of the La Junta Quadrangle Colorado and Kansas. U.S. Geological Survey Miscellaneous Investigations Series Map I-560, scale 1:250,000.

Scott, G.R., 1978. Map Showing Geology, Structure, and Oil and Gas Fields in the Sterling $1^{\circ}$ X $2^{\circ}$ Quadrangle, Colorado, Nebraska, and Kansas. U.S. Geologica Survey Miscellaneous Investigations Series Map 1092, scale 1:250,000.

Sharps, J.A., 1976. Geologic Map of the Lamar Quadrangle, Colorado and Kansas. U.S Geological Survey Miscellaneous Investigations Series Map I-944, scale 1: 250,000 .

Sharps, J.A., 1980. Geologic Map of the Limon $1^{\circ}$ X $2^{\circ}$ Quadrangle, Colorado and Kansas. U.S. Geological Survey Miscellaneous Investigations Series Map I-1250, scale 1:250,000.
Siems, D.F., 2002. The Determination of 30 Elements in Geological Materials by Energy Dispersive X-ray Fluorescence Spectrometry. U.S. Geological Survey Open-File Report 02-223-U, 11 pp.

Simonett, D.S., 1960. Development and grading of dunes in western Kansas. Ann. Assoc. Am. Geogr. 50, 216-241.

Smith, H.T.U., 1940. Geological studies in southwestern Kansas. Bull. Univ. Kans. 41, $1-212$.

Smith, H.T.U., 1965. Dune morphology and chronology in central and western Nebraska. J. Geol. 73, 557-578.

Smith, R.S.U., 1982. Sand dunes in the North American deserts. In: Bender, G.L. (Ed.), Reference Handbook on the Deserts of North America. Greenwood Press, Westport, Connecticut, pp. 481-524.

Soil Conservation Service and Conservation and Survey Division, University of Nebraska, 1978. General Soil Map of the McCook Area, Nebraska. Map published jointly by the Soil Conservation Service and Conservation and Survey Division, University of Nebraska. Scale, 1:250,000.

Soller, D.R., Reheis, M.C., 2004. Surficial Materials in the Conterminous United States. U.S. Geological Survey Open-File Report OFR-03-275.

Sridhar, V., Loope, D.B., Swinehart, J.B., Mason, J.A., Oglesby, R.J., Rowe, C.M., 2006. Large wind shift on the Great Plains during the Medieval Warm Period. Science 313, 345-347.

Stokes, S., Gaylord, D., 1993. Optical dating of Holocene dune sands in the Ferris dune field, Wyoming. Quat. Sci. Rev. 39, 274-281.

Stokes, S., Swinehart, J.B., 1997. Middle- and late-Holocene dune reactivation in the Nebraska Sand Hills, USA. Holocene 7, 263-272.

Stokes, S., Kocurek, G., Pye, K., Winspear, N.R., 1997. New evidence for the timing of aeolian sand supply to the Algodones dunefield and East Mesa area, southeastern California, U.S.A. Palaeogeogr. Palaeoeclimatol. Palaeocol. 128, 63-75.

Stramel, G.J., Lane, C.W., Hodson, W.G., 1958. Geology and ground-water hydrology of the Ingalls area, Kansas. University of Kansas Publications State Geol. Surv. Kans. Bull. 132, 1-154.

Sweet, M.L., Nielson, J., Havholm, K., Farrelley, J., 1988. Algodones dune field of southeastern California: case history of a migrating modern dune field. Sedimentology 35, 939-952.

Sweet, M.L., Kocurek, G., Havholm, K., 1991. A field guide to the Algodones dunes of southeastern California. In: Walawender, M.J., Hanan, B.B. (Eds.), Geological Excursions in Southern California and Mexico, Guidebook for 1991 Annua Meeting of the Geological Society of America. Department of Geological Sciences, San Diego State University, San Diego, California, pp. 171-185.

Swinehart, J.B., 1990. Wind-blown deposits. In: Bleed, A., Flowerday, C. (Eds.), An Atlas of the Sand Hills. Resource Atlas No. 5a, University of Nebraska-Lincoln, pp. $43-56$.

Swinehart, J.B., Diffendal Jr., R.F., 1990. Geology of the pre-dune strata. In: Bleed, A., Flowerday, C. (Eds.), An Atlas of the Sand Hills. Resource Atlas No. 5a, University of Nebraska-Lincoln, pp. 29-42.

Swinehart, J.B., Loope, D.B., 1992. A giant dune-dammed lake on the North Platte River, Nebraska. Geological Society of America Abstracts with Programs 24, no. 7. A5

Swinehart, J.B., Souders, V.L., DeGraw, H.M., Diffendal Jr., R.F., 1985. Cenozoic paleogeography of western Nebraska. In: Flores, R.M., Kaplan, S.S. (Eds.), Cenozoic Paleogeography of West-central United States, pp. 209-229. Denver, Colorado, Rocky Mountain Section of the Society of Economic Paleontologists and Mineralogists.

Swinehart, J.B., Loope, D., Ponte, M., Mason, J., Helland, P., Kim, N., 1994b. Paleoenvironments of the Nebraska Sand Hills. Society for Sedimentary Geology, Midcontinent Section, Field Trip Guidebook. Lincoln, University of Nebraska, 40 pp.

Swinehart, J.B., Dreeszen, V.H., Richmond, G.M., Tipton, M.J., Bretz, R., Steece, F.V., Hallberg, G.R., Goebel, J.E., 1994a. Quaternary Geologic Map of the Platte River $4^{\circ}$ X $6^{\circ}$ Quadrangle, United States. U.S. Geological Survey Miscellaneous Investigations Series Map I-1420 (NK-14). Scale 1:1,000,000.

Taylor, S.R., 1965. The application of trace element data to problems in petrology. Phys. Chem. Earth 6, 133-213.

Taylor, S.R., Heier, K.S., 1960. The petrological significance of trace element variations in alkali feldspars. In: Barth, T.F.W., Sørensen, H. (Eds.), International Geological Congress, Copenhagen, Part XIV, Proceedings of Section 14, the Granite-gneiss Problem, pp. 47-61.

Tchakerian, V.P., 1991. Late Quaternary aeolian geomorphology of the Dale Lake sand sheet, southern Mojave desert, California. Phys. Geogr. 2, 347-369.

Thornbury, W.D., 1965. Regional Geomorphology of the United States. John Wiley \& Sons, Inc., New York, 609 pp.

Tweto, O., 1979. Geologic Map of Colorado. U.S. Geological Survey, scale 1:500,000.

Van de Kamp, P.C., 1973. Holocene continental sedimentation in the Salton Basin, California: a reconnaissance. Geol. Soc. Am. Bull. 84, 827-848.

Walker, T.R., 1979. Red color in dune sand. In: McKee, E.D. (Ed.), A Study of Global Sand Seas. U.S. Geological Survey Professional Paper 1052, pp. 61-81.

Warren, A., 1976. Morphology and sediments of the Nebraska Sand Hills in relation to Pleistocene winds and the development of eolian bedforms. J. Geol. 84, 685-700.

Warren, A., 2013. Dunes. John Wiley \& Sons, Ltd., Chichester, 219 pp.

Waters, M.R., 1983. Late Holocene lacustrine chronology and archaeology of ancient Lake Cahuilla, California. Quat. Res. 19, 373-387.

Wedepohl, K.H., 1969. The Handbook of Geochemistry, vol. 1. Springer-Verlag, Berlin (442 pp).

Wells, S.G., McFadden, L.D., Schultz, J.D., 1990. Eolian landscape evolution and soil 
formation in the Chaco dune field, southern Colorado Plateau, New Mexico. Geomorphology 3, 517-546.

Westin, F.C., Bannister, D.L., Huron, S.D., 1971. Soil Associations of South Dakota. AES Information Series No. 3. Agricultural Experiment Station, South Dakota State University, Brookings, and U.S. Department of Agriculture Soil Conservation Service, Huron.

White, A.F., Schulz, M.S., Vivit, D.V., Blum, A.E., Stonestrom, D.A., Anderson, S.P., 2008. Chemical weathering of a marine terrace chronosequence, Santa Cruz, California I: Interpreting rates and controls based on soil concentration-depth profiles. Geochim. Cosmochim. Acta 72, 36-68.

White, K., Goudie, A., Parker, A., Al-Farraj, A., 2001. Mapping the geochemistry of the northern Rub' Al Khali using multispectral remote sensing techniques. Earth Surf. Process. Landforms 26, 735-748.

Wilson, E.D., 1960. Geologic Map of Yuma County, Arizona. Arizona Bureau of Mines. University of Arizona scale 1:375,000.

Wilson, I.G., 1973. Ergs. Sediment. Geol. 10, 77-106.

Winspear, N.R., Pye, K., 1995. Sand supply to the Algodones dunefield, south-eastern California, USA. Sedimentology 42, 875-891.

Winspear, N.R., Pye, K., 1996. Textural, geochemical and mineralogical evidence for the sources of aeolian sand in central and southwestern Nebraska, U.S.A.
Sediment. Geol. 101, 85-98.

Wolfe, S.A., Hugenholtz, C.H., 2009. Barchan dunes stabilized under recent climate warming on the northern Great Plains. Geology 37, 1039-1042.

Wolfe, S.A., Muhs, D.R., David, P.P., McGeehin, J.P., 2000. Chronology and geochemistry of late Holocene eolian deposits in the Brandon Sand Hills, Manitoba, Canada. Quat. Int. 67, 61-74.

Wright Jr., H.E., 1970. Vegetational history of the Central Plains. In: Dort Jr., W. Jones Jr., J.K. (Eds.), Pleistocene and Recent Environments of the Central Great Plains. University of Kansas, Department of Geology Special Publication, Lawrence, pp. 157-172.

Yang, X., Zhu, B., White, P.D., 2007. Provenance of aeolian sediment in the Taklamakan Desert of western China, inferred from REE and major-elemental data. Quat. Int. 175, 71-85.

Zimbelman, J.R., Williams, S.H., 2002. Geochemical indicators of separate sources for eolian sands in the eastern Mojave Desert, California, and western Arizona. Geol. Soc. Am. Bull. 114, 490-496.

Zimbelman, J.R., Williams, S.H., Tchakerian, V.P., 1995. Sand transport paths in the Mojave Desert, southwestern United States. In: Tchakerian, V.P. (Ed.), Desert Aeolian Processes. Chapman and Hall, London, pp. 101-129. 